Illinois State University

ISU ReD: Research and eData

Theses and Dissertations

7-1-2014

\title{
We Are Aquin: The Creation of Community and Personal Identity in The Freeport Catholic Schools
}

Sherry Ann Cluver

Illinois State University, sacluver@gmail.com

Follow this and additional works at: https://ir.library.illinoisstate.edu/etd

Part of the Other History Commons, and the United States History Commons

\section{Recommended Citation}

Cluver, Sherry Ann, "We Are Aquin: The Creation of Community and Personal Identity in The Freeport Catholic Schools" (2014). Theses and Dissertations. 212.

https://ir.library.illinoisstate.edu/etd/212

This Thesis is brought to you for free and open access by ISU ReD: Research and eData. It has been accepted for inclusion in Theses and Dissertations by an authorized administrator of ISU ReD: Research and eData. For more information, please contact ISUReD@ilstu.edu. 


\title{
WE ARE AQUIN: THE CREATION OF COMMUNITY AND PERSONAL IDENTITY IN THE FREEPORT CATHOLIC SCHOOLS
}

\author{
Sherry A. Finch Cluver
}

122 Pages

August 2014

Aquin Central Catholic High School, a tiny institution in the rural, Midwestern town of Freeport, Illinois, is a case study unlike the schools from Chicago, Boston, and other large cities highlighted in previous scholarship. Freeport's patterns of schooling in the 1970s and 1980s were largely unaffected by race or "white flight," and the Roman Catholic Diocese of Rockford afforded to its schools a greater than usual degree of local control. Yet, Aquin (founded in 1923) followed the trends of Catholic schools with regard to the Second Vatican Council (1962-1965), assimilation of previously immigrant Catholic families into middle class American social and economic security, and post-war shifts in American culture. While intertwined with themes of faith and academic success, the component of communal and individual identity was a pivotal factor for Catholic school families. Thus, Michael Kammen's Mystic Chords of Memory: The Transformation of Tradition in American Culture (1991) was employed as a conceptual framework in this project to analyze the creation and maintenance of community at Aquin High School. Therein was an environment rich in legends and traditions and conducive to elders enforcing behavioral honor codes. This thesis claims that Aquin was a microcosm of Kammen's paradoxical American identity, managing carefully the 
tension of conflicting values: progress and tradition, the national and the particular, and power and innocence. International in their faith and American in their outlook, the people of Aquin, in the wake of Vatican II and the post-war era, created an empowered, local community that reflected both their changing Catholicism and a shifting national culture. Benefitting from the authoritative leverage of being a private school, Aquin was bound by fewer legal obligations and legislative mandates than were institutions in the public sector. This unique case study, peeling away factors of "white flight" and diocesan control, offers a clear anecdote of what a Catholic school chose to create when allowed particularly great autonomy. Within its intimate, largely middle-class, school environment, Aquin developed successful, college-preparatory, academic training for its students while fostering, also, a modern Catholicism of spiritual development, social justice, and ecumenicalism. The study of Aquin Central Catholic High School provides clear evidence in support of earlier studies that claimed Catholic education facilitated a tension between empowering its students for individual success and demonstrating their ideological commitment to the common good. 
WE ARE AQUIN: THE CREATION OF COMMUNITY AND PERSONAL IDENTITY IN THE FREEPORT CATHOLIC SCHOOLS

\author{
SHERRY A. FINCH CLUVER
}

A Thesis Submitted in Partial Fulfillment of the Requirements for the Degree of

MASTER OF SCIENCE

Department of History

ILLINOIS STATE UNIVERSITY 
(C) 2014 Sherry A. Finch Cluver 
WE ARE AQUIN: THE CREATION OF COMMUNITY AND PERSONAL IDENTITY IN THE FREEPORT CATHOLIC SCHOOLS

SHERRY A. FINCH CLUVER

COMMITTEE MEMBERS:

Richard Hughes

Monica Cousins Noraian 


\section{ACKNOWLEDGMENTS}

A large number of people assisted patiently with my efforts on this project, and I thank Dr. Richard Hughes for his primary guidance as my thesis chair and Dr. Monica Cousins Noraian for her advice as a member of my thesis committee, Dr. Andrew Hartman for his early encouragement, Dr. Delgado, Alice Magginis, Kathy Spence, and Sarah Dick for their counsel regarding the IRB process and copyright regulations, and Sharon Foiles for years of kindness and prompt, accurate answers about all things related to the master's in History. I am indebted to the generosity of Mike Cieslak, Sue Murray, and Sister Joella Miller for their insightful perspectives and research assistance with regard to the Rockford Diocese. Additionally, I am grateful to Father David Beauvais, Mindy Borgmann, George Buss, Rich Chang, Kay Hadjokas, Cathy Finch, Edward Finch, Bill Pospischil, Kathy Runte, Tim Smith, and Adam Talbert for their candid interviews and generosity with their time and to Barb Curry, Laura Diemer, Connie Gogel, and Mary Ann Pontius for their data gathering and archiving of Aquin's artifacts. In appreciation for her accounting expertise and help with reading some complicated financial statements, I thank Andrea Weedman, and thanks goes, also, to Deanna Wiist for her pivotal suggestion to explore the work of Michael Kammen. I would be remiss not to recognize all of my family and friends for their monumental tolerance of the hours I spent in my home office and my overall preoccupation with this work. In particular, I acknowledge the sacrifice made by my husband, Chad, and my children: Anna, Hunter, Jameson, and Baylor. Lastly, I must give great credit to my father for his repeated 
assistance with research, my friend, Jean, for her regular, gracious, perspective-giving advice, and my sister, Remy, for being my brain when I could no longer "see" where I was going with this work. This is only the initial journey into the world of scholarship, but for now, loved ones, the "T-word" has been completed.

S.A.F.C. 


\section{CONTENTS}

ACKNOWLEDGMENTS

CONTENTS

CHAPTER

I. THE RESEARCH QUESTION AND HISTORIOGRAPHY 1

II. WE ARE AQUIN: A CONTEXTUALIZED HISTORY OF AQUIN CENTRAL CATHOLIC HIGH SCHOOL PRIOR TO 1970.

III. SURVIVING THE 1970s AND 1980s, THE HIERARCHICAL PERSPECTIVE

IV. SURVIVING THE 1970s AND 1980s, THE VIEW FROM THE SUBALTERN, PART I

V. SURVIVING THE 1970S AND 1980S, THE VIEW FROM THE SUBALTERN, PART II

VI. WHO DID "WE" BECOME, THE VIABILITY AND CHARACTER OF AQUIN IN THE TWENTY-FIRST CENTURY 


\section{CHAPTER I}

\section{THE RESEARCH QUESTION AND HISTORIOGRAPHY}

School professionals and, consequently, families with children in American schools face initiative after initiative set in motion by politicos making "good" on campaign promises to assure that no longer will any child be left behind. ${ }^{1}$ From the No Child Left Behind (NCLB) legislation to the Race to the Top with the Danielson Model and the Common Core State Standards, there is presently a strong movement toward centralized control of America's schools. Simultaneously, and perhaps as a consequence, there is an increase in the number of children being home-schooled, attending charter schools, and enrolling in either nondenominational or sectarian religous institutions. The issues facing education in America today make relevant a look at the history of our system of education, and specifically, a study of locally-run Catholic schools which have been a vital component of the educational landscape of America.

After exploring the contours of scholarly contributions to the study of Catholic education by way of an historiographical essay, we shall embark on a case study to demonstrate the ways in which a rural, Catholic high school in the northwest corner of Illinois survived declining enrollment and financial hardships in the 1970s and 1980s. Aquin Central Catholic High School remained open, and its graduates successful, in the

\footnotetext{
${ }^{1}$ Wayne J. Urban and Jennings L. Wagoner, Jr., American Education from Colonial times to the Present. (New York: The Crossroad Publishing Company, 1996), 356-357.
} 
post-war era and period following the Second Vatican Council, when many Catholic schools closed their doors. What were the reasons for the resilience and success of Aquin, and was it as unique as it proclaimed itself to be? What answers might it hold for other schools and educators - Catholic or otherwise? Studying the adaptations undertaken in the past should prove fruitful, for "historians do more than reconstruct the past in new ways. They transform the possibilities in . . . (the) present and future." The historiography on Catholic education metes out a multitude of case studies from major cities, from Boston to Chicago to Los Angeles, that make clear that the laity as foundation for each Catholic school created an environment predicated on the particular factors and the characters that comprised each school community. Additionally, as Aquin was a tiny school forging on tenaciously from within an unassuming eighty-eight yearold structure in the older portion of a mid-sized, Midwestern town, its history had been shaped differently than the parochial schools in urban centers or suburban areas . ${ }^{3}$

There are, however, common threads running through much of the historiography of Catholic education: faith, success, and identity. Clearly, the intertwined strands of change in the American culture of the latter half of the twentieth century and the seismic shake-up in the Roman Catholic Church via the Second Vatican Council (1962-1965) created a shift for Catholic schools. ${ }^{4}$ The sixteen documents created by "Vatican II" called for a "positive engagement with contemporary society," which empowered the

\footnotetext{
${ }^{2}$ Monica Cousins Noraian, Women's Rights, Racial Segregation and Education from 1850-1920: the Case of Sarah Raymond, the First Female Superintendent. (New York: Palgrave MacMillan, 2009), 2.

${ }^{3}$ The objective, "outsider's" perspective on the AHS school building being modest in appearance was courtesy of Mike Cieslak of the Diocese of Rockford, interview by author, February 25, 2014.

${ }^{4}$ Colleen McDannell, The Spirit of Vatican II: A History of Catholic Reform in America. (New York: Basic Books, 2011), ix-xii.
} 
laity and encouraged ecumenicalism. ${ }^{5}$ Whereas the faith emphasis had been previously aimed at the preservation of the Catholic religion, faith became newly focused on personal spiritual development and social justice; this change was driven by Vatican II, but was not independent of cultural change. ${ }^{6}$ Success of nineteenth and early twentieth century Catholic schools was attained when Catholic immigrants assimilated into American culture and achieved economic security and improved social status. ${ }^{7}$ Thus, this success in its earlier mission called for increased academic rigor in the schools and expectations that they keep pace with the post-war developments in the public schools. Catholic parents wanted assurance that their students would achieve academically and be prepared for future success. Finally, the identity of Catholics as "ethnic" or "ghetto" Catholics shifted, also due to the afore-mentioned success, to a powerful sense of identity as members of a particular Catholic school community. ${ }^{8}$ This strong identification of one's self as a member of a tight-knit, local network is, arguably, the most essential benefit offered by Catholic schools; it does not, however, exist without offering, also, spiritual development and academic achievement.

Historian James M. O’Toole, author of From Generation to Generation, provided a detailed and contextualized chronological narrative of the Archdiocese of Boston, written in 1983, when O'Toole was the archdiocese' archivist. While still archivist, he

\footnotetext{
${ }^{5}$ Ibid., 73.

${ }^{6}$ John T. McGreevy, Catholicism and American Freedom; A History. (New York: W.W. Norton \& Company, 2003), 295; James M. O’Toole, The Faithful: A History of Catholics in America. (Cambridge: The Belknap Press of Harvard University Press, 2008), 3.

${ }^{7}$ Robert E. Sullivan and James M. O'Toole, Catholic Boston: Studies in Religion and Community 1870-1970. (Boston: Roman Catholic Archbishop of Boston, 1985), 5.

${ }^{8}$ Andrew M. Greeley and Peter H. Rossi, The Education of Catholic Americans. (New York: Anchor Books, Doubleday \& Company, Inc., 1968), 227-229, 234; Anthony S. Bryk, Valerie E. Lee, and Peter B. Holland, Catholic Schools and the Common Good. (Cambridge: Harvard University Press, 1993), 10. Bryk was Professor of Education and Organizational Studies, Lee was Professor of Education, and Holland was Superintendent of Belmont Public Schools.
} 
also edited, alongside Robert E. Sullivan, the 1985 Catholic Boston: Studies in Religion and Community 1870-1970. In this work he analyzed the Catholic school topic after the schools had passed through the historical effects of the 1960s and 1970s. The six thematic essays concerning Catholic parish life in Boston focused particularly on the era and influence of Cardinal William Henry O’Connell (1907-1944) who “took a keen interest in every aspect of Catholic education" yet lead school developments that were largely unimpressive. ${ }^{9}$ In the introduction of Catholic Boston, Thomas H. O'Connor spoke to the shift within Catholicism, "Almost overnight many of the thought processes and value systems of immediately previous generations became nearly as distant as those of earlier centuries" due to the monumental changes in Catholic culture ushered in by the Second Vatican Council, the election of John F. Kennedy, and Sputnik. ${ }^{10}$ Catholics "were moving from a depressed immigrant status in the nineteenth century, when they had little political power, financial stability, or social standing, to a more established position in the twentieth century, when they first achieved a remarkable degree of political success and then began to acquire economic prosperity and social respectability.",11

In The Faithful: A History of Catholics in America (2008), O'Toole gave a broader, sweeping history of American Catholicism, focused on the laity from the colonial era to the early twenty-first century. He asserted "the British cardinal John Henry Newman's wry comment about the laity - that the church would look pretty silly without them - still has an irreducible logic a century and a half after he said it. The story of Catholicism in America must always be the story of these people, the men and

\footnotetext{
${ }^{9}$ Sullivan and O'Toole, 5.

${ }^{10}$ Ibid., 2.

${ }^{11}$ Ibid., 12.
} 
women in the pews."12 Providing an excellent anecdote to demonstrate the shift in the Church, he recounted that at one point in 1964, during dialogue between the special commission of the Vatican deliberating artificial contraception, Patty Crowley, the sole woman on the commission, took to task Spanish priest Father Marcelino Zalba. ${ }^{13}$ (Patty and her husband were included so as to "represent the perspective of married couples.") Father Zalba insisted that if "the condemnation of artificial contraception had been wrong, 'what, then, with the millions we have sent to hell' for disobeying it?" Daring as few women, or laity of either gender, might have prior to the Second Vatican Council, Patty challenged back, "Father Zalba, do you really believe God has carried out all your orders?"14 Certainly, Vatican II empowered Catholics, yet O'Toole reminded that "given the extent of cultural change in American society in the second half of the twentieth century, that well-ordered world (of the pre-council church) probably could not have survived in any case. ${ }^{15}$ He argued further that the Catholic Church influences "other realms of American life" and as such, the history of American Catholics and the contemporary Catholics, themselves, "are a part of the larger conversation that is American life."16 While the Church "often seemed to think that it had escaped history" and seemed always "to be getting bigger and better," "more recently, that has changed."17

Historian John T. McGreevy offered two monographs, one in 1996, Parish Boundaries: The Catholic Encounter with Race in the Twentieth-Century Urban North, and the other, Catholicism and American Freedom: A History in 2003. The scope of the first was from the first World War to the early 1970s, "when the Catholic system of

${ }^{12}$ O'Toole, The Faithful,3.

${ }^{13}$ Ibid., 200.

${ }^{14} \mathrm{Ibid} ., 201$.

${ }^{15}$ Ibid., 265.

${ }^{16}$ Ibid., 10.

${ }^{17}$ Ibid., 4-5. 
parishes and schools first expanded into every section of the northern cities, and then, within the last quarter century, began retreat from what now seemed institutional hubris."18 He claimed that too often American racism had been studied too simplistically, discussing "white racism" or "working class racism" and that, in northern American cities, racism was most profoundly invoked by housing issues of neighborhood identity. ${ }^{19}$ "American Catholics frequently defined their surroundings in religious terms." 20 His claim was that "in the 1960s, two simultaneous events - the civil rights movement and the Second Vatican Council - combined to place the Catholic struggle over race and religion at the center of the nation's cultural turmoil," and "by the decade's conclusion, theological discussion had combined with civil rights marches to produce a church almost unrecognizable to longtime communicants." ${ }^{21}$ Economic security and advancement in social class saw Catholics of the cities moving into suburban zones, which "forced bishops and parishioners to reckon with the scores of almost empty churches, convents, rectories, and auditoriums." 22 "Beset by high maintenance costs on aging physical plants, these parishes are often valiantly supported by small groups of elderly white holdouts and African-American newcomers." ${ }^{23}$ Neighborhoods, and as a result, Catholic schools in northern cities, were redefined.

McGreevy's latter work, Catholicism and American Freedom, focused upon Catholic intellectual life from the mid-nineteenth century to 2003, traversing a sweep of the schooling issues of the 1800s, the Civil War and the issue of slavery, nationalism and

\footnotetext{
18 John T. McGreevy, Parish Boundaries: The Catholic Encounter with Race in the Twentieth-Century Urban North. (Chicago: University of Chicago Press, 1996), 5.

${ }^{19}$ Ibid., 3-4.

20 Ibid.

${ }^{21}$ Ibid., 5.

22 Ibid., 261.

${ }^{23}$ McGreevy, Parish Boundaries, 261.
} 
American freedom, social injustice, and social and moral issues of the twenty-first century. He claimed a shift in Catholicism happened, moving Catholics from an emphasis on "faith in eternal verities" as lead by hierarchy and fed by tradition to an emphasis on the social gospel of "associations and ties with the strangers in our midst" so as to create a bit of Heaven, here and now, on Earth. ${ }^{24}$ In both works McGreevy was consistent in his focus on matters of social justice and the adaptations made by the Catholic Church.

Timoth Walch, director of the Herbert Hoover Presidential Library and editor of the U.S. Catholic Historian, also provided two works for our analysis. His 1996 Parish School: American Catholic Parochial Education from Colonial Times to the Present argued that the "unwavering belief that the education of children is a primary responsibility of the family and the church, not the government" was a view held by "most American citizens" through the mid-1800s and was a paradigm held, still in the 1990s, by families dedicated to American Catholic schools. ${ }^{25}$ The preservation of the Catholic faith by way of Catholic schools, a shift in the schools' focus from assimilation to educational achievement, and the importance of community are three themes emphasized by Walch.

Urban Catholic Education: Tales of Twelve Cities (2010) is a series of twelve essays edited by Walch and Thomas C. Hunt; each written by a different scholar and focused on a different American city. The historians' central claim was "the importance of place: each local church is different, shaped by its unique combination of history,

\footnotetext{
${ }^{24}$ McGreevy, Catholicism and American Freedom, 295.

25 Timothy Walch, Parish School: American Catholic Parochial Education from Colonial Times to the Present. (New York: The Crossroad Publishing Company, 1996), 1.
} 
communities, cultures, and leaders. ${ }^{26}$ The essay by social historian Ellen Skerrett shown a light on "Windy City Catholicism: Catholic Education in Chicago." She explicated Archbishop George Mundelein's (1916-1939) unification of the curriculum of the city's parochial schools and his "separate but equal" approach to serving AfricanAmerican Catholic school children, as well as Cardinal Samuel Stritch's (1940-1958) proclamation that Catholics ought to "regard (inner city) neighborhood conservation as a pastoral duty as well as a civic responsibility." ${ }^{, 27}$ Additionally, she highlighted Archbishop Albert Gregory Meyer's (1958-1965) public directive "that pastors were to . . . 'ensure that all our Catholics of the Negro race are integrated into the complete life of the church." ${ }^{28}$ Her specific contribution, therefore, was that she traced the shift of Catholic identity with regard to ethnicity and race as projected by the church hierarchy in Chicago.

Moving forward, this essay segues from a structure based on authors and their several works to a strictly thematic organization. Thus, the theme most obvious when discussing anything Catholic, a shift in faith from preservation of religion to spiritual development and social justice, will be addressed first, followed by a more brief analysis of the shift from success in assimilation and economic security to that of achievement in academics and preparation for future success. The essay concludes with the third theme, which is most central to the argument of this paper -- the shift in identity for some Catholics from that of a specific immigrant ethnicity or generalized "ghetto" collective to that of members of a particular Catholic school community.

\footnotetext{
${ }^{26}$ Walch, $x$.

${ }^{27}$ Ibid., 216-218.

${ }^{28}$ Ibid.
} 
Faith

O’Toole spoke to the early need of serving Catholics and protecting Catholic children in From Generation to Generation as he recalled the establishment of the Boston diocese in 1808 when "Catholics were so widely scattered around New England at the end of the eighteenth century and there were so few priests to minister to them." He also described the moment in 1843 when Bishop Fenwick scripted "a very tough letter to Boston Mayor Martin Brimmer, protesting the use of a history book in the city's public schools which contained a number of overtly anti-Catholic passages." 29 One might argue such need is irrelevant today; however, Most Reverend John B. McDowell (Ph.D. in educational philosophy) contended in his Catholic Schools, Public Education, and American Culture (2000) that government-funded schools encroached upon the Catholicity of students by way of the adoption of a "religion of secularism." first traced the history of both Catholic and public schools in America from the earliest days through the Progressive Era. His remaining chapters, then, had thematic focuses, including parental responsibility, Catholic philosophy and curriculum, and school leaders, and leaders in public education. Additionally, he outlined education-related U.S. Supreme Court decisions from 1925 to 1997, and he "challenged the position expressed by Justice Brennan and maintained by far too many Americans" that education consists "of secular skills and aptitudes which can be effectively taught in public as well as parochial setting(s)."31 He asserted that God and parents, both, are critical elements of effective education. ${ }^{32}$ His central claim was that "a refusal to permit religious exercises

\footnotetext{
${ }^{29}$ James M. O'Toole, From Generation to Generation. (Boston: Daughers of Saint Paul, 1983), $16,31$.

${ }^{30}$ Reverend John B. McDowell, Catholic Schools, Public Education, and American Culture. (Huntingdon, IN: Our Sunday Visitor Publishing Division, 2000), 148.

${ }^{31}$ McDowell, xiii-xiv.

32 Ibid.
} 
(in government schools) is seen, not as the realization of state neutrality, but rather as the establishment of a religion of secularism."33 McDowell's was an exercise in a profoundly different conceptualization of public schools, decrying not simply the Common School days of anti-Catholicism and lack of access to public funds for Catholic schools, but a refutation that contemporary public schools were adequate or neutral. The author of this thesis argues here, in response, that he is on a slippery slope by going so far as to claim that public schools are "often even directly and bluntly teaching the learner that the religious aspects of life are not worth their time."34 Despite his clear bias against secular, public schools, his description of the importance of both faith and identity within the Catholic schools is supported by the other sources within this scholarly dialogue. Thus, his work provides valuable evidence for particular themes within the Catholic schools that will be detailed in later chapters.

Rev. Peter M. J. Stravinskas harkened to the earliest days of Catholic schools when the school leaders fought widely for federal funds for denominational schools. His Constitutional Rights and Religious Prejudice: Catholic Education as the Battleground (2009) was originally published as a doctoral dissertation in 1981, during the time of President Reagan’s Administration when “talk about educational choice, tuition tax credits and vouchers was very much in the air," and such an argument again became relevant precisely because those initiatives did "not progress significantly." ${ }^{35} \mathrm{He}$ argued for freedom of choice in education and that if such choice was to be a freedom for all families, federal support must be given to nonpublic schools. He asserted that "the

\footnotetext{
33 Ibid., 148.

34 Ibid., 149.

${ }^{35}$ Reverend Peter J. Stravinskas, Constitutional Rights and Religious Prejudice: Catholic Education as the Battleground. (Pine Beach, New Jersey: Newman House Press, 2009), 11.
} 
(increased) presence of other denominations in the educational mix" will further decrease any "historical anti-Catholic dimension" in the dialogue, and thus, focus can be given to "more substantial issues." ${ }^{, 36} \mathrm{He}$ contended that of central importance is the "elimination of an unhealthy monopoly" that he argued public schools held. ${ }^{37}$ In supporting his claim, Stravinskas provided historical, legal, sociological, philosophical, and sociological analyses with the central focus being that of the constitutionality of government support for denominational schools and a desire for a new, thorough dialogue on the matter. ${ }^{38}$ Moreover, his ideology was predicated on the belief that "Catholic schools were critical to the survival of the Catholic Church in the United States," and that the most significant cause of the "decline in American Catholic education" had been financial. ${ }^{39}$ This singular focus upon the preservation of Catholicism by way of the religion's schools runs against the grain of most current scholarship that typically enumerates interdependent assets of such schools.

While Neil G. McCluskey recognized the significance of faith within the Catholic schools, he argued in his 1968 Catholic Education Faces Its Future: The background, present position, and future trends of Catholic education that a shift had occurred from that of religious preservation to that of spiritual development. His overriding argument was the necessity to adapt from conformist "schooling" of Catholic children in the codes of the church to an "education" of students' consciences and reasoning so as to better prepare Catholics for effectiveness in an ecumenical world. ${ }^{40}$ He predicted "that the question of the relation of the publicly-supported school" to the "church-related school"

\footnotetext{
${ }^{36}$ Ibid., 12.

37 Ibid.

38 Ibid., 18.

39 Ibid., 15.

${ }^{40}$ Neil G. McCluskey, S.J., Catholic Education Faces Its Future: The Background, Present Position, and Future Trends of Catholic Education. (New York: Doubleday \& Company, Inc., 1969), 18.
} 
will "be approached in a more sophisticated and socially realistic manner." ${ }^{\text {"11 }}$ McCluskey provided a well-articulated chapter of apologetics, defending the patriotic and civicminded nature of American Catholic schools. ${ }^{42}$ The aim of this work was to propose solutions for the problems facing Catholic education as they were defined in the late 1960s when "Catholic education hover(ed) on the brink of its greatest challenge." ${ }^{43}$ Like Stravinskas, McCluskey addressed the financial threat faced by the Catholic schools. After providing a survey of the history of Catholic education in America, he delved into analytical themes relevant to the ideology of Catholic schools, the hierarchical "establishment" of the church, the laity, and public education. This work contributed a self-deprecating recognition of over-reaching confidence of Catholics with regard to the success of their schools in the 1950s and 1960s when enrollments were booming: "Behind the statistical façade there was security, and with confidence we looked ahead to more of the same. ${ }^{, 44}$ McCluskey set forth an argument to the entire American public that the demise of Catholic schools would place an unbearable "burden" on already struggling public schools, and thus, to avert a fiscal trauma to all, governments could and should "afford nonpublic education a measure of support, within strict constitutional limitations, sufficient to enable it to continue to render its public service." ${ }^{45}$ Redirecting back to the matter of faith, McCluskey argued that the diminishing enrollment and resultant financial strain experienced by the schools necessitated a new paradigm - that the "new house of Catholic education is going to be more compact and will be put to better use," with

\footnotetext{
${ }^{41} \mathrm{Ibid}$.

42 Ibid.

${ }^{43}$ Ibid.

${ }^{44}$ McCluskey, 17.

${ }^{45}$ Ibid., 285.
} 
spiritual training and social justice aims. ${ }^{46}$ Like Walch, he defended the efforts of Catholic schools to welcome "Negro" students, including the majority of whom were not Catholic. ${ }^{47}$ In a similarly updated framework, McCluskey spoke to the ecumenical nature of the Vatican II church. Unlike McDowell, McCluskey recognized that public schools did, indeed, retain some "residual religious items" and that they did teach "about religious values" (observances of religious holidays, semi-religious theater productions, etc). ${ }^{48}$

George Nauman Shuster, a scholar of humanities and social sciences, provided pragmatic ideas based on the data of previous scholarship, notably the work of Sociologist Andrew Greeley. ${ }^{49}$ Referring to the change in Catholic schools in the 1960s and 1970s, Shuster claimed "the world began when the Second Vatican Council ended."50 In his 1967 work, Catholic Education in a Changing World, his prominent claim was that the most essential good imbued in students of Catholic schools was spiritual development: "The function of education is no longer to protect (the student's) conscience by laying down a series of rules . . . (it) is, rather, to be steeled through a constant process of asking questions and finding answers, of accepting tasks or rejecting them." ${ }^{, 51}$ He made clear that this meant not only a mentoring of internal spiritual development, but also that of social justice -- "our obligation is to know our Negro fellow citizens better than many of us used to know the ancient Romans," because "today we all know that what happens . . . in South Chicago will pretty much tell the story of human

\footnotetext{
46 Ibid., 20.

47 Ibid.

48 Ibid., 275.

${ }^{49}$ George Nauman Shuster, Catholic Education in a Changing World. (Chicago: Holt, Rinehart and Winston, 1967), ix.

50 Ibid.

51 Ibid., 2.
} 
rights in the United States." ${ }^{, 52}$ He underscored the importance of "every act of kindness, each hour of effective counseling" and that "it is at least highly probable" that "maintaining institutions in the inner city" is " a contribution to the common good" so long as services are "ethically dedicated." 53 This notion was reiterated by Anthony S. Bryk, Valerie E. Lee, and Peter B. Holland in their 1993 Catholic Schools and the Common Good. ${ }^{54}$ The authors outlined the worthy aim of "ideology that directs institutional action toward social justice in an ecumenical and multicultural world." ${ }^{, 55}$ Finally, the brief 1985 A History of United States Catholic Schooling, by Father Harold A. Buetow, made clear that "there is no such thing as 'private' school. By its nature, every school takes its students from the public and returns them, for good or for ill, to the public." $" 56$ This applies both to the nature of the spirituality taught to students in Catholic schools as well as their preparedness to contribute successfully to their communities. Arguing primarily from a faith platform, clerical scholars McDowell, Stranvinskas, and Buetow share a defensive approach to justifying government support for Catholic schools.

\section{Success}

The aim of Catholic school success has changed over its long history, from the goal of the assimilation of immigrant Catholics into their new, American communities and gaining economic security to more recent times, when success was measured by academic achievement and preparedness for future success. Hunt and Walch's Urban

\footnotetext{
52 Ibid., 3.

53 Ibid., 227.

${ }^{54}$ Bryk, Lee, and Holland, 10.

55 Ibid.

${ }^{56}$ Father Harold A. Buetow, J.D., Ph.D. A History of United States Catholic Schooling. NCEA Keynotes Series no. 2 (Washington, DC: National Catholic Educational Association, 1985), 5.
} 
Catholic Education suggested that the early impassioned establishment and maintenance of Catholic schools was "not just about memory" and preservation of immigrant Catholic culture;" rather, it was for "new aspirations" and "economic security." ${ }^{57}$ In terms of such assimilation, O'Toole reminded in The Faithful that Catholics "were unmatched in their political loyalty" to the United States, joining "the armed forces in numbers higher than their proportion of the population and filled their churches with American flags." ${ }^{58}$ Catholics in America had effectively "cemented their position in the middle class" by the 1930s. ${ }^{59}$ Catholic veterans of World War II benefited from the G.I. Bill alongside nonCatholic veterans, and as a result "secured places in the white-collar workforce." Contrary to the focus on "anti-Catholic bigotry" in many histories of American Catholicism, O'Toole qualified such truth with the perspective that "public perceptions of Catholicism" as portrayed in mass media "have been mostly benign.." ${ }^{\prime 1} \mathrm{He}$ credited this relative acceptance largely to the social service institutions administered by Catholics and financed generously and specifically by those "who were often least able to afford it" all "without any expectation" of religious conversion by the diverse people who benefitted from their services. ${ }^{62}$ The immigrant Catholics of the nineteenth century and their descendants were largely assimilated into American culture by the early twentieth century.

In Sullivan and O'Toole's Studies in Religion and Community (1985), James W. Sanders' essay, "Catholics and the School Question in Boston," emphasized that

\footnotetext{
${ }^{57}$ Thomas C. Hunt and Timothy Walch, Urban Catholic Education: Tales of Twelve American Cities. (Notre Dame, Indiana: Alliance for Catholic Education Press, 2010), $x$.

${ }^{58}$ O'Toole, The Faithful, 7.

${ }^{59}$ Ibid., 193.

${ }^{60} \mathrm{lbid}$.

${ }^{61}$ Ibid., 8.

${ }^{62}$ Ibid.
} 
Boston's Catholic schools did not offer much in the way of academic rigor relative to their public school counterparts. ${ }^{63}$ The period of study, however, was the first half of the twentieth century, prior to the great shifts in Catholic education, and that period was approaching a metaphorical plateau at which assimilation had been largely achieved, yet academic rigor had not yet been improved, generally. On this point Bryk, Lee, and Holland's work brought to light the educational reforms of the Progressive Era and increased use of technology and rigor in math and science in the period to follow; they underscored that the Catholic schools of the 1990s were taking the lead in facilitating success for American youth, including those otherwise deemed disadvantaged. In addition to the benefits of a contracted curriculum and one academic track for all students, Catholic schools benefited public school administrators by offering a keen understanding of the way in which "distinctive features" of Catholic high schools "combine to form supportive social environments that promote academic achievement for a broad cross section of students." ${ }^{64}$ School climate was a key to success.

\section{Identity}

Whereas immigrants traditionally lived within their own ethnic subcultures as frequently as was possible, the establishment of "national churches" (the "German" parish or "Italian" church) during the high tide of Catholic immigration from Europe was commonplace. As evidenced in O'Toole's From Generation to Generation, ethnic patterns in neighborhoods, and even in particular cities was notable: "The Church in the Boston Archdiocese has always been so heavily Irish that the activities and contributions

\footnotetext{
${ }^{63}$ Sullivan and O'Toole, 5.

${ }^{64}$ Bryk, Lee, and Holland, ix.
} 
of other ethnic groups often (went) unrecognized." ${ }^{\circ 5}$ Yet, it is easy not to place too heavy a blame on immigrants for creating such enclaves, because "the strain of transition (from the "old country")" also "brought with it the struggle for identity -both as individuals and as a community.,

Sociologists Andrew M. Greeley and Peter H. Rossi's The Education of Catholic Americans (1968) lacked the awareness that was made clear by McCluskey. Their naivete was analogous to that of the Antebellum South in which there was a certain obliviousness to the significant upending about to occur. They wrote "there (was) nothing in (their) data to indicate that the expansion" of Catholic schools would "be reversed," and that the system, "which (involved) one out of every seven school children in our republic," was deemed to be the sort "that does not go out of business, either all at once or gradually." ${ }^{67}$ Greeley and Rossi had, at least, identified the need for a study of Catholic schools in America to assess religiosity, academic preparation, and future economic and social success of Catholic school students as well as the status and prognosis of Catholic schools. Catholic schools have, indeed, decreased gradually, but proved adaptable enough so as not to disappear entirely. In that regard, Greeley and Rossi were not completely incorrect.

McGreevy, however, critiqued the neighborhood boundaries and the resultant post-war racial discrimination, noting that this dynamic "displayed the frailty of the line between community and fortress. ${ }^{, 68}$ During the mid-twentieth century, when many Catholics had been assimilated to American culture for more than a generation, issues of

\footnotetext{
${ }^{65}$ O'Toole, From Generation to Generation, 169.

${ }^{66}$ Sullivan and O'Toole, 12.

${ }^{67}$ Greeley and Rossi, 2.

${ }^{68}$ McGreevy, Parish Boundaries, 264.
} 
association changed to concern about race, and amid additional changes of the deindustrialization of the economy and altering expectations of gender roles, turmoil was in the air. In The Faithful, O'Toole provided as anecdote the response of a white Catholic in Cicero, Illinois in 1967 when faced with racial integration in his formerly Italian neighborhood -- "We'll rebel.",99 A fearful recoiling to one's zone of comfort was the typical human response, yet looking outward so as to welcome in others was essential for the church. O'Toole counseled that "History is like our own individual memory: without it, we would be lost," and it is most at times of change that such a connection can provide firm footing from which to respond with agility. ${ }^{70}$

Greeley and Rossi reported that the strongest influence on adult Catholic behavior was seen in students who remained within Catholic education through college, and the rating of "enlightened social attitudes was (only) slightly higher for those who went to Catholic high schools." ${ }^{, 71}$ There was "no evidence that Catholic schools have been necessary for the survival of American Catholicism," but there was a significant "relationship between" Catholic schools and "academic commitment" due, in part, to the positive effect of "emotional security" found within that setting. ${ }^{72}$ Similarly, Bryk, Lee, \& Holland supported the assertion of identity as critical in achievement and they noted that the school culture "model(ed) a family atmosphere.,"73 McCluskey concurred that the great value of Catholic education was that it put at the heart of the process the local (parental) control of their children's education, while recognizing the necessary

\footnotetext{
${ }^{69}$ O'Toole, The Faithful, 259.

${ }^{70}$ Ibid., 9.

${ }^{71}$ Greeley and Rossi, 227-229, 234.

72 Ibid.

${ }^{73}$ Bryk, Lee, and Holland, 10.
} 
attunement to advances in academic methods in the public sector. ${ }^{74}$ His conclusion connected directly with the era at the heart of this thesis - the 1970s and 1980s, and McCluskey's concluding chapter provided interesting context for the administrative decisions of Aquin High School.

To this rich history, this thesis aims to add a relevant case study of a school peculiar from those exemplified in other works. In tandem with the scholarship already explicated, additional, specialized monographs will provide further historic context for the primary source documents from the archives of Aquin Central Catholic High School and The Diocese of Rockford. The heart of this study, however, lies in the social history of Aquin, and thus, oral history interviews will provide an intimate picture of the character of the school. Situated a bit over one hundred miles from Chicago, Aquin was affected in only the most indirect of ways by the Windy City, not to mention Boston. Aquin's story unfolded differently, and the cultural issues of racial diversity and school desegregation were largely irrelevant to schooling patterns in Freeport. Because Freeport offered a large, public high school, known for solid academics and a wider array of course offerings and extracurricular activities than what was available to the "Aquin Bulldogs," it was unlikely that the motive for the dogged commitment of Aquin families to their school was academic preparation. (Although, a failure of Aquin to provide adequate instruction would diminish parental investment.) Matters of faith were, indeed, of consequence, as the research to follow points to high levels of Catholicity in the Aquin school day. Yet, the most compelling evidence of this project makes clear the central theme for Aquin's resilience and the achievement of its students was the sense of personal identity derived from membership in a strong school community. Aquin was

\footnotetext{
${ }^{74}$ McCluskey, 25-26.
} 
an intimate family forged and maintained by the "elbow grease" of its members who perceived their school community as an underdog fiercely proud of what they accomplished with few resources. O'Toole wrote that "The story of Catholicism in America must always be the story" of the laity, "the men and women in the pews," and this thesis contends that should include the men and women in the schools. ${ }^{75}$ McDowell would agree, as he argued that "God and parents" were the core of "effective education." 76 The diocesan hierarchy was central to the survival of Aquin, but the school's laity were the key to its success.

While McGreevy provided an excellent survey of American Catholicism and Urban and Walch the same of American education, Greeley, as well as Hunt and Walch, offered insights specific to the sense of identity found within Catholic school communities. Furthermore, the historiographic analysis included O'Toole's suggestion that history and memory are key anchors for humanity, and this thesis introduces to the dialogue, here, the work of Michael Kammen - Mystic Chords of Memory: the Transformation of Tradition in American Culture -- as a novel lens with which to analyze Catholic schools, and Aquin Catholic High School, in particular. ${ }^{77}$ While the concluding chapter will connect this study to the broader question of American education and local control, first, this research will effectively explicate the ways in which Aquin Central Catholic High School epitomized the need in America to reconcile what Kammen identified as conflicting American values of progress and tradition. ${ }^{78}$ The members of the Aquin school community were not necessarily more in need of tradition and a sense of

\footnotetext{
${ }^{75}$ O'Toole, The Faithful, 3.

${ }^{76}$ McDowell, xiii-xiv.

${ }^{77}$ Michael Kammen, Mystic Chords of Memory: the Transformation of Tradition in American Culture. (New York: Vintage Books A Division of Random House, Inc., 1991).

78 Ibid., 702.
} 
"place" than were other Freeporters, but the Aquin environment was more conducive to the creation and maintenance of a powerful collective memory. The small size and private nature of Aquin created a tight-knit community with strong, internal school spirit and emphasis on traditions and legends that created an inward-looking, tribal subculture. This micro-community provided the basis for individual fortitude born of the group's collective identity, and these were the roots that empowered Aquin's students for successful academic and career outcomes. However, the Catholic faith, which imbibed the traditions with a particular ritual flavor, also called Aquin students to have an outward-looking lens of social justice. It was the powerful combination of "roots" and "wings" Aquin provided to students that was the schools' most significant outcome. Why could this environment evolve at places like this middle-class, Catholic school in a seemingly typical, Midwestern town?

To traverse the terrain of this project with clarity, we undertake in Chapter 2 a concise, contextualized history of Aquin Central Catholic High School from its creation in 1923 to approximately 1970, when the initial impact of American cultural change and the Second Vatican Council had made their way through Freeport. Chapter 3 will address the research question regarding Aquin's resilience through the challenges of the 1970s and 1980s from the perspective of the diocesan hierarchy and address factors beyond the direct control of Aquin. The subaltern view on the same target era will be set forth, also thematically, in Chapters 4 and 5, and it is here we visit with members of this small community and apply Kammen's tension beween tradition and progress in analysis of Aquin's subculture. Chapter 6 will consider the viability and character of Aquin in the twenty-first century followed by a reflective synopsis of the ways in which Aquin's traits, 
trends, and trajectory may be useful consideration for institutions, Catholic and otherwise, facing today's currents of change. 


\section{CHAPTER II}

\section{WE ARE AQUIN: A CONTEXTUALIZED HISTORY OF AQUIN CENTRAL CATHOLIC HIGH SCHOOL PRIOR TO 1970}

The story of Catholic education, according to Walch, intensified in the latter half of the nineteenth century with the "millions of new immigrants from Europe . . . (and as) the majority of these new arrivals were poor and Catholic, the American church was the primary source of their support, both spiritual and corporal." ${ }^{\text {79 }}$ Typically in America, religion and ethnic culture formed easily a mutually reinforced, blended subculture of ethnic Catholicism, and the Catholic schools "reflected the goals, aspirations, and even the prejudices and fears of neighborhood Catholics." ${ }^{80}$ As "parents had a sense of involvement in these (national parish) schools," each was dominated typically by a particular immigrant ethnicity. ${ }^{81}$ German Catholics, in particular, tended to desire Catholic schools in America's heartland as a means to preserve "heim and kirche" (home and church). ${ }^{82}$ German and Irish residents of Freeport, Illinois, however, erected a "joint congregation" of St. Mary's church in $1846 .{ }^{83}$ Eighteen years after the establishment of St. Mary's, the Germans, indeed, broke off to build St. Joseph's church.

\footnotetext{
${ }^{79}$ Walch, 67.

${ }^{80}$ McGreevy, Catholicism and American Freedom, 4.

${ }^{81} \mathrm{Ibid}$.

${ }^{82}$ Walch, 51.

${ }^{83}$ Golden Jubilee Souvenir: The History of Catholicity in Stephenson County, IL. (1896), 34, 93.
} 
Decades later, in 1898, St. Mary's Irish were joined by an influx of Italians, many of whom worked the railroad alongside them. ${ }^{84}$

The common experiential piety of Catholics' devotions, apparitions, and miracles emphasized the supernatural to a degree seemingly superstitious to non-Catholics, and therefore, viewed by some Americans as a potential threat to things scientific, rational, and appropriately liberal for the times. ${ }^{85}$ From the large number of Catholic immigrants to the global reach of the Pope, the Roman Catholic Church and her members were often viewed as a foreign threat. In the Midwest, however, Catholics seemed to have had a less contentious go at building their new lives in America than did Catholics elsewhere in the country. "Constitut(ing) more than half the population of Midwestern cities," "providing cheap dependable labor," and running needed institutions, such as schools and hospitals, Catholics found relatively "insignificant" levels of nativist opposition to their presence. ${ }^{86}$

In the Midwest, "where common schools were few in number and overcrowded," Catholic schools "were often praised as important supplements to public education." When it was agreed on August 19, 1923 "to open the high school at the Regular [sic] school day," the project originally named "Freeport Catholic Community High School" was established. ${ }^{88}$ In this Illinois town of approximately 20,000 people, the seventythree-year-old public high school averaged graduating classes around one hundred twenty

\footnotetext{
${ }^{84}$ Patricia Carroll. The History of St. Mary's Catholic Church, Freeport, Illinois: 150 Years of Faith 18461996. (Freeport: Wagner Printing, Co., 1996), 67; Golden Jubilee Souvenir, 176.

${ }^{85}$ Walch, 12, 25, 99.

86 Ibid., 49.

${ }^{87}$ Ibid., 4, 38.

${ }^{88}$ Minutes of Meetings of Freeport Catholic High School, August 19, 1923, Aquin Central Catholic High School Papers, Private collection.
} 
students. ${ }^{89}$ Because the public high school constructed a new building in 1925, it is possible that their old quarters had become cramped. ${ }^{90}$ However, one might also speculate the motive for the establishment of the Catholic high school was that of closing ranks within their Catholic subculture. Yet, those same meeting minutes also reported that those in attendance "voted at this meeting to charge tuition for $\$ 25.00$ per year and to admit non Catholic for same fee." $"$ (The name of the school was changed to "Aquin High School" the following year. ${ }^{92}$ ) While open to Catholic-Protestant interaction in the school day, the founders of Aquin were, perhaps, interested more purely in the preservation of the faith in their children. Catholic leaders in the United States during the previous century typically took issue with the public schools for "usurp(ing) the traditional role of the church," concerned that the curriculum "included heavy doses of Protestant instruction and anti-Catholic propaganda."93 "The movement to establish Catholic schools was, above all else, an effort to prevent Catholic children from abandoning their religious faith."94 This may bear some truth for Freeport; yet, the primary sources do not suggest any significant contentiousness between Freeport Catholics and non-Catholics in the later era when the Catholic high school was established nor any obvious complaints against the public high school. It seemed in this 1923 small, Midwestern town that the nineteenth century ideologies of Catholic

\footnotetext{
${ }^{89}$ Minutes of Meetings of Freeport Catholic High School; Census Quick Facts, http://quickfacts.census. gov/ (accessed March 17, 2014); History of Freeport High School, Freeport High School, www.freeportschooldistrict.com/domain/108 (accessed March 17, 2014).

90 History of Freeport High School.

${ }^{91}$ Minutes of Meetings.

92 "Aquin History," Aquin Catholic Schools. http://www.aquinschools.org/history.cfm (accessed March 18, 2014).

${ }^{93}$ Walch, 2.

94 Ibid.
} 
defensiveness were largely a thing of the past and the Progressive Era was clearly underway.

America began more formalized bureaucratic control and maintenance of public education, which, in turn, informed those administering the Catholic schools. ${ }^{95}$ "Catholic educators at the turn of the century were searching for order in the development of their schools," and Aquin clearly fit the trend, boasting continuous accreditation since its third year of operation - 1926 - through to today. ${ }^{96}$ The plan for one Catholic high school to serve together all Catholic children in Freeport, whether they came from families of German, Irish, Italian, or other heritages, aligned with the 1916 efforts of Chicago Archbishop George W. Mundelein, who worked to "unify the parochial school curriculum (in the City of Chicago) so that children of different ethnic and racial backgrounds would share a common identity as American Catholics. ${ }^{, 97}$ Such curricular alignment was in step with the national trend for Catholic schools to "cull" from progressive education reformers those "human sciences or empirical psychology and biology" elements "that were in harmony with Christian teachings."

With many Catholic school facilities bursting at the seams with an overabundance of pupils, it appeared that Catholic education in America was "on (its) way to (a) golden era." ${ }^{99}$ In the mid-twentieth century the number of Catholic school students jumped from two and a half million to four million in a matter of just twenty years. ${ }^{100}$ Indeed, Aquin's enrollment continued to climb from its inception through the first half of the twentieth century, peaking in the early-to-mid 1960s with enrollment averaging around three

\footnotetext{
${ }^{95}$ Urban and Wagoner, 146, 175.

${ }^{96}$ Walch, 100; http://www.aquinschools.org/history.cfm.

${ }^{97}$ Hunt and Walch, Urban Catholic Education, 208.

${ }^{98}$ Walch, 119.

${ }^{99}$ McDowell, 44.

${ }^{100}$ Ibid.
} 
hundred students. ${ }^{101}$ Attempting to keep pace with their schools' growth and with patterns in education, Catholic superintendents across the country "saw to it that relevant state laws were observed," and " they dealt with the appropriate state officials; they kept diocesan programmers informed about the latest trends in education and regularly met with local teachers and administrators to assure that their little section of the vineyard was up to date." 102

Both a branch on the Catholic vine and a piece of the American puzzle, Freeport's parishes and schools were, indeed, connected to and affected by events in the country and world outside the perimeter of their local industries and dairy farms. School opening was "delayed due to the second outbreak of polio" in the fall of 1946, and as a result of the 1962 Cuban missile crisis, "four Cuban children were placed by Rockford Catholic Charities with St. Mary's families and enrolled in (the) parish school."103 (The local history source did not explain why this U.S. fear necessitated Cuban children to live in Illinois.) "On Monday, November 25 (1963)" the "school was closed . . . for a national day of mourning. That evening at 5:30 P.M., a requiem high Mass was offered" for slain Catholic President John F. Kennedy. ${ }^{104}$ World War II introduced a seismic culture shift. While there was pride in the fact that "immigrant Catholic parents (had taken) parish schooling from a few dozen schools in 1820 to nearly ten thousand schools 140 years later (1960)," the noncooperation by many Catholics in interreligious ventures during World War II was embarrassing, and by the post-war era it had become an unavoidable reality that remnants of cloistered behavior would no longer serve well the Catholic

\footnotetext{
${ }^{101}$ School Census Forms, Diocese of Rockford, Aquin Papers.

102 McDowell, 44, 45.

${ }^{103}$ Carroll, 88, 98.

104 Ibid., 99.
} 
population. ${ }^{105}$ It was time for Catholics to assume their place as fully integrated members of American society.

Yet, the twentieth century also brought with it the Cold War era in which "anxious Americans sought renewed sources of security," and "they zealously devoted themselves to the three institutions most capable of serving as a foundation of stability: family, church, and school."106 This was a peculiar tension between personal emotional security and collective nationalism. It was no longer enough for Catholics to be interactive with those outside of their faith, but in the political, psychological, and cultural dynamics of the period, one needed to be both intensely nationalistic and individualistic in a positivist way to be deemed "American enough" by elitist, conservative standards. ${ }^{107}$ Catholics, in their emphasis on "community," were characterized similarly to the progressives as being too socialist. ${ }^{108}$ Episcopalian Minister Bernard Iddings Bell, however, placed Catholics and progressives at the "opposite" ends of the "pole" in their details. ${ }^{109}$ Elite conservatives viewed the progressive ideology of equitable career training and the Catholic value of collective morality as anathema to individual autonomy. ${ }^{110}$ Whereas Russia's successful launch of Sputnik escalated educational focus on science and technology, some Catholic leaders had negative judgments about " too great an emphasis on science and technology and their influence on the American way of life."111 Catholic schools, however, updated

\footnotetext{
${ }^{105}$ Walch, 4; McGreevy, Catholicism and American Freedom, 204-205.

${ }^{106}$ Andrew Hartman, Education and the Cold War: The Battle for the American School. (New York: Palgrave MacMillan, 2008), 91, 97.

107 lbid.

108 Ibid.

109 Ibid.

${ }^{110}$ Hartman, 91, 97.

${ }^{111}$ Urban and Wagoner, 265, 267; McDowell, xiii.
} 
science offerings and built new laboratory facilities for their students after $1960 .{ }^{112}$ Aquin fit this trend, constructing an addition to the high school, equipped with four lecture classrooms, a new gymnasium, band room, cafeteria, and two "modern" science laboratories. It turned out that finances, not ideology, most troubled the Catholic schools. "The most significant educational consequence of Sputnik . . . was the impetus it gave to federal financing of public education."113 Not only did the Catholic schools have to keep pace with the public schools without public moneys, the subsequent increase in federal funding set the stage for a widening gulf between the two systems in terms of financial resources.

Cold War fears and conservative reaction additionally affected schooling in terms of resistance to racial integration. ${ }^{114}$ It was not only the nativist, elite conservatives, however, whose housing choices shifted to the outskirts of cities; "thousands of Catholic families moved to the suburbs after World War II, (and) a similar migration pattern had taken place within Chicago itself, from older parishes to newer residential neighborhoods at the city's edge."115 A variety of factors motivated folks to move, including more green space, new manufacturing facilities for employment, and housing values. "Racism alone is too simple an explanation of the resistance to court-ordered school desegregation," it involved matters of class conflict, “ethnicity and place, or 'turf,' and religion.",116 Whereas "discord between Irish Catholics and African-Americans extended back to before the Civil War" when "the two pariah groups shared competition for jobs at the bottom," there was also the history, not specific to matters of race, of neighborhoods

112 Urban and Wagoner, 265.

113 Ibid, 265.

114 Ibid, 106.

${ }^{115}$ Hunt and Walch, 214.

${ }^{116}$ Ronald P. Formisano, Boston Against Busing: Race, Class, and Ethnicity in the 1960s and 1970s. (Chapel Hill: The University of North Carolina Press, 1991), xi, xii, xiv. 
"mobiliz(ing) intense resistance" to any threat to the subcultures of familiarity. ${ }^{117}$ This typically Catholic response differed in content if not in outcome to that of "a new conservatism predicated on a language of rights, freedoms, and individualism." "118 While this social turmoil gave rise to conservative policy considerations regarding possible tuition vouchers, such federal plans did not come to fruition. White flight, however, appeared not to have affected directly Aquin High School.

While Chicago's black population grew exponentially, race as a factor in school choice in Freeport seemed null. "The African American population of (Chicago) rose from 277,731 in 1940 to 492,265 in 1950 and again to 812,637 in 1960. ."119 "In the 1950s, an average twelve city blocks per month changed from majority-white to majority-black ownership."120 The Brown v. Board of Education U.S. Supreme Court decision of 1954 "helped spark a civil rights movement that galvanized many African Americans into organized political and social action," and Rockford, Illinois, approximately one third of the way from Freeport to Chicago and the second largest city in the state, saw African American riots in reaction to the July 1967 riot in Chicago. ${ }^{121}$ Yet, white flight from Rockford never reached further than Winnebago, IL, located an equidistant twenty miles from Rockford and Freeport, and that did not occur until the mid-1990s. ${ }^{122}$

\footnotetext{
${ }^{117}$ Ibid, ix- x, 225-226.

${ }^{118}$ Kevin M. Kruse, White Flight: Atlanta and the Making of Modern Conservatism. (Princeton: Princeton University Press, 2005), 15.

${ }^{119}$ Roger Biles, Illinois A History of the Land and Its People. (DeKalb: Northern Illinois University, 2005), 256.

120 Ibid.

${ }^{121}$ Urban and Wagoner, 261; Biles, 271, 275.

${ }^{122}$ Cathy Finch, E.d.S., twenty-four years serving in high school administration in five school districts in Northwest Illinois, former member of the I.H.S.A. Board of Directors, and former Assistant Regional Superintendent for the Regional Office of Education for Stephenson County, interview by author, February 18, 2014.
} 
Catholics realized in the 1960s "that what we had once confidently assumed" should be the religious education of our youth "was no longer realistic," and that adapting to a mindset of social justice was "a crucial test." ${ }^{123}$ When Catholic bishops gathered nearly two hundred years earlier for the Third Plenary Council in 1884, "Catholic parents were instructed to send their children to (parochial) schools." ${ }^{124}$ While "less than half of the Catholic, school-aged population attended these schools" and "not all Catholic bishops and pastors were uniformly supportive of parish schools," there was, nonetheless, a pressure to conform." 125 "Catholic education had been established in order to make provision for the religious formation of the young."126 However, with the changes in American, post-war culture and the updating within the Catholic Church as a result of the 1962-1965 Second Vatican Council, the faith emphasis of Catholics shifted from that of religious preservation to that of personal spiritual development, social justice, and ecumenicalism.

When George N. Shuster wrote that "Man is not a gadget but a riddle -- a matter-of-fact definition anyone who begins to teach should know, and which everybody who has taught will have learned by the sweat of his brow," his recognition of the individuality of each student under one's tutelage was apt metaphor for the aggiornamento (updating) of the Catholic Church undertaken by the Second Vatican Council. ${ }^{127}$ In Freeport, “on November 29, 1964, the first Sunday of Advent, St. Mary’s parishioners witnessed the introduction of English (in lieu of Latin) into parts of the

\footnotetext{
${ }^{123}$ Shuster, 2, 3.

${ }^{124}$ Urban and Wagoner, 188.

${ }^{125}$ Walch, 4, 38.

${ }^{126}$ Shuster, 2, 3.

${ }^{127}$ Shuster, 6.
} 
Mass."128 "Fr. Regan celebrated this Mass facing the congregation," and the attendees gave verbal responses of prayers. ${ }^{129}$ Five years later, the "folk mass came to St. Mary's under the direction of assistant pastor Fr. David Beauvais." ${ }^{\prime 30}$ Priests like him respected well that "this was the most educated generation of Catholics in the history of the country," and there was no room in a successful parish for paternalism. ${ }^{131}$

Like the First Vatican Council (1869), Vatican II was also ecumenical, including "the patriarchs of the Eastern rite Catholic Church," yet it was the latter council that would invite the lay body of the church to interact in more ecumenical ways in their daily lives. ${ }^{132}$ In America, "a nation eager to define itself as God-fearing and against godless communism, religious leaders assumed a more public presence," and priests worked alongside other ministers and rabbis "on civic committees or to preside at city events.",133 “Judeo-Christian" became a popular, civic-minded phrase, and pressure to stay within one's own Catholic flock had lost its edge. ${ }^{134}$

By the 1970s, it became clear that the anticipated, explosive growth at Aquin High School, projected to reach an enrollment at nearly seven hundred by 1969, had not, and would not, materialize. Rather the numbers moved only to the three hundred mentioned above, stagnated, and then began their decline. ${ }^{135}$ Yet, despite near closure in the mid-1970s and serious financial hardship in the 1980s, Aquin remained open, and the reasons why it survived can be found in the faith and success of the diocesan hierarchy and Aquin laity, and of the latter, an invested identity.

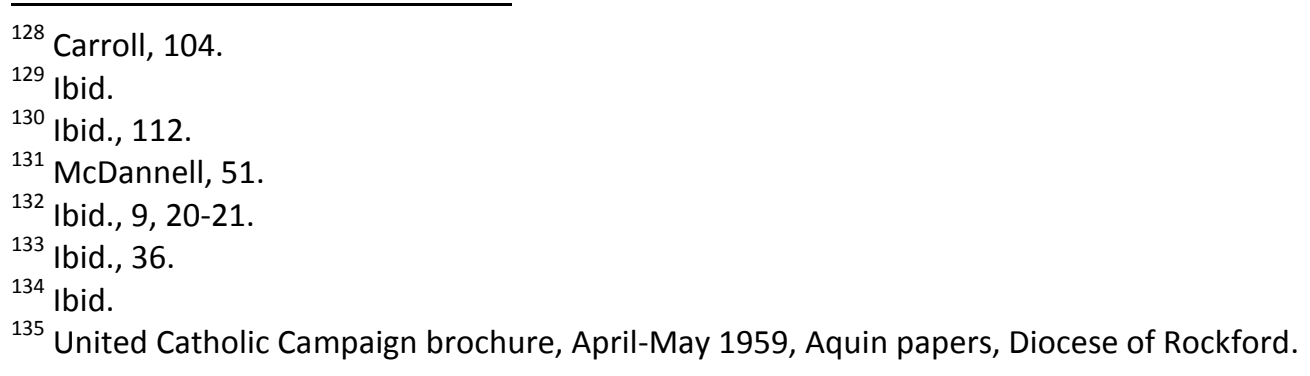




\section{CHAPTER III}

\section{SURVIVING THE 1970s AND 1980s, THE HIERARCHICAL PERSPECTIVE}

Statistically, American Catholic women married in the early 1950s bore four children compared to the average of three for non-Catholic women, and even in the early 1960s, Catholic family size was 20 percent larger than that of other families. ${ }^{136}$

However, by the mid-1960s one third of Catholics used oral contraception ("the pill") for family planning, and "Catholic fertility was on the decline" until it reached that of non-

Catholics in the 1970s. ${ }^{137}$ "Approved for contraceptive use by the FDA in 1960," the pill was more than 99 percent effective in preventing pregnancy, and it became the "single most widely used contraceptive method among married Catholic women."138 Birth rates of American Catholic families were higher in the 1950s than in previous generations due largely to a "vigorous campaign" in the 1920s by the Church against artificial birth control. ${ }^{139}$ Coincidentally, it was during that 1950s era of large Catholic families when "unions increased factory wages," education "became the ticket to affluence," and "Catholics enthusiastically embraced parochial education." ${ }^{140}$ In that golden age of

\footnotetext{
${ }^{136}$ McDannell, 191.

${ }^{137}$ Ibid., 192.

${ }^{138}$ Beth Bailey, Sex in the Heartland. (Cambridge: Harvard University Press, 1999), 105-106.

139 Ibid., 190.

140 Ibid., 47.
} 
American Catholic education there were simply more children, a greater emphasis on education, and families in better financial positions to afford parochial school for their kids. That matrix of demographic factors, however, did not survive the 1960s, and this was true, also, in Illinois. As outlined in Chapter 2, the post-war shifts in American culture, Vatican II changes in the Catholic church, and the long-term success of Catholic schools at assimilating earlier, poorer Catholics culminated in a decline in Catholic school enrollment and subsequent decrease in the financial stability of those schools.

The loss of students experienced at Aquin was felt, also, in the public system as the last of the post-war "baby boomers" made their way through America's schools. From 1946 to 1964 there was "a demographic explosion that added more than 50 million bawling babies to the nations' population" as a result of vast numbers of soldiers returning home from the Second World War (WWII) to a booming economy and, thus, with a heightened sense of confidence in their futures. ${ }^{141}$ The final cohort of "baby boom kindergarteners" entered school in 1969, and graduated high school in 1982. To some degree Freeport seemed to follow this trend, with public and Catholic school enrollment numbers increasing from the 1960-1961 school year through that of 1969-1970, and then decreasing in both schools after that point. ${ }^{142}$ The baby boom "was followed by a deepening birth dearth" across the country, and "fertility rates had dropped below the

\footnotetext{
${ }^{141}$ Dan Barry, “Boomers Hit New Self-Absorption Milestone: Age 65," New York Times (December 31, 2010), http://www.nytimes.com/2011/01/01/us/01boomers.html?pagewanted=all\& $r=0$ (accessed April 10, 2014); David M. Kennedy, Thomas A. Bailey, and Mel Piehl, The Brief American Pageant. (Lexington, Massachusetts: D.C. Heath and Company, 1996), 567.

${ }^{142}$ Freeport School District 145 Staff Directories, for years 1960-1961 through 1994-1995, Freeport School District 145, Freeport Public Schools papers; Stephenson County Superintendent of Schools Annual Directories, for years 1965-1966 through 1982-1983, Stephenson County Regional Office of Education; Sue Valkema, secretary of the Assistant Superintendent for Curriculum for C.U.S.D. 45, email, February 10, 2014; Kathy Runte, Superintendent of Aquin Catholic Schools, email interview by the author, January 29, 2014.
} 
point necessary to maintain (1960s) population figures." 143 This decline "left in its wake closed schools and unemployed teachers" across America. ${ }^{144}$ The Freeport Catholic Schools (FCS) lost 48.4 percent of their enrollment by 1973-1974. ${ }^{145}$ The drop in numbers in the Catholic schools, however, was not due exclusively to fewer children in Freeport. While FCS had been educating 18.4 percent of Freeport students in the 19651966 school year, they taught just 8.3 percent of them a decade later in $1975-1976 .{ }^{146}$ Nationally, in the thirty-six years between 1960 and 1996, there had been a fifty percent decrease in Catholic elementary and secondary schools with a total loss of 2.4 million students, 80,000 Sisters, and an annual average loss of seventy-five schools. ${ }^{147}$ “Many diocese recorded enormous one-year drops in 1968 and 1969," and Time reported that "As public school taxes and parochial school tuition go up, many" families "cannot afford both."148 Francis Phelan of the Education Voucher Project concluded that "there were many causes for the decline of Catholic schooling, so many in fact, that they were difficult to delineate without adding to the confusion."149 The number of available students was lower, expenses had gone up, and there was a complicated myriad of cultural and religious changes that had transpired due to Vatican II and the social movements of the 1960s.

Additionally, "the bursting of the postwar (economic) boom" gave birth to 1970s "stagflation" - according to historian Bruce Shulman, a "crippling coupling of high rates

\footnotetext{
${ }^{143}$ Kennedy, Bailey, and Piehl, 567.

144 Ibid., 567.

${ }^{145}$ Enrollment Documents, Aquin papers.

146 Ibid.

${ }^{147}$ McDowell, 49.

148 Walch, 180.

149 Ibid., 183.
} 
of inflation and economic stagnation." 150 Both the cost of living and unemployment rates were high, and these factors took a toll on American families; this was the greatest financial turmoil in America since the Great Depression. ${ }^{151}$ In fact, Shullman described the unemployment rates of the late 1970s as "tenacious" and inflation as an "out-ofcontrol rage." 152 The increase in the cost of living "leaped up at double-digit rates."153 Mike Cieslak (Research and Planning for the Rockford Diocese 1984-present) reflected that inflation had been incredible and that one needed to remember this fact when considering the way in which Catholic schools struggled in the 1970s. ${ }^{154}$ David M. Kennedy, Thomas A. Bailey, and Mel Piehl explained that the young adults of the baby boom generation "faced the depressing prospect of a living standard that would be lower than that of their parents." 155 They elaborated that the dual initiatives of President Lyndon Johnson's Great Society social programs and the war in Vietnam were the root causes of the subsequently stagnant economy and growing inflation, and this was exacerbated by the spike in the price of Middle East oil. ${ }^{156}$ Oil-rich Arab nations had enacted an oil embargo against the United States in response to U.S. support of Israel, and in 1974 when the embargo was finally lifted, "the Middle Eastern sheiks had approximately quadrupled their price for crude." 157 Overall, in the United States "the

\footnotetext{
${ }^{150}$ Bruce J. Shulman, The Seventies: The Great Shift in American Culture, Society, and Politics. (Cambridge: Da Capo Press, 2001), 7-8.

${ }^{151}$ Ibid., 8.

${ }^{152}$ Ibid., 129-131.

${ }^{153}$ Ibid.

${ }^{154}$ Cieslak.

${ }^{155}$ Kennedy, Bailey, and Piehl, 615.

${ }^{156}$ Ibid.

${ }^{157}$ Ibid., 622.
} 
cost of living more than tripled in the dozen years following Richard Nixon's inauguration;" it was "the longest and steepest inflationary cycle in American history." 158

President Jimmy Carter (1977-1980) attempted nimbly to steady the economy by alternating "stimulus and contraction" plans according to conditions, but he was perceived by the public as a "waffler." ${ }^{159}$ Gasoline rationing and rising property taxes were signs of the times, and all of the associated hardships had taught Americans to "rely on themselves more than on the government." ${ }^{160}$ In April of 1979, Carter lead "extraordinary deliberations" at Camp David with "over 100 leaders from all walks of life," over a ten day period of retreat and intense discernment. ${ }^{161}$ He emerged to accept presidential blame for the nation's troubles, but also to admonish Americans for "selfindulgence" and "parochialism." 162 He tried to invoke a national confidence and willingness to identify as a proud America, knowing that psychological factors swayed heavily economic decisions, and thus, the economy of the country.

This sentiment was made clear more recently, at the London Business School's 2013 Global Leadership Summit when Iceland President Olafur Grimsson explained his country's relatively quick recovery from the early twenty-first century global recession, "Many people tend to forget that an economy is not just a set of associations between financial institutions and companies, and so on. An economy is fundamentally a community of people, and unless the people feel confident and have a vision and a will to move forward, it doesn't matter what kinds of policies you try to implement. You will

\footnotetext{
${ }^{158}$ Kennedy, Bailey, and Piehl, 615.

159 Shulman, 130.

160 Ibid., 140-142.

${ }^{161}$ Kennedy, Bailey, and Piehl, 628.

${ }^{162}$ Shulman, 141.
} 
never be able to succeed." ${ }^{163}$ Yet, in 1970s America, an increasingly independent spirit had developed, and it did so alongside a growing weariness. The United States was not confident in its economy or its president, and Ronald Reagan was elected to replace Carter in $1980 .^{164}$

The basement of St. Thomas Elementary School in Freeport served as a polling place, and members of the neighborhood arrived to cast their ballots; one first-grader remarked to her classmate, "My parents are voting for Reagan."165 The classmate did not understand the politics of the day, but she knew this friend's comment was about "the other guy," and not her own parents' choice of candidate; it left her feeling uneasy. Carter's "exceptionally high" popularity and the allure of his "down-home" sincerity were overshadowed by the perception that he was "inept" at affecting economic leadership within Washington. ${ }^{166}$ Ronald Reagan, by contrast, offered a "sunny vision that proved popular with voters."167 His campaign got quite a boost from the "new right," a complicated movement made of various groups responding to the social changes of the 1960s and 1970s. ${ }^{168}$ His leadership, as we shall see later in this chapter, did little to lighten the path for middle and lower class Americans. ${ }^{169}$

Carter's earlier presidential warning against parochialism, ironically, came after a decline in enrollment and finances for the formerly "parochial" Catholic schools in

\footnotetext{
${ }^{163}$ President Olafur Grimsson, 2013 Global Leadership Summit, London Business School. http://Igls.london.edu, May 23, 2013 (accessed April 21, 2014).

${ }^{164}$ Shulman, 142-143.

${ }^{165}$ Scene and comment observed by the author in 1980.

${ }^{166}$ Kennedy, Bailey, and Piehl, 626-627, 631.

${ }^{167}$ William E. Pemberton, Exit with Honor: The Life and Presidency of Ronald Reagan. (Armonk, New York: M.E. Sharpe, 1998), xiv.

168 Kennedy, Bailey, and Piehl, 631.

169 Ibid., 634.
} 
Freeport. ${ }^{170}$ Not all of the challenges facing Catholic schools were directly dependent on birth rates and the national economy. Updating science curriculum, instruction, and facilities to keep pace with the better-funded public schools was costly, and the Catholic schools also faced the additional challenge of a decrease in religious vocations. The number of women religious ("nuns") dropped twenty-eight percent in the decade following the Second Vatican Council (1966 to 1976). ${ }^{171}$ Additionally, of the sisterteachers who remained, many of them were granted more latitude in choosing their modes of service, which gave to them options besides teaching and nursing. ${ }^{172}$ Those who continued to teach expected at least slight increases in their subsistence wages as well as reasonable, smaller class sizes. ${ }^{173}$ Women religious were no longer the "living endowment" the leaders of the American church once expected them to be. ${ }^{174}$ As a result, Catholic schools were hiring greater numbers of lay teachers and had to "pay them a living wage."175 In 1976 there remained at Aquin only two Sinsinawa Dominican sisters and one priest, and by 1985, Aquin and St. Thomas, St. Joseph, and St. Mary elementary schools had lost the last of their sister-teachers. ${ }^{176}$

The History of St. Mary's Catholic Church indicated that in 1968, to “insure the survival of the Catholic schools in Freeport," the parishes decided to transition from distinct parochial schools to a Freeport Catholic Schools system in which there would be grades first through fifth both at St. Mary's and St. Thomas and grades sixth through

\footnotetext{
${ }^{170}$ Carroll, 111.

${ }^{171}$ McDannell, 169.

172 Ibid., 146.

173 Ibid; Walch, 134.

174 Walch, 134.

175 Ibid., 242.

${ }^{176}$ Reverend Robert R. Miller, That All May Be One: A History of the Rockford Diocese, 1976. The Diocese of Rockford Papers; Aquin High School enrollment data forms, Aquin papers.
} 
eighth at a middle school in the St. Joseph's building. ${ }^{177}$ However, a year and a half later, in September of 1971, it had been noted that "partially defaulted parish assessments, increased costs, and the school's inability to collect tuition in substantial amounts over a period of several years" caused financial strain in the system. ${ }^{178}$ The school board raised tuition, launched "a professional fund-raising campaign," and proposed "a drive for increased enrollment." ${ }^{179}$ Despite these efforts and balanced budgets in the sampled school years of 1960-1961 and 1968-1969, Aquin began a trend of annual net losses at the start of the 1970s. ${ }^{180}$ After increasing tuition $\$ 25$ per student, Aquin had in the 19711972 year appeared to have shrunk the annual net loss to $\$ 5,872$, as compared to the roughly $\$ 15,000$ net loss the year prior. ${ }^{181}$ The 1974 North Central Accreditation report for Aquin mentioned that the school board had discussed "closing the school for (the) next year" due to low enrollment, but had then decided that Aquin "furnished a worthy alternative for their students and should continue to exist." ${ }^{, 182}$ A year later, St. Mary’s school was closed after 103 years of service. ${ }^{183}$ Another two years later, an internal reorganization brought the seventh and eighth grades into the high school building, and that facility became Aquin Junior-Senior High School. St. Joseph's became, once again, an elementary school, and St. Thomas continued as the other elementary building. ${ }^{184}$

Perhaps it was simply the bottom line of household budgets, or maybe it was a possible shift to personal autonomy in lieu of the appeal of community, but Aquin's enrollment continued to decline into the 1980s. From the mid-seventies through the turn

\footnotetext{
${ }^{177}$ Carroll, 111.

${ }^{178}$ Ibid., 115.

${ }^{179}$ Ibid., 116.

${ }^{180}$ Aquin Central Catholic High School Budget, 1960-61, 1969-70, 1970-71 and 1971-72, Aquin papers.

${ }^{181}$ Ibid.

${ }^{182}$ North Central Accreditation Report, 1974, Aquin papers.

${ }^{183}$ Carroll, 117.

${ }^{184}$ Enrollment documents, 1977-1978, Aquin papers.
} 
of the twenty-first century, the Freeport Catholic schools enrolled between 8.3 percent to 10.7 percent of Freeport students. ${ }^{185}$ Despite the appearance of attaining a loose equilibrium within this range of lower percentages, the total number of students in the town of Freeport had also dropped. ${ }^{186}$ Aquin was keeping a somewhat level percentage, but of fewer total students. Freeport's population went from an all-time high of 27,736 in 1970 down to 25,840 in 1990 , and the culprit was the loss of professional, white-collar jobs when switch and sensor manufacturer, Micro Switch, began "bleeding jobs overseas" in the "early 1980s.", 187

The United States entered a new, "international economy” in the late 1970s, when the United States, "driven by the necessity to pay for huge foreign oil bills," became increasingly dependent on "foreign trade."188 Tokyo and Hong Kong joined London and New York as powerful cities in the world market and this was concurrent with the rise of the micro-computers that propelled many nations into the "information age." "189 Whitecollar service jobs had become the core of many economies, including that of the United States, and these jobs replaced the former domination by industrial, blue-collar employment. ${ }^{190}$ Those working in jobs such as "information processing, medical care, communications, teaching, merchandising, and finance" began to outnumber manual laborers as early as 1956, and by the 1990s, service providers counted for roughly "80 percent of the workforce." ${ }^{\prime 191}$ Factory jobs, the main-stay of many towns and cities

\footnotetext{
${ }^{185}$ Enrollment documents, 1977-1978, Aquin papers.

186 Ibid.

${ }^{187}$ Census Quick Facts; Dr. Edward Finch, email, February 22, 2014. According to http://www.hrcaz.org (accessed April 8, 2014), the Micro Switch was invented in Freeport by Peter McGall in 1932, and production has been owned by Honeywell since 1950.

${ }^{188}$ Kennedy, Bailey, and Piehl, 655.

189 Ibid.

190 Kennedy, Bailey, and Piehl, 655.

191 Ibid., 654.
} 
across the United States, were moving overseas, and the change in the types of jobs available caused great hardship for many middle class folks.

President Reagan's “supply-side economics" ("Reaganomics") cut taxes and exercised "budgetary discipline" in anticipation of increased productivity and investments and economic growth. ${ }^{192}$ The economy seemed to recover from the initial recession - the most severe "since the 1930s" - however, "for the first time in the twentieth century, income gaps widened between the richest and the poorest Americans." 193 A school document entitled "Enrollment Concerns" cited a system-wide loss of 83 students from the Freeport Catholic Schools after the 1985-1986 academic year. ${ }^{194}$ There was an additional loss of forty-six students in the 1987-1988 year. ${ }^{195}$ In "informal discussions with parents" leaving the system, "they indicated high tuition" was "part of the reason they were leaving."196 This was also a time when the two remaining elementary schools went to "attendance centers" with all Catholic school children in Freeport attending St. Joseph Elementary for grades kindergarten through fourth and attending St. Thomas for grades fifth and sixth. ${ }^{197}$ The school board expressed concern that this new arrangement disrupted what had previously been a continual six or sevenyear attendance within one elementary school, and that this introduced an additional transition point (entering $5^{\text {th }}$ grade) at which it was easier for families to make the switch to the public schools. ${ }^{198}$ Aquin alum, parent, and former school board member Kay Hadjokas suggested that kids began to "expect more freedoms," and parents felt more

\footnotetext{
192 Ibid., 633.

193 Ibid., 634.

${ }^{194}$ Enrollment Concerns, Aquin papers.

195 Ibid.

196 Ibid.

${ }^{197}$ Enrollment concerns, Aquin papers.

198 Ibid.
} 
obliged to honor their children's choices, including their preferences for schooling. ${ }^{199}$ It was also noted in the "Enrollment Concerns" document that Aquin had graduated a very large high school class of fifty-six students, which was "replaced" the following fall with a kindergarten class of only thirty kids. ${ }^{200}$ In a small school, year-to-year fluctuations are felt more profoundly.

Working to identify the causes of retention issues, the school also did what it could to stop the financial bleeding with the establishment of a foundation, "Education Through the '80s," that raised $\$ 500,000 .{ }^{201}$ It was, however, a depleting fund development, and it was spent on infrastructure needs. ${ }^{202}$ Financially, Aquin's greatest woes hit in the 1980s, as the budget reports showed significant deficits. ${ }^{203}$ By the end of the 1983-84 school year, the Freeport Catholic Schools added a net annual loss of $\$ 83,700$ to an accumulating deficit for an approximate debt of $\$ 329,000 .{ }^{204}$ Small enrollment numbers left a fiscal burden of constant overhead expenses to be covered by the tuition from fewer students. According to Father Beauvais who formerly served at Saint Mary's Parish and Kay Hadjokas, those families who continued to send their children to Aquin were not necessarily any wealthier than the families who left to enroll their children in the public school system. All interviewees who were asked about the socio-economic demographics of Aquin concurred readily that the school had always been a humble, blue-collar sort of place. In fact, alum, parent, and long-time board member Tim Smith offered, “The 'country club kids' all went to Freeport (High

\footnotetext{
${ }^{199}$ Kay Hadjokas, interview by author, January 18, 2014.

${ }^{200}$ Ibid.

${ }^{201}$ Cieslak.

202 lbid.

${ }^{203}$ Freeport Catholic Schools Financial Statements, 1984-1985, 1985-1986, 1986-1987, 1989-1990, and 1990-1991, Aquin Papers.

${ }^{204}$ Ibid.
} 
School)."205 Rummage sales and BINGO concessions swelled with parent volunteers, and the threat of a school closure often seemed imminent. Alum, parent, and current teacher Bill Pospischil recalled a day in his senior year (1974-1975) when news came through the Aquin "grapevine" that "someone from Bishop O'Neill's office was on their way over to close Aquin but that the Bishop called and stopped it."206

Mike Cieslak suggested that a "paucity of good fiscal management" can certainly exacerbate a deficit. $^{207}$ Cathy Finch, teacher and principal at St. Thomas (1977-1985) followed by a one-year tenure as Aquin principal before taking a position at Freeport Public High School, indicated that, indeed, the FCS Board created the new position of Financial Manager in the 1980 s to firm up accounting practices and reduce the deficit. ${ }^{208}$ Alum, parent, and current superintendent of Aquin Catholic Schools Kathy Runte admitted that "we definitely have a hole in our financial history," as records for the years 1973 through 1981 are to be found nowhere in the school files nor archives. ${ }^{209}$ This seemed a clear case in point of the afore-mentioned fiscal disarray. Runte offered as anecdote that "students from that time remember attending school only four days per week (in the winter) because (the) school couldn't afford heating oil - kids wore coats to class. $" 210$

A total of $\$ 450,000$ was raised by way of "Education Through the '90s," and, similar to the previous foundation, the schools used the principle to balance the yearly budgets and to cover dire, basic infrastructure needs. ${ }^{211}$ With the fiscal processes and

\footnotetext{
205 Tim Smith, interview by author, January 18, 2014.

${ }^{206}$ Bill Pospischil, interview by author, February 19, 2014.

${ }^{207}$ Cieslak.

${ }^{208}$ Cathy Finch.

${ }^{209}$ Runte.

210 Ibid.

211 Ibid.
} 
accountability cleaned up, FCS stopped financial hemorrhaging; yet, the size of the longterm deficit had been large. It was not until 1991 that the old deficit was erased thanks to the Parish-Sharing Program of the Rockford Diocese that granted them $\$ 234,709$ as part of the plan "to help clear up 4.1 million dollars" of debt "collectively for all diocesan entities."

What was the role of the church hierarchy as these winds of change blew through the Catholic schools? McCluskey advocated in 1968 a systematic diocesan approach for America to address problems in what was then parish-based schooling. ${ }^{213}$ He suggested it would be "fairer and more practical" for the schools of the "rich suburban parish" and the "declining downtown parish to be paid out of the same central fund." ${ }^{214} \mathrm{He}$ highlighted the perceived difficulty otherwise in "effect(ing) improvement on a large scale because each parish" guarded "the autonomy of its parish school."215 While the Freeport Catholic Schools, indeed, became a Freeport-wide Catholic school system, it was locally run with only diocesan oversight. After the 1960s, diocesan offices in America were often "a major source for leadership training," and services such as curriculum assistance and "legal and financial advice." 216 However, they were also often decisive on final matters of Catholic school closings and consolidations.

The conventional wisdom of thoughtful Aquinites led them to surmise that Aquin High School was kept open due to the relatively blue collar work ethic and humility they shared with Bishop Arthur J. O’Neill of their Rockford Diocese (1968 until 1994). ${ }^{217}$

\footnotetext{
${ }^{212}$ Father David Beauvais, interview by author, February 19, 2014.

213 McCluskey, 264-265.

214 Ibid.

215 McCluskey, 266.

${ }^{216}$ Bryk, Lee, and Holland, 158.

${ }^{217}$ Reverend Robert R. Miller; “The Most Reverend Arthur J. O'Neill," Diocese of Rockford. http://www.rockforddiocese.org/Bishop-ONeill (accessed March 24, 2014). Bishop O'Neill was the
} 
Undoubtedly, O'Neill's thirteen years as pastor for St. Thomas Aquinas Church in Freeport gave ample opportunity for him to have created personal connections with Freeport families and the Aquin community. ${ }^{218} \mathrm{He}$ spent only two years at St. James ProCathedral before his tenure in Freeport, and then, just one and a half years afterward with St. Peter Church in Rockford before becoming bishop. ${ }^{219}$ During his pastorship in Freeport, he was an ardent supporter of the 1959 "Building Campaign" to construct an addition to Aquin and a new St. Thomas Church. ${ }^{220}$ The statistics communicated in the fundraising brochure made the assumption that all babies baptized in the Catholic parishes of Freeport would attend Aquin, and that enrollment there could reach as high as 1,000 students. ${ }^{221}$ The Catholic leaders of Freeport promoted this campaign as "a test of faith for every Catholic," and O'Neill's individual contribution to the brochure waxed passionately, “ . . . Catholics in all of the parishes of Greater Freeport are 'joining hands' in what will be one of the largest and most significant efforts in our local Church history. Each of us will contribute to the writing of this chapter. How well it reads will be determined by what each of us accepts as our responsibility." ${ }^{222}$ Apparently, adequate sacrifice was made by Catholic Freeporters. Father O’Neill, alongside Aquin

\footnotetext{
longest serving bishop of the diocese; originally from nearby East Dubuque and described as the "first native of the Rockford Diocese to serve as bishop." He died only recently, in 2013, at the age of ninetyfive.

${ }^{218}$ Reverend Robert R. Miller, 92.

219 Ibid.

220 United Catholic Campaign, Building Campaign brochure, 1959, Aquin papers, Diocese of Rockford.

${ }^{221}$ United Catholic Campaign, Building Campaign brochure, 1959, Aquin papers, Diocese of Rockford.

222 Ibid. On a subsequent page in the brochure, O'Neill's words provoked Freeport parishioners with "How will it read to those who follow?" This struck the author of this thesis as poignant, as the brochure itself is being read and determinations attempted as to what the campaign meant historically.
} 
Superintendent Monsignor Charles F. Conley, broke ground on the site of the high school addition on August 30, 1959. ${ }^{223}$

Bishop O'Neill was a man one might have called "salt of the earth," as he was humble and committed to service. Two years after taking lead of the Rockford Diocese, Bishop O’Neill made the final determination that St. Peter Church of Rockford would be the diocesan Cathedral, and that the newest addition to the diocese should be built according to modest plans - a deliberate departure from the original multi-million dollar bid for a new cathedral. ${ }^{224}$ Bishop O’Neill committed the new structure as Holy Family Parish. $^{225}$ Bishop Lane, who had commissioned the cathedral plans had been the first to halt the expensive project, and after his passing, Bishop O’Neill quickly concurred and conclusively put an end to the over-priced plan. A particularly telling anecdote about O’Neill was that when his elderly mother was living with his sister at her convent, he was found on one of his visits with her, painting the furniture out on the back patio. ${ }^{226}$ When the sisters discovered his labors and insisted the bishop need not do such dirty and tiring work, he insisted that he would continue the task, as he owed them for the care they gave to his mother. ${ }^{227}$ Additionally, while designated a Monsignor by his predecessor, Bishop Lane, O’Neill joked that he was only made Monsignor so that Monsignor Ray Wahl would have someone with whom to walk during processions. ${ }^{228}$ In the spirit of Vatican

\footnotetext{
${ }^{223}$ Reverend Robert R. Miller, That all May Be One, 94. Monsignor Conley was also the pastor of St. Mary's Church in Freeport, and the priest for whom the current Aquin High School football field is named - "Conley Field."

${ }^{224}$ Beauvais; Cieslak; Laurine M. Easton, William F. Easton, and Msgr. David Kagan, The Diocese of Rockford 1980-2008, (Diocese of Rockford: 2007).

225 Ibid.

${ }^{226}$ Sister Joella Miller, O.P., telephone interview by author, March 17, 2014.

227 Ibid.

${ }^{228}$ Beauvais; Cieslak; Dr. Edward Finch. Ray Wahl was of the "Wahl Family," famously wealthy due to their successful business in hair-cutting tools.
} 
II, Bishop O'Neill “decided not to make any Monsignors," and had said that he felt "creating Monsignors would cause division among the priests."229

He also wanted to mend divisions between priests, women religious, and laity. Sister Joella Miller, former Superintendent of Schools for the Rockford Diocese, expounded in a recent interview on her great respect for Bishop O'Neill as a consequence of his respect for women in the church. ${ }^{230}$ "He was a great listener and gave wise advice." ${ }^{231}$ Miller, of the Adrian Dominican Sisters, lead the Rockford Diocese on educational matters from 1981 until 1993, and she remembered well the Bishop's affection for the people of Aquin and the sense of family he felt at the school; he said to her on numerous occasions, "We can't let that school close."232 During the tenure of Miller's predecessor, O'Neill had established a Catholic school structure entirely unique relative to all surrounding diocese in the Midwest, whereby the parishes funded the schools and there were local boards of education. ${ }^{233}$ That was a system of local financing and control, and "it was the saving grace of the schools.",234

Indeed, very few schools closed in the Rockford Diocese, according to Father Beauvais who, after serving St. Mary's parish, completed graduate school in social work and then served in leadership roles within the diocese, one of which was Vicar of Finance (1987-1990). ${ }^{235}$ Most other diocese funded the schools from a central account, much as was suggested by McCluskey, and while this afforded the benefits argued by McCluskey,

\footnotetext{
${ }^{229}$ Beauvais; Cieslak. By contrast, O'Neill's successor, Bishop Tom Doran, made nearly twenty-five Monsignors. Pope Francis dictated in 2014 that priests under the age of sixty-five should not be made Monsignors so as to reduce career ambitions and better focus the church on service.

${ }^{230}$ Sister Joella Miller.

${ }^{231}$ Ibid.

${ }^{232}$ Sister Joella Miller.

${ }^{233}$ Sister Joella Miller.

${ }^{234}$ Ibid.

${ }^{235}$ Beauvais.
} 
it also put schools at the mercy of the diocesan officials, because in that set-up, the funds were controlled entirely by the hierarchy. In the Rockford Diocese, the Bishop had important influence; however, the families of any particular community could rally financial support for their particular school and, hence, preserve some degree of local fiscal autonomy. As a result, the Rockford Diocese did not see the national trend of a 50 percent drop in the number of Catholic schools in the years between 1960 and 1996 as noted earlier in this chapter.

Fewer available students, increasing expenses, cultural change, and the Vatican II modernization of the Church all impacted Catholic schools. These national trends in Catholic Education in the 1970s and 1980s clearly influenced Aquin Catholic High School as much as did the minor, local tremors of change. Tim Smith recounted times of turmoil that arose in the 1980 s as well as later, in the 1990 s. $^{236}$ He recalled worry about folks trying to close Aquin, time spans when administrators at the high school did not provide solid leadership, and moments when it seemed that selfish attitudes prevailed. Aquin had clearly faced its share of metaphorical peaks and valleys.

From the diocesan, economic perspective Beauvais suggested that due to Freeport's smaller size and the economics of the town, Aquin had to "pool resources earlier" than most communities, and that "independent spirit" served them well. ${ }^{237}$ Beauvais offered also a pragmatic reality of the numbers - that it's difficult to run efficiently a school of fewer than 250 students, and he conceded that "Bishop O'Neill ruled more with his heart than his head." ${ }^{238}$ One could argue that Beauvais was also ruled by his heart, as his concern rested with the overall picture of a faith community, "If

\footnotetext{
${ }^{236}$ Smith.

${ }^{237}$ Smith.

238 Ibid.
} 
a parish was spending more than 30 percent of its funds on a school, it would be difficult to serve parishioners' other needs and to serve the poor."239 Mike Cieslak of the Office of Research and Planning for the Rockford Diocese (1984-present) admitted that O'Neill equivocated frequently, and that the Bishop's strategy for delaying difficult decisions was to lose himself in inconsequential minutia, such as the time he spent over an hour reconstructing one of Mike's letters at time most inopportune. ${ }^{240}$ Cieslak added that in addition to O'Neill's aversion to closing any diocesan institutions, it was the labor of Father Beauvais on the Parish Sharing Program that ultimately provided Aquin with that significant financial boost in 1991 it needed to regain solid financial ground. ${ }^{241}$ Because of this, Aquin was able to continue offering a small-school, Catholic option for Freeport families.

\footnotetext{
${ }^{239}$ Ibid.

${ }^{240}$ Cieslak.

${ }^{241}$ Ibid.
} 


\section{CHAPTER IV}

\section{SURVIVING THE1970s AND 1980s, THE VIEW FROM THE SUBALTERN,}

\section{PART I}

In Thomas C. Hunt and Timothy Walch's collection of essays about urban Catholic schools, they found community leaders often "respected what the Catholic schools achieved," and also "found them to be assets in constructing a stable civic culture." 242 Education scholar, Father Harold Buetow, argued in 1985 that "government schools need the nongovernment sector to challenge them," and that the reverse was also true. ${ }^{243}$ "Both remain," he concluded, "necessary for the good of the country." 244 More recently, Mike Cieslak of the Rockford Diocese referred to Aquin as “one of Freeport's jewels," and that it was an important component of the community, "a thread in the fabric that if tugged, all of Freeport would feel it." ${ }^{245}$ Dr. Ed Finch, retired from teaching at Freeport High School and from directing the Stephenson County Historical Society, was also a school board member at Aquin and parent of two Aquin alums. He suggested that Aquin was "not considered a competitor" of Freeport High School, "neither of students nor athletes," and it seemed there was always a "grudging respect for Aquin's athletic

\footnotetext{
${ }^{242}$ Hunt and Walch, xi.

243 Buetow, 67.

244 Ibid.

${ }^{245}$ Cieslak.
} 
success."246 It was unlike the animosity Finch believed was sometimes felt between public and private schools in other towns. ${ }^{247}$ He remembered working on the "Education Through the "80s" fundraising campaign for FCS when a number of public-school parents from St. Thomas Parish pledged funds to the cause.

Finch also recalled, however, a particular coworker at the public high school who seemed to have some sort of personal "ax to grind" where Catholic schools were concerned. Finch's wife, Cathy, having worked in both the Catholic and public schools in Freeport, recalled once clarifying to a Freeport resident that the perception of Aquin folks as being arrogant was a misunderstanding of the Aquinites' pride in what Aquin was able to achieve with such limited resources. ${ }^{248}$ It was a somewhat hardscrabble place, and the people's greatest satisfaction came from the humblest of achievements. "Aquin could do so much with so little - it was education by desire."249 People outside of Aquin probably thought it quaint and maybe even "funny because of the small size, stricter dress code, and notion that it was a safe environment."250

Sixth-generation Freeporter, George Buss, graduated from Freeport High School in 1975 and returned after college to teach in his hometown for sixteen years and then became a director for the equity initiatives program for schools called Advancement Via Individual Determinaton (AVID). ${ }^{251}$ Buss indicated, first, that matters of race were inconsequential in families' decisions about Freeport high schools. ${ }^{252}$ The percentage of minority (primarily black) students at FHS held at a relatively steady 20-23\% throughout

\footnotetext{
${ }^{246}$ Dr. Edward Finch, interview by author, January 31, 2013.

${ }^{247}$ Dr. Edward Finch.

${ }^{248}$ Cathy Finch.

249 Ibid.

250 Ibid.

${ }^{251}$ George Buss, interview by author, May 23, 2014.

252 Ibid.
} 
the 1970s and 1980s, and those African-American families were mostly "traditional Freeport families" from the late 1800s and early 1900s who arrived there because it was the last northern stop of the Illinois Central Railroad. ${ }^{253}$ Buss then agreed with Ed Finch that Aquin was not a direct competitor with Freeport High School. Anecdotally, he shared that when he was attending FHS in the mid-70s, Aquin was perceived as a religious school more than it was known for academic rigor and that after some students accomplished the Catholic sacrament of Confirmation and the associated, required religious training, approximately fifteen of them transferred to FHS. ${ }^{254}$

At the administrative level, the sense of relative cooperation seemed to ring true, as well. During the 1986 football playoff series, Aquin's Conley field was inundated with snow, and FHS readily agreed to allow Aquin to host the game on their field. ${ }^{255}$ The FHS message board out in front of their large school rooted on the cross-town Catholic school as the Bulldogs later headed south to play the Macon Ironmen for the 1986 state championship - "The Bulldogs are Macon Their Way Downstate."256 Cieslak at the Diocesan office suggested the positive press about Aquin's football program contributed to successful impressions of the City of Freeport. ${ }^{257}$ In addition to the football connection, FHS welcomed the annual Northwest Illinois Conference (NWIC) track meet, officially hosted by Aquin, at Freeport High's all-weather track. ${ }^{258}$

Aquin alum, teacher, and coach, Bill Pospischil suggested that if there was no Aquin that Freeport families would lose "choice." 259 There would be just one option for

\footnotetext{
253 Buss.

254 Ibid.

255 Pospischil.

${ }^{256}$ Recollection of the author.

257 Cieslak.

${ }^{258}$ Author's experiences.

${ }^{259}$ Pospischil.
} 
high school, it would not have a Catholic flavor, and it would be a big-school environment. For some students, FHS was a great fit, but for others not so much the right size. Enrollment at FHS in the 1970s and 1980s ranged from approximately 1500-1600 students, whereas Aquin began the 1970s with roughly 300 students and shrank by 1990 to an enrollment of around 100 kids. Ed Finch concurred with Pospischil, as he recalled a new student in his English class at FHS who continued to seem adrift, but later found the right place for herself when she enrolled at Aquin. The girl's parents reported how welcomed they felt when they visited AHS. When interviewed, Finch stated that Aquin "is special in what it's trying to do - provide Catholic education, and how it tries to go about doing it - balancing the academic demands of the modern world with the spirituality. ${ }^{, 260}$ Alum, parent, grandparent, and long-time school board member Tim Smith attributed the success of Aquin students to the high degree of structure at the school. ${ }^{261}$ The 1974 North Central Accreditation (NCA) report on Aquin offered that activities were "well-attended" and the "physical activities program" was "phenomenal;" the explanation offered was that "perhaps a closer bond is developing as students interact purposefully" and "with pride in their Aquin identity."262

By contrast, in R. Scott Appleby and Kathleen Sprows Cummings' Catholics in the American Century: Recasting Narratives of U.S. History, Wilfred M. McClay's essay highlighted the irony at the center of his own claim - that "Catholics' social 'success' had come at the expense of the Catholic identity." 263 Therefore, some argue that Catholics of the late twentieth century sacrificed the intensity of their distinctive, sacrificial devotions,

\footnotetext{
${ }^{260}$ Dr. Edward Finch.

${ }^{261}$ Smith.

262 NCA report, 1974, Aquin Papers.

${ }^{263}$ R. Scott Appleby and Kathleen Sprows Cummings, Catholics in the American Century: Recasting Narratives of U.S. History. (Ithaca: Cornell University Press, 2012), 139.
} 
prayers, and customs for the sake of assimilation into American culture and concurrent economic success. As will be outlined later, however, others claim that Catholics have maintained their unique outlook and practices.

Political science scholar Virgil C. Blum claimed in 1969 that "on the basis of every national test available, children who go to Catholic schools get as good an education as children who go to public schools."264 "The highly structured academic programs of Catholic high schools not only produce relatively high levels of academic achievement equitably distributed" across social classes, but were also effective at student retention. ${ }^{265}$ The "student body was well-grounded in mathematical and literary skills," and "there was little evidence" that many choices in course options "were as valuable" as mastery of those "skills so necessary for future success."266 Scholars Bryk, Lee, and Holland added that the smaller size of Catholic schools "is a significant feature of their organization."267 These benefits, however, came with a tuition price tag, and as detailed in Chapter 3, the 1970s "stagflation" made private education unaffordable for some families.

Whereas Aquin graduates reported plans to attend college at rates of 71 percent in the 1978 graduating class and 62 percent for the 1979 class, those percentages rose to a range of 80 to 89 percent for classes graduating in 1980 through $1986 .^{268}$ This compares to 1978 -1986 national trends ranging from 49.3 to 57.7 percent and patterns at Freeport

\footnotetext{
${ }^{264}$ Virgil C. Blum. Catholic Education: Survival or Demise? (Chicago: Argus Communications Co., 1969$), 97$.

265 Bryk, Lee, and Holland, 274.

${ }^{266}$ Walch, 245.

${ }^{267}$ Bryk, Lee, and Holland, 78.

${ }^{268}$ Aquin High School Enrollment Data Forms, Aquin papers.
} 
High School of 36 to 58 percent. $^{269}$ The rate of college attendance by Aquin students was significantly higher than local and national norms. In 2014, the national rate of college attendance by graduates of Catholic high schools is $84.9 \%$; decades earlier, the AHS rates were within that range. ${ }^{270}$ Alum, former parent, and current superintendent Kathy Runte added that despite coming from the smallest school in the Rockford Diocese and of the area at large, Aquin students performed well in college. Aquin had emphasized the college preparatory plan for its students. The 1974 NCA committee on Aquin reported that "course offerings were very limited for non-college students" and that there was a "lack of specific vocational guidance." 271 Additionally, eight years later, the 1982 NCA committee on Aquin reported the "apparent success of the great majority of graduates in entering and completing post-secondary education." ${ }^{272}$ Another six years later, the 19881989 NCA committee on Aquin reported a "low drop-out rate," and "above average test scores," but that "by its nature excludes individuals with learning disabilities or technical school interest." 273 However, another entry found later in the same report indicated the availability of dual enrollment for children with disabilities, and students needing a vocational path had benefitted from participation in the Stephenson Area Career Center (S.A.C.C.) program at Freeport's Highland Community College. ${ }^{274}$ S.A.C.C. began in 1975 to provide training in twelve occupational areas including health services, auto-

\footnotetext{
269 "Digest of Education Statistics," National Center for Education Statistics, U.S. Department of Education, http://nces.edu.gov.1999 (accessed March 26, 2014); Freeport Public Schools papers, Freeport Public Schools Unit Office.

${ }^{270}$ National Catholic Education Association, http://ncea.org/about-us/catholic-education-information (accessed May 18, 2014).

${ }^{271}$ NCA report, 1974, 27.

272 Ibid., 1982, 13.

273 Ibid., 1988-1989, 7-8.

${ }^{274}$ NCA report, 1988-1989, 23.
} 
mechanics, and electrical occupations. ${ }^{275}$ It could be argued that these off-site services were not as supportive of diverse learners as would have been in-house resources.

Alum, parent, and former school board member Kay Hadjokas exclaimed about Aquin that it was "tremendous the incredible lives that came out of there - surgeons, a professor, and others. ${ }^{276}$ While Aquin's demographic data showed little change in the ethnic or racial composition of the student body, it is worth noting that the "ethnicity" categories offered only one option for students of European descent - "white."277 This was indicative of an era different than that of the early history of Catholic schools in America. Catholicism, long the immigrant religion, had "grown up" so-to-speak, and Catholic schools of the later twentieth century were focused on college preparation of their students. One anecdote to highlight such modernization was a new "Enrichment" program at Aquin in the 1979-80 school year, which offered a computer programming course taught on three new, prized Commodore micro-computers that were acquired by "generous" community donations. ${ }^{278}$ The information age may have appeared to arrive slowly at Aquin, but the Catholics were, indeed, on the move.

Appleby argued for the historical merits of "examining Catholics on their own terms," and "striving to understand the relation between agency and the internal dynamics of Catholic thought, practice, belief, and behavior."279 Whereas McClay’s essay in the same work emphasized a loss of Catholic identity, Appleby underscored

\footnotetext{
${ }^{275}$ Veritas, Aquin High School yearbook, 1980, 51. According to Alum and superintendent Kathy Runte, Veritas (Latin for "truth") was the Dominican motto, and the yearbook name, then, possibly came from the Dominican sisters of Sinsinawa, Wisconsin who taught at AHS. Additional reflection from interviewees at the Diocesan Office offered, also, that Veritas was a term in fairly common use by many Catholic organizations.

276 Hadjokas.

${ }^{277}$ Enrollment documents, Aquin papers.

${ }^{278}$ Veritas, 1980, 55.

${ }^{279}$ Appleby and Cummings, 159.
} 
"Catholics' insistence on sustaining their own 'strange' cosmos" of religious imagination and sacramental lens on the world. ${ }^{280}$ He located irony not in a loss of Catholic identity but in that Catholics' hold on their sacred practices and modes of thought were equaled by their "ardent desire to become fully American and to be accepted as such." ${ }^{281}$ Thus, according to Appleby, to understand American Catholics historically, one must "rightly privilege their religious consciousness" as a matter for consideration in such study. ${ }^{282} \mathrm{He}$ asserted that historical study of "lived theology" is "an important explanatory dimension., ${ }^{283}$ He continued to insist that while “liberal, 'enlightened,' post-Vatican II Catholics" were reasonably relatable, the "antimoderns who stubbornly refused to forget their contrary, supernaturalist past" prove a more "formidable challenge." ${ }^{284}$ However, with regard to any target study group, "historians are at their best when they try to inhabit the lives of, and develop a measure of empathy for" the historical figures. ${ }^{285}$ An obvious jumping off point for this study on Freeport Catholics at Aquin is to underscore that, like many American Catholics, they held to their sacramental practices even as they created or were affected by cultural change.

The "American Council Fathers" at the Second Vatican Council "were quick to point out that Italy was where the people voted for the Communist Party and did not go to church, but in America, Catholics - living among Protestants, Jews, and nonbelievers actively supported their church." 286 The Declaration on Religious Freedom (nicknamed the "American Decree") recognized "religious pluralism" as "a fact" of the modern

\footnotetext{
280 Ibid.

281 lbid.

282 Ibid.

283 Ibid., 163.

284 Ibid., 164.

285 Ibid.

${ }^{286}$ Hunt and Walch, 100.
} 
world. ${ }^{287}$ Further, Vatican II made an "implicit declaration that true faith can occur only as a result of a reasoned choice by an informed conscience" and emphasized the importance of "an active social responsibility to promote the greater good." 288 Of American men born in the 1920s, eighty percent became military veterans, and "war gave that generation a confidence that made them wary of churchy paternalism.. 289 Additionally, the wartime experiences of men in combat and women on the home-front taught them that "Protestants and Jews and even atheists shared their fears and aspirations. ${ }^{, 290}$ Moreover, the ethnocentricity and genocidal atrocities of Nazi Germany motivated an emphasis on multicultural imagery in U.S. propaganda, which replaced the previous Catholic notion to forbid "joint ventures with Protestants and Jews." ${ }^{, 291}$ Instead of taking pains to make clear that all religions were not equally valid, Catholics had too many experiences that taught them otherwise. ${ }^{292}$

There was an "increasing divergence of beliefs and attitudes among Catholics" as a result of Vatican II and "Pope Paul's encyclical on birth control."293 A 1968 anonymous survey of 114 freshman at a Catholic university reported that even before the Pope's encyclical, only twenty percent of those surveyed were "firmly convinced that contraception was wrong" (down from fifty-two percent in 1964), and fifty-three percent reported holding a strong belief that "sexual intercourse outside marriage was wrong" (a decrease from seventy-three percent in 1964). ${ }^{294}$ However, a large majority responded

\footnotetext{
287 Ibid., 100-101.

288 Bryk, Lee, and Holland, 147.

289 Hunt and Walch, 30.

290 lbid.

291 Ibid., 31; McGreevy, Catholicism and American Freedom, 204.

292 McGreevy, Catholicism and American Freedom, 204.

${ }^{293}$ Reverend Robert Campbell, O.P., Spectrum of Catholic Attitudes. (Milwaukee: The Bruce Publishing Company, 1969), v.

294 Ibid., 187, 191.
} 
that they believed, still, in some of the traditional teachings of Catholic Christianity - that "there is a hell and that some people go there" (sixty-three percent; yet, a drop from eighty-five percent in 1967) and honored, still, "the Virgin Birth of Christ Jesus" (seventy-four percent; prior comparison data not provided). ${ }^{295}$ Catholics were not abandoning their faith, part and parcel, but to an increasing degree were acting on their individual consciences. Campbell contended that this "trend away from orthodoxy" is a "result of a new approach" to religious education that "emphasizes social values more and doctrine less." 296 One could argue whether the change in religious education was the cause of the social-religious attitudes, or the reverse. Had the changing culture necessitated an adjustment in religious instruction? Likely, it was a mutually-reinforcing cycle of changing cultural values and norms and adaptations in religious instruction. In the introduction to Appleby and Cummings' Catholics in the American Century, John T. McGreevy reported that "by the 1980s" Catholics "were (only) slightly less supportive of legal abortion than other Americans but otherwise virtually identical in their use of contraceptives, approval of divorce and remarriage, and support for rights for gays and lesbians."297 According to "topic " $\mathrm{C}$ ", in the list of content for the unit on "Human Sexuality" at Aquin High School, the 1988-89 Health curriculum included teachings not only on abstinence from premarital sex, but also lessons on contraception. ${ }^{298}$ In his essay Robert A. Orsi claimed that "Catholics engaged modernity actively," but did so "askew to the dominant culture."299 The earlier "cult of the saints," "celibacy of vowed religious," and "the way Catholics used holy oils and waters" continued to be "objects of

\footnotetext{
295 Ibid., 187-188, 191.

${ }^{296}$ Campbell, 190.

${ }^{297}$ Appleby and Cummings, 5.

298 NCA 1988-89, 39.

${ }^{299}$ Appleby and Cummings, 15.
} 
morbid fascination" for non-Catholics," because they remained central to Catholic practices. $^{300}$

Catholic schools provided an additional institution by which Freeport Catholics could organize themselves. The school served as the locus of a micro-community within the city much like the way schools in the early twentieth century "acted as unifying" force for neighborhoods. ${ }^{301}$ Yet, The Declaration on Christian Education (1965) from the Vatican made clear they should not be private enclaves; the document "defined a more active and humane role for Catholic schools - that of "making schools respond to the spirit of freedom and charity."302 Further, the Congregation for Catholic Education's The Catholic School (1977) "further defined the mission of schools in the post Vatican II period" - that they should be "communities with a goal of providing service to society." ${ }^{, 303}$ The schools were tasked with instilling "an appreciation of cultural diversity and pluralism" and reaffirming "the dignity of the person." "304 The NCA committee on Aquin in 1974 reflected the emphasis on local government and social problems with the requirements of sophomores to participate weekly in sessions on "Community Identity" and of Juniors to participate in "American Identity."305

Walch explicated Philip Lampe’s San Antonio study of Mexican American children as evidence of the post-Vatican II emphasis on social justice and ecumenicalism: Hispanic "parish school students were more likely to have non-Hispanic friends, were more willing to date outside their own ethnic group, were more willing to identify with

\footnotetext{
300 Ibid.

${ }^{301}$ Hunt and Walch, 207.

${ }^{302}$ W.F. Przygocki. "Teacher Retention in Catholic Schools," Catholic Education: A Journal of Inquiry and Practice, 7 (4). http://digitalcommons.Imu.edu/ce/vol7/iss4/8. (accessed February 22, 204).

303 Ibid.

304 Ibid.

${ }^{305}$ NCA, 1974.
} 
the WASP value system, showed significantly less prejudice against other ethnic groups, and were more willing to fulfill their civic duties such as voting, military service, and obedience to the law."306 This sort of tolerant spirit seems to have made Aquin, perhaps, an increasingly inviting place in the mid-1980s, because the number of non-Catholic students at Aquin roughly doubled, reaching 43 of 176 total students (24\%) compared to $19(11 \%)$ at the start of the decade. ${ }^{307}$ The schools were still very much "Catholic," but the new Catholicism underscored the common good for all of humanity, reaching beyond one's Catholic boundaries. At Aquin, Principal Cathy Finch was quoted in the 1986 yearbook in her send-off to the seniors, "The result of your study during the past four years should manifest itself as you take your place in the world . . . Be true to your God, your country, your fellow human beings, and yourself., 308

All of this may have begged the question, then, whether or not Catholic schools were needed at all. There was a common argument that Sunday school programs (Confraternity of Christian Doctrine classes -- "CCD") could adequately teach the faith to children. However, Blum argued in 1969 that "if we remove religion totally from the school life of children, we, in effect, teach them that religion is unimportant and irrelevant to life." ${ }^{309}$ Walch offered that "Parents were attracted to the religious environment of parish schools, and one principal proclaimed 'Religion is more caught than taught.",310 "Through liturgies, retreats, and community service programs, the

\footnotetext{
${ }^{306}$ Walch, 202.

${ }^{307}$ Enrollment Documents, Aquin papers.

${ }^{308}$ Veritas, 1986, 16.

${ }^{309}$ Blum, 31.

${ }^{310}$ Walch, 236.
} 
Catholic school" reinforces "the idea of membership and social responsibility within a larger community. ${ }^{311}$

In response to the declining enrollments begun in the late 1960s, however, McCluskey argued that "if the Catholic community were truly convinced that the separate Catholic school system was the necessary way to pass on the faith to the next generation, then they would find the money. ${ }^{312} \mathrm{He}$ contended that the financial challenges the schools faced were merely symptomatic of the decline of the relative value of Catholic education as perceived by Catholic parents. Yet, based on the middle class, and often blue collar, status of many Aquin families, it seemed that there were some Catholics who did value Catholic education, as they were clearly willing to sacrifice for their children's tuition and the school's survival.

According to Orsi, "Catholics of the 1960s and 1970s" felt a "radical break from the past" in terms of earlier Catholic devotionalism: the "novenas and rosaries, graphic crucifixes, relics and holy cards, endless rounds of prayers and pains offered up for the souls in purgatory." 313 It was by these "practices" that "Catholics interacted with the supernatural, which they took to be present to them in the circumstances of their everyday lives. ${ }^{314}$ It seemed some of these methods had become relics of a Catholic past. However, religious education had a new relevance.

By the 1980s, scientists had advanced the space program from the 1960s moon landing to a "reusable space shuttle" and the 1948 "invention of the transistor" created "phenomenal computational speed," which had "profound social and economic

\footnotetext{
311 Ibid., 137.

${ }^{312}$ McCluskey, 281-282.

${ }^{313}$ Appleby and Cummings, 12-13.

314 Ibid.
} 
consequences" that only quickened as the decades rolled by. ${ }^{315}$ Those sorts of technoeconomic advancements clearly had life-altering significance in the way Americans conducted their daily lives - from the jobs they did and how they carried them out to the way friends and family kept in touch with each other. While such change introduced new social and moral challenges, the most obvious dilemmas arose as a result of the increased "technical mastery of biological and medical techniques." 316 How far should humans go to unlock the mysteries of the human gene pool and what uses of such information were ethical?" Who got to decide? "What principles should govern" human organ transplants, artificial insemination, or situations of surrogate motherhood? ${ }^{318}$ The 1984 graduation speaker at Aquin High School, alum Pat Cunningham, spoke to new and changing threats, particularly that of nuclear war, and validated the relevance of Catholic education in modern times - that "if the man is right, the world will be right." 319 While regular awareness of gender-inclusive language appeared to be, yet, on the horizon, he spoke to the strength of Aquin - the persistent moral instruction and spiritual development of its students.

As of 1980, Aquin still held daily mass at 2:40pm, and the 1988-89 report on Aquin by NCA indicated that there was a good "variety and frequency of faith experiences provided." ${ }^{320}$ The first impressions Aquin made on Cathy Finch were that the school had "good people, good kids," and that Aquin had a clear and positive influence on the students. ${ }^{321}$ The Catholicity of the school was strong. ${ }^{322}$ Annual, spring-

\footnotetext{
${ }^{315}$ Kennedy, Bailey, and Piehl, 654-655.

316 Ibid.

${ }^{317}$ Kennedy, Bailey, and Piehl, 654-655.

318 Ibid.

${ }^{319}$ Veritas, 1984, 110.

${ }^{320}$ Ibid., 1980, 55; NCA report 1988-89, 8.

${ }^{321}$ Cathy Finch.
} 
time, junior and senior class overnight religious retreats emphasized Catholic prayer, personal reflection, and team-building activities. ${ }^{323}$ The evening of the 1986 senior retreat concluded, as described by the yearbook staff, "following tradition" with ghost stories told by the retreat "padres" (priests). ${ }^{324}$ There was a more relaxed interaction between clergy and laity, even between clergy and adolescents, as Catholic education reached a new generation.

Among the community service projects of Aquin students was one that bridged the generations. A few of the high school kids crossed Galena Avenue each day around 8:00 a.m. to help some of the elderly nursing home residents make their way to mass in St. Vincent's chapel. ${ }^{325}$ Hadjokas recalled the relationship Aquin had with St. Vincent's when she was a student, and later, as a young mother, she could not wait for her girls to have that experience of service. ${ }^{326}$ For her, it was all about making connections and building community.

\footnotetext{
${ }^{322}$ Ibid.

${ }^{323}$ Veritas, 1986, 108.

${ }^{324}$ Ibid.

${ }^{325}$ Cieslak.

${ }^{326}$ Hadjokas.
} 


\section{CHAPTER V}

\section{SURVIVING THE 1970s AND 1980s, THE VIEW FROM THE SUBALTERN,}

\section{PART II}

According to Wilfred M. McClay, the U.S. progressives of the early twentieth century found it "pointless" to "attempt to restore the small-scale community of days past," and that "economic and social modernity had rendered such community, with its personal bonds and face-to-face business transactions, obsolete." ${ }^{\text {,27 }}$ An intimate, preindustrial paradigm for social structures was deemed irrelevant, and John Dewey and other progressives attempted a "new social order" that they hoped would marry the industrial era to a renewed sense of the common good. ${ }^{328}$ However, "the rise of totalitarian regimes in Europe" stirred in Americans "doubt of any system that would emphasize the group over the individual, however nuanced the emphasis and sensible the reading." 329 For Catholics, however, "the basic tenets of Catholic social thought" pivoted on several "desiderata," notably "the dignity of community life grounded in respect for the common good" and "a deeply communitarian understanding of the human person and on the primacy of the natural family as the "first and fundamental structure"" of

\footnotetext{
${ }^{327}$ Appleby and Cummings, 145-146.

328 Ibid., 146.

329 Ibid.
} 
society. ${ }^{330}$ This mindset recalled some of the earliest days of Catholic education highlighted earlier and also set the stage for the late twentieth century Catholic schools. They could be seen metaphorically as preindustrial, communal societies that were forged, ironically, in the industrial era, and as a matter of necessity for their school's survival, continued their intimate, relational flavor even into the post-war, post-industrial period.

\section{In Parish School: American Catholic Education from Colonial Times to the}

Present Timothy Walch reminded that "the most important theme - one that pervades the history of Catholic education from its earliest days - is sacrifice."331 Furthermore, he quoted C. Albert Koob from a National Catholic Education Association (NCEA) meeting in the 1960s, "At times of crisis the adrenaline flows more abundantly in the human system and men are strengthened beyond normal. At times of crisis, leadership emerges and forces gather for mutual support to further the common good." ${ }^{332}$ Harnessing daily their personal and collective stamina to preserve the subculture of their "Aquin family," one could have said of the AHS community that they were a "tribe."

\section{L.S. Stavrianos offered in Lifelines from Our Past that hunting and gathering} societies exhibited a "generalized form of reciprocity,"and because this sharing ensured physical survival, "cooperative kinship relations" were dominant patterns "through almost all of human history."333 "Individual accumulation" of goods was "impractical" for their nomadic lifestyles and the unreliability of individual food gathering efforts could have threatened starvation for different folks at different times. ${ }^{334}$ Hence, survival in communal cultures necessitated habits of continual sharing between the members of the

\footnotetext{
${ }^{330}$ Ibid., 151.

${ }^{331}$ Walch, 21.

${ }^{332}$ Ibid., 179.

${ }^{333}$ L.S. Stavrianos, Lifelines from Our Past: A New World History. (New York: Pantheon Books, 1989), 1921. ${ }^{334}$ Ibid.
} 
large clan groups and placed value on generosity. ${ }^{335}$ Political power rested with persons of experience with practical survival skills, such as hunting, and with elders who taught the young by example and oratory. ${ }^{336}$ Aquin families of the 1970s and 1980s were clearly modern and sedentary, situated within the Rockford Diocese of 105 parishes in seventy-two towns, spread across eleven counties from the Mississippi River in the west to the Fox River Valley at the edge of Chicago in the east. ${ }^{337}$ Yet, this tiny school was reliant on the generosity and guidance of elders and cherished their legends and traditions.

Within Dave Egger's historical fiction, What is the What, his Sudanese protagonist, Valentino Achak Deng, recounted his father's telling of the creation story. ${ }^{338}$ He explained that God had given the first man and woman of their Monyjang tribe cattle that would "bring them milk and meat and prosperity of every kind."339 "God said, 'You can either have these cattle, as my gift to you, or you can have the What." ${ }^{340}$ When the "first man" asked "What is the What?" God replied, "I cannot tell you. Still, you have to choose." The man "chose cattle."341 God had tested "the man to see if he could appreciate what he had been given, if he could take pleasure in the bounty before him," and Valentino recalled that his father often told that "the What" had been given to persons outside of Africa who measured prosperity by the acquisition of material goods. $^{342}$

\footnotetext{
${ }^{335}$ Ibid.

${ }^{336}$ Stavrianos, 25, 35.

${ }^{337}$ Cieslak.

${ }^{338}$ Dave Eggers, What is the What: The Autobiography of Valentino Achak Deng, A Novel. (San Francisco: McSweeney's, 2006), 62-63.

339 Ibid.

${ }^{340}$ Ibid.

${ }^{341}$ Ibid.

${ }^{342}$ Ibid.
} 
Aquinites had been bitten by the same consumerism as other post-war Freeporters, but maintaining their intimate Aquin subculture motivated frugality and material sacrifice. Unlike most of the other schools in the sports conference, Aquin offered a muddy, pot-holed, gravel lot for parking, a most modest of tracks -- spraypainted lanes of grass, and in the rainy season, the inside hallways offered an obstacle course of five-gallon buckets catching internal leaks from the roof. ${ }^{343}$ Whereas visitors likely viewed all of this with a touch of disdain, this type of making do was normative to the Bulldogs. ${ }^{344}$ After all, there was not any money available to resurface, upgrade, or replace the facilities. The 1982 NCA report on Aquin indicated "an enormously strong sense of school community" and that "intense loyalty by parents, students, and graduates to Aquin is very evident . . . they have a good thing at Aquin and they'll fight to keep it."345 They would not discard Aquin in exchange for "the What."

While enrollment numbers were declining at Aquin High School, there was a simultaneous, symbolic shift within American culture with regard to group identity that dove-tailed with Aquin's ideology. Americans developed, according to historian Bruce Schulman, a "profound disillusionment with the corruption and inefficiency of public institutions" and "the conception of a national community" was replaced with "the private sphere." 346 People were on "a quest for personal fulfillment within a small community."347 A 1970 study of fifty-four Catholic schools across the country found that "the requirement in many schools of active parental participation" seemed to "foster among parents an exceptional loyalty to the school and a willingness to make

\footnotetext{
343 Observations by the author.

344 Ibid.

${ }^{345}$ NCA, 1974.

${ }^{346}$ Schulman, xv.

347 Ibid., xvi.
} 
extraordinary sacrifices on its behalf. Parents identified with parochial schools as their school whether they were Catholic or not." ${ }^{348}$ Among the "intangibles" Father Michael O'Neill emphasized as the "the real economies of Catholic education" at the 1981 NCEA meeting, he suggested spirit, morale, and personal relationships between school, staff, and clients." 349

That "We Are Aquin" had been the ubiquitous battle cry at ballgames and used frequently on building art and promotional mailings symbolized the complete personal investment of the families of the children who attended Aquin. "The people wanted Aquin to be open; they would do anything," said former Diocesan Superintendent of Schools Sister Joella Miller, "It was a big family where everybody was taking care of everybody." ${ }^{350}$ She "loved going there," as she was "always so welcomed. People would pour me a cup of coffee and sit down with me and want to talk." 351 Aquin had a particularly "intense spirit" due, in part, to its small size. ${ }^{352}$

Bryk, Lee, and Holland noted that when they "entered their field-site Catholic schools," the school personnel and "students immediately identified them as guests and greeted them with friendliness and hospitality. The school buildings and campuses were clearly not public places, but were 'owned' by the students and teachers, who welcomed us into their home. ${ }^{353}$ Father Beauvais, a strong advocate of lay leadership, respected the determination of the Aquin people and that they really bent over backwards in a family effort to give of themselves to the kids -- from fundraising endeavors to creating a

\footnotetext{
${ }^{348}$ Walch, 203.

${ }^{349}$ Walch, 227.

${ }^{350}$ Sister Joella Miller, O.P.

351 lbid.

352 Ibid.

${ }^{353}$ Bryk, Lee, and Holland, 128.
} 
"lovely environment." 354 During his few years teaching at Aquin and in the subsequent years in his work for the diocese, it was apparent to Beauvais that Aquin "was not only a high school, it was a community;" it was a "healthy, warm place," and "that is a testament to the people." 355 When Mike Cieslak assisted with a survey for a growing parish across the diocese, on the eastern side, he found it interesting that the "longtimers" of that school commented about it with "warmth and nostalgia," whereas newcomers to that town thought of the same school as a bit of a "dump." "356 He told that story to illustrate that what we value cannot always be measured in terms of material elements such as aesthetics, modernity, or efficiency and that the value of some Catholic schools lay in how invested a person is in the creation of the place as one's home. ${ }^{357}$

Historian Michael Kammen recognized that the deliberate invention of tradition and molding of collective memory has been a strong "cultural manifestation" since the late 1700 s, and he suggested that "an exploration of traditions in a particular cultural context may help us to determine the underlying basis of a community's or a nation's sense of identity." 358 While he claimed America faced a central tension between being a nation of "progress" and desiring a sense of "tradition," Aquin, too faced the challenge of reconciling these two, conflicting ideals. ${ }^{359}$ Additionally, particular subcultures, such as people of a particular "religious affiliation" faced a tension between particular traditions and those of the nation. ${ }^{360}$ Let us take a closer look inside of Aquin where we see, also,

\footnotetext{
354 Beauvais.

355 Beauvais.

${ }^{356}$ Cieslak.

357 Ibid.

${ }^{358}$ Kammen, 4, 7.

359 Ibid., 700.

360 lbid., 8.
} 
yet another America example of the struggle between contradictory ideals of "innocence" and "power" - both of the group collective and within individuals. ${ }^{361}$

If one was to peruse the school's yearbooks from the 1970s and 1980s, it would be fair to surmise that it was, at times, a rowdy household. The seemingly ill-advised senior class "Looking Back" page at the end of the 1982 yearbook, for example, included references to "V.D.," "Queef," several uses of a derogatory term for homosexual men, and, among several more questionable quotes, "Party hardy, drink a brew, we're the class of ' 82. ." 362 The same page in the 1985 book includes "How come no one was wasted at the Homecoming Dance" and "Strip poker anyone." safety and emotional security within the insular confines of a small place in which everyone knew very well everyone else, there was also such a trust in that security that a "kids will be kids" attitude seemed to prevail. The 1984 "Looking Back" included this telling note "Drinking at Aquin? (shhh, don’t tell anyone)."364

Kathy Runte offered that Aquin kids in the post-war era were "rowdier" than in the first half of the twentieth century, but "weren't tempted by some of the later (1990s/2000s) culture issues (drugs, drinking, casual sex, etc.). So, students skipped school and played pranks. ${ }^{\not 65}$ Speaking to the 1970s and 1980s, specifically, Bill Pospischil empathized that "kids are always kids," but that there seemed to be a shift in parents losing some of the respect from kids. ${ }^{366}$ Providing anecdotal context beyond the walls of Aquin, three veteran teachers at a rural public school in Illinois underscored that in the 1980s fewer rules were necessary and the students were "into less serious stuff and

\footnotetext{
361 Ibid.

${ }^{362}$ Veritas, 1982.

${ }^{363}$ Veritas, 1985.

${ }^{364}$ Veritas, 1984.

${ }^{365}$ Runte.

${ }^{366}$ Pospischil.
} 
problems" than in later decades. ${ }^{367}$ One may speculate, therefore, that the 1980 s may have been a transition point at which a more free-spirited precedent of school supervision and policies coincided with an increase in some of the more "serious" student behaviors. As evidence by the yearbooks, Aquin students appeared not to have been necessarily more prudent than students in the public schools.

However, Cathy Finch described Aquin as "small, comfortable, and very low key with well-behaved kids."368 So, perhaps, the Aquin students were not necessarily less prudent than the public school kids, and, like Pospischil indicated, they were typical teens. There appeared to be a cultural difference within the Aquin "home," however. Finch said "It was really a middle class school of hard-working people who wanted more for their kids," and in the case of Aquin, "more" meant daily instruction and reinforcement of Catholic values and personal morals. ${ }^{369}$ It was her impression that "tuition was a lot lower than other Catholic schools," and Hajokas recalled financial worries and the blue collar culture of Aquin that was perceived as unlike the much larger school in Rockford, "Boylan, that gem over there."370 She remembered her days as a student at Aquin and recalled that it was a place of "smallness and closeness where everyone was very personally connected, and there was tremendous pride."371 "People took pride, just, in the name "Aquin." She offered that for the students, it was probably a "sports thing," as the school competed with relative success for its small size, but for adults, it went beyond athletics. ${ }^{372}$ The Aquinites had a "driving desire to keep the school going - everybody worked up there: puttying windows, putting on the F.A.C.E.S dinner

\footnotetext{
${ }^{367}$ Informal interviews by author in the teacher's lounge of a rural school in Illinois.

${ }^{368}$ Cathy Finch.

369 Ibid.

${ }^{370}$ Hadjokas.

371 Ibid.

${ }^{372}$ Hadjokas.
} 
show fundraiser," to name a few volunteer efforts. ${ }^{373}$ "It was so, so much work!" Kay cooked the Greek food from scratch and enlisted her friends, Kathy Runte and Cathy Finch to paint Greek wall murals and make hand-made tablecloths. It was "two weeks of all-day, all-night work.” From cheese and sausage sales to BINGO concessions and the colossal rummage sale, Aquin families put in plenty of "elbow grease." Indeed, according to scholar John B. Huber, the middle-class socioeconomic status of Catholic school families held true until the 1990s. ${ }^{374}$

Bruno V. Manno (U.S. Dept. of Education) made clear that the notions of Catholic schools as "havens for whites fleeing public education or for elites avoiding social responsibility" seem to have been false stereotypes, as Catholic schools tended to have "less internal economic and racial segregation than the public schools.",375 Moreover, those schools in the large cities where one might presume "white flight" to have driven whites into Catholic schools, there were great increases in the enrollment of African American children from 1970 to $1984 .{ }^{376}$ Because Freeport was a small town, it did not undergo the same demographic shifts as was seen in large city centers and associated suburbs. Thus, some of the trends in urban Catholic schools do not hold true for Aquin, yet Aquin yearned for a larger student population and welcomed everyone.

Runte stated that many Aquin families had been attending the school for several generations. According to the U.S. General Accounting Office, as reported by Lisa Melman Hienlein and Marybeth Shinn, "The United States has one of the highest mobility rates of all developed countries - about one fifth of all Americans move

\footnotetext{
373 Ibid.

374 John B. Huber, "The Accessibility of American Catholic Secondary Schools to the Various Socioeconomic Classes of Catholic Families," Catholic Education: A Journal of Inquiry and Practice. http://digitalcommons.Imu.edu/ce/vol10/iss3/2 (accessed May 4, 2014), 273.

${ }^{375}$ Walch, 240.

376 Ibid., 239.
} 
annually." ${ }^{377}$ The United States Census Bureau reported mobility rates in terms of fiveyear blocks, and the mean rate from 1965 to 2010 was approximately forty-one percent of U.S. citizens had moved. ${ }^{378}$ While 1970s and 1980s data for Aquin legacies had not yet been completed by their archivists, of the 2013-2014 student body, 36 percent were children of Aquin alumni, with 9 percent third generation Aquinites, and nearly 5 percent representing the fourth generation of their family to attend AHS. ${ }^{379}$ Tim Smith added that the tight-knit "family" of Aquin may not be "an easy place to break into, but people do." Additionally, Smith concluded that Aquin had not really changed much, but there were "rough times depending on the flavor of each senior class." Students shared in what might be analogous to "sibling rivalries" as well as a sense of personal entitlement in their small school community, and these dynamics posed challenges - more at some times than at others and more profoundly for some students than others. ${ }^{380}$ The many interviewees concurred that the intimate climate worked well overall to sustain the community even when numbers dropped and finances were strained. Tim suggested that "the whole key that turns the whole thing is the family. When you lose the family, you lose the whole structure. ${ }^{381}$

The NCA committee on Aquin in 1974 indicated "the school size permits students to attain an identity as an individual which is denied many students at larger schools. ${ }^{״ 32}$ The 1998-1999 NCA committee identified a teacher-to-student ratio at Aquin of 9:1, and

\footnotetext{
${ }^{377}$ Lisa Melman Heinlein and Marybeth Shinn, "School Mobility and Student Achievement in an Urban Setting," Psychology in the Schools, Vol. 37(4), 2000.

${ }^{378}$ David K. Ihrke and Carol S. Faber, "Geographical Mobility: 2005 to 2010," U.S. Department of Commerce Economics and Statistics Administration of the U.S. Census Bureau. http://www.census.gov/hhes./ migration (accessed May 18, 2014).

379 Aquin papers.

${ }^{380}$ Observations of the author.

381 Smith.

${ }^{382}$ NCA, 1974.
} 
noted the intimacy of the school and that there were a "variety of activities which are available to all students." ${ }^{, 383}$ Success earned by Aquin students appeared not to be due to selective enrollment, but rather, it was attributable of the desperation of underdogs trying to prove themselves. Thus, Aquin's triumphs readily became intra-group legends and provided means by which to reinforce the values of their micro-culture in each new year of freshmen.

The 1981 football state championship over a larger Maroa-Forsyth High School was a particular point of pride. From a consolidated school in Central Illinois, the Trojans wore uniforms that put to shame the Aquin Bulldogs' plain yellow pants, solid yellow helmets, and white mesh jerseys adorned with only bold, screen-printed numbers - no stripes, names, logos, or other ornamentation. ${ }^{384}$ Tim Smith recalled that event with great clarity and referenced it to demonstrate the disadvantages and challenges faced by Aquin. One veteran teacher at Maroa, however, told of the disbelief of her siblings when they visited the small MFHS from their homes in Chicago. They could not believe that, depending on where one parked in the school lot, he or she might find their vehicles drooled upon by cows from the adjacent farm. One could wonder if the cow-neighboring Trojans thought Aquin as much an underdog as the Freeporters believed themselves to be, or if they felt themselves to be of equally humble origins. Five years later, during the 1986 play-offs, (as mentioned prior) Aquin played at the FHS stadium due to adverse field conditions at their home school. The players wore inside their football pads small baggies of Conley Field dirt, and having Aquin's earth with them satisfied the members

\footnotetext{
${ }^{383}$ NCA, 1988-89, 23.

${ }^{384}$ Veritas, $1982,8-9$.
} 
of the Aquin clan. ${ }^{385}$ These football legends appeared to teach two particular lessons within the community, both of which center on the ideal of pride - to have the fight of a Bulldog, and to be proud of home. Herein one can observe Kammen's tensions of progress and power on the one hand, and tradition and innocence on the other. Aquin valued victory while claiming simultaneously its virtue of humble origins.

As one might suspect, the other significant source of AHS folklore revolved around Bishop O'Neill. Father Beauvais admitted of Aquin folks, "They liked to talk about 'Art,' and they probably felt more comfortable with him than people from other places in the diocese might have felt." ${ }^{386}$ Kay (Enzler) Hadjokas, who followed older brother, Jim, to Aquin recalled how "Art kidded that he had a red phone in his office and if it rang it would be" her father, Bob Enzler. Her dad, after all, had been close friends with O'Neill, and Kay knew that he had stayed in close contact with his friend even after O'Neill moved to Rockford and took the helm of leading the diocese. When asked about one of many "near-closure" Aquin legends, Kay said she had not been aware of the tale of her dad making a call upon the Bishop at the metaphorical midnight hour that miraculously kept open "the little school that could" at 1419 S. Galena Avenue. However, to underscore the ecumenical, wise, and pragmatic nature of O'Neill, Kay told the story of when she became engaged to a young man of the Greek Orthodox faith. Because this troubled her father terribly, he sought the counsel of his Bishop friend, and hours later Kay received a call from O'Neill who told her, "It was a three-martini lunch, but I finally convinced your Dad that it will be okay for you to marry Frank in the Greek

\footnotetext{
${ }^{385}$ Pospischil.

${ }^{386}$ Beauvais.
} 
Church."387 O’Neill was a bishop who exemplified the updating of the Church via Vatican II, and his persuasion of Enzler toward ecumenicalism and acceptance is exemplary of the dual pull on Catholics to maintain their traditions while accepting progress in a multicultural society.

Tim Smith followed in his mother's footsteps when he became a member of the school board, and the fact that his father attended Loras College with Bishop O'Neill gave him a personal connection in their working relationship. ${ }^{388}$ Smith also remembered being a mass server (“altar boy”) at St. Thomas parish when O’Neill was the pastor. Smith believed that Aquin's staying open could be credited to the Bishop, "It was O’Neill, there was no doubt about it." He recalled what a great guy O'Neill was and recounted the time he drove over to the Bishop's office in Rockford on a Saturday morning to discuss school business. “O’Neill kicked back and listened with his feet up on his desk." ${ }^{389}$ The fear of the school closing in the 1970s and 1980s was palpable, and Aquin held dear to the hope that the relaxed, understanding Bishop would forever be on their side. The 1981 yearbook celebrated graduation with this caption with one of just four pictures -- "Bishop O'Neill pleased the many friends of Aquin when he remarked, "Aquin is here to stay."' The imperative of the many O’Neill legends was that one should never underestimate the critical significance of nurturing authentic, personal relationships. From the outside, one could observe how this demonstrated the U.S. trend of "decentralized" passing on of memory and tradition wherein Americans, and Aquinites, valued local autonomy in which a heritage or history belonged to and at least appeared to arise from the collective group rather than appropriated by a particular

\footnotetext{
${ }^{387}$ Hadjokas.

${ }^{388}$ Smith.

389 Ibid.
} 
power. ${ }^{390}$ Societies can "persist and individuals survive," according to Kammen, "only by acting as if the world made sense," and so, "communities live by myths, of necessity."391 Kammen argued fervently that America had a "distinctive configuration," and he shared the words of a "student of the Revolution" as anecdote:

It is curious that American myth-making is so unlike the ancient myth-making which as time went on made its gods and goddesses more and more human with mortal loves and passions. Our process is just the reverse. Out of a man who actually lived among us and of whose life we have many truthful details we make an impossible abstraction of idealized virtues. ${ }^{392}$

In the case of Bishop Arthur J. O’Neill, members of the Aquin community kept their legends of him specific and grounded in his humble earthiness, and it was largely the degree of crises or details of impending closure that seemed to circulate in ambiguity. The man, himself, became a legend precisely because of the gritty way with which he trod the ground among them.

In many public schools a "centralized bureaucracy" facilitated "standardization," and "particularisms" were seen "as imperfections needing redress," but in Catholic schools there tended to be a "high degree of autonomy" as "the rationale for activity" within "relies on traditions and local judgments." "393 Fitting for a Catholic community, Aquin was rich in ritual and had a tradition of having traditions. Whether it was generations of students adding their signatures to the art room wall or standard high school events like the spring musical and senior class photo, it seemed anything longer lived than a year or two was dubbed "tradition" and quickly became sacred.

\footnotetext{
390 Kammen, 14.

391 Ibid., 25.

392 Ibid., 17, 27-28.

393 Bryk, Lee, and Holland, 313.
} 
Aquin had its first Homecoming King in the fall of 1985, which is also when principal Cathy Finch designated "Senior Doors" for privileged use only by twelfthgraders. ${ }^{394}$ The student-written passage in the yearbook coaxed, "Memories and traditions hold alot [sic] of value for the students, hoping they'll carry the special memories close."395 In 1986 the seniors studying family life and marriage planned a mock wedding complete with bridesmaids, a faux (student) priest, and cake reception. ${ }^{396}$ Despite the suggestion that this contradicted the course emphasis on the actual marriage, this, too, became entrenched and long-lasting. Additionally, the seniors "cared for" raw egg babies so that students might acquire some degree of understanding of the diligence necessary to tend to children. ${ }^{397}$ While the egg experiment often devolved into studentto-student egg-napping and other high jinks, this, too, became an anticipated annual tradition. $^{398}$

Aquin ended the school-sanctioned "Freshman Welcome" before the start of the 1979-80 school year, and some seniors carried out what appeared to have been a few stints of "unauthorized" soft hazing. ${ }^{399}$ According to the 1971 Veritas, Freshman Welcome had consisted of the seniors dressing up in odd ways (that year as ice cubes) and a number of antics, like raw egg on the freshmen's faces. ${ }^{400}$ It was a planned event that included scheduled time for the freshmen to clean themselves, and the band provided pep music for the revelry. ${ }^{401}$ In 1978 , the event appeared to focus on things like wheelbarrow races and "recitation of the school song" followed by a "pep rally" in the

\footnotetext{
${ }^{394}$ Veritas, 1986, 2.

395 Ibid., 1986, 2.

${ }^{396}$ Ibid., 1987, 86.

397 Ibid., 1986, 115.

${ }^{398}$ Author's direct observations and experiences.

${ }^{399}$ Veritas, 1980, 67.

${ }^{400}$ Veritas, 1971, 70.

${ }^{401}$ Ibid.
} 
gymnasium. As late as 1990, unauthorized "welcoming" continued, and so, even when the officials declare a tradition as bust, they persisted, if even in fainter forms.

How integrated are the parts of family life that even a fundraising event, the televised and radio broadcast Bids for Bulldogs, quickly became an annual tradition. Begun in 1977, it enlisted students and parents to solicit donations from local businesses, and on the day of the auction, to serve as on-air phone workers and behind-the-scenes runners. The remaining members of the Aquin community watched and listened from home not only to bid, but also to be sure not to miss any on-air happenings or mishaps. In the era before Facebook, email, or Twitter, this event was as personal as media got Aquin was on the television!

The annual ring ceremony was a much-anticipated event in the winter when each junior was presented his or her class ring by a personally chosen senior, and this was carried out during a special, all-school mass at St. Vincent's. ${ }^{402}$ It began with a procession of the juniors through the center aisle flanked by the seniors. ${ }^{403}$ A lit candle, as a sign of peace, was presented to each junior as they received their ring, which was described as a symbol of unity within each class and the ceremony as celebration of the friendship between the two classes. ${ }^{404}$ Apparently, however, most schools in the Rockford Diocese also had ring ceremonies, and even a cursory Google search revealed that a number of private schools and universities have such rituals, as well. ${ }^{405}$ It served as a quintessential Catholic school rite of passage into the ranks of the upper classmen.

\footnotetext{
402 Ibid., 1986, 10.

${ }^{403}$ Ibid., 10.

${ }^{404}$ Veritas, 1986, 10.

${ }^{405}$ Cieslak.
} 
While many of Aquin's so-called traditions were similar to customs in many other American high schools, they served the purpose, nonetheless, of internal unity, institutional social structure, and personal rites of passage. There was, however, one tradition at Aquin High School for which they received a fair amount of media attention - the annual Prom Draw. It had been a mainstay of Aquin culture since 1926, and Aquin was "the only school in the country to handle prom this way."406 As long as recent memory served, the lottery system involved the use of an actual bingo dispenser. ${ }^{407}$ "The boys are given random numbers and gather in the library for the big drawing," and when a number is called, the fellow holding that number came forward to select an envelope from the bingo dispenser to learn the name of his date. ${ }^{408}$ One by one, each boy entered the room of waiting girls to formally ask his date to the prom, knowing he would receive an answer in the affirmative. "The nuns at Aquin started the tradition in the late 1920s to help the students socialize through dance," and Aquin "wanted to be sure all students," including those Aquinites from St. Vincent's orphanage across the street "were on an equal social footing for the year-end dance."409 Bill Pospischil, quoted by NBC6.com, explained "We all know - at least in our high school career - we're going to have an opportunity to have at least two dates before we graduate. ${ }^{" 410}$ Every year the hosting "junior class votes to retain the prom draw," and it became the most-anticipated of all events of the school year.

\footnotetext{
${ }^{406}$ Suzanne Richter and Phil Rogers, "Bingo for Prom Dates." NBC6.com, July 12, 2009. http://www.nbcmiami.com/the-scene/archive/Aquin-Central-Catholic-High-School-Prom-Dates-FreeportIllinois-Bingo-Dispenser-Stress.html (accessed March 30, 2014).

407 Ibid.

408 Ibid.

409 Richter and Rogers; Jane Lethlean. "Aquin Prom Draw Steeped in Tradition." Journal Standard, March 30, 2012. http://www.journalstandard.com/x760609986/Aquin-Prom-Draw-steeped-in-tradition. (accessed March 30, 2014).

${ }^{410}$ Richter and Rogers.
} 
According to enrollment documents from the archives of Aquin, 1973-1974 appeared to be the last school year in which a resident of St. Vincent's attended Aquin. ${ }^{411}$ Yet, the prom draw continued for forty years more years (and counting). The entire evening of orchestrated prom events were attended in entirety by everyone -- from predance "Coke-tails" at a student's home and the whole-group dinner at a local venue to the Grand March of the couples into the same auditorium in which that spring dance had been held for all of its 88-year+ history. Once the dance royalty were announced and crowned, the on-lookers departed and it was an evening of teen dancing chaperoned by faculty members. Each fellow presented to his date a dance card on which several of his friends assigned themselves to dance with that particular girl for one of the designated "dance card dances" of the evening. Additionally, the matched prom dates danced together the very first and final numbers of the evening, but otherwise were free to dance with their boyfriends or girlfriends. Tim Smith relayed the story he had often heard that his dad had drawn the name of the same girl two years in a row, and he looked forward to 2015 when his grandson, Colby John, would be a junior and participate in his first drawing. ${ }^{412}$ "It's what makes Aquin, Aquin."413

While tradition and elders reigned supreme in historic, pre-industrial cultures, the youth of the "tribal' type subculture within Aquin exemplified plenty of the typical industrial and post-industrial characteristics of American teenagers: rebellion and entitlement. Their traditions did not necessarily derive from ancient lessons and wisdom from the elders, but sometimes evolved from recent, desirous custom that quickly become perceived as rites of passage. Adolescents could rail against any change in those events

\footnotetext{
${ }^{411}$ Enrollment Documents, Aquin papers.

${ }^{412}$ Smith.

${ }^{413}$ Ibid.
} 
to which they felt entitled, especially when changes were implemented by the nouveauelders (school personnel who were not alumni). At a place like Aquin, any change was perceived not only as an unjust removal of entitlements, but also as a violation of their AHS subculture, as some "rites" had been experienced by several of their older siblings or even by their parents. Thus, it had become sacred. However, while the youth perhaps believed themselves the makers of their own destinies, elders still served as the backbone of the Aquin group.

Cathy Finch recalled that the parents and teachers created for the students within that small school a "strong sense of belonging and of being valued" - "nobody fell between the cracks. ${ }^{\circ 414}$ It was Aquin's own, unofficial No Child Left Behind (NCLB) local-style. The 1974 NCA report on Aquin cited "appalling" teaching loads placed upon the equivalent of fourteen full-time teachers paid out of funds adequate to pay nine. ${ }^{415}$ However, the same report waxed complimentary on the "many services provided children beyond that which one would expect" and that such was "possible only because of the devotion" of the "administration, faculty, and parents." ${ }^{416}$ Moreover, despite the difficult quantity of work and minimal financial rewards, according to the report, the folks at Aquin created a "warmth and student-teacher feeling (that) contribute to a meaningful learning experience." ${ }^{417}$ Eight years later, the 1982 report also highlighted the "devoted cadre of professional staff" who, while "hindered by workloads and financial considerations, exhibited "enthusiasm and dedication" that were "exemplary." "extreme financial limitations," however, must have made it difficult for many teachers

\footnotetext{
${ }^{414}$ Cathy Finch.

${ }^{415}$ NCA, 1974.

${ }^{416}$ NCA, 1974.

${ }^{417}$ Ibid.

418 Ibid., 1982.
} 
to feel secure in providing livelihoods for themselves and their families. Nearly 75 percent of the 1982 teachers had been there four or fewer years, and there had been five different principals between the year 1974 and $1982 .^{419}$ Despite high turnover rate, the NCA report stated "One thing is clear: students here look to staff for role models and find them. ${ }^{, 420}$ Being a teacher at Aquin required sacrifice and dedication of personal resources.

Bryk, Lee, and Holland found in their study that many teachers at Catholic high schools "described their work as a kind of ministry," and they "observed numerous instances of teacher behaviors consistent with these reports," and many "personal accounts from both students and parents provide further corroboration." ${ }^{\prime 21}$ Despite "rather ordinary" instruction and periodic absence of clarity on the personal relevance of particular lessons, students in Catholic high schools displayed "high levels of engagement with classroom activities," and they suggested that the cause was the "quality of human relations within the school." 422 "The communal organization of the school" bred student success. $^{423}$

Danielle Gillespie at CNSNews.com wrote that it was uncommon for the staff at Catholic schools to unionize. ${ }^{424}$ According to Bryk, Lee, and Holland, approximately 20 percent of teachers at the Catholic schools in their study "had graduated from the school at which they were teaching." 425 They noted that "whereas eighty-eight percent of public

\footnotetext{
419 Ibid.

420 Ibid.

${ }^{421}$ Bryk, Lee, and Holland, 97.

${ }^{422}$ Bryk, Lee, and Holland, 99, 127.

423 Ibid, 100.

${ }^{424}$ Danielle Gillespie, "Bid to Unionize Pits Job Security Against Mission of Catholic School," CNSnews.com, 2008. http://cnsnews.com/news/article/bid-unionize-pits-job-security-against-mission-catholic-school (accessed February 22, 2014).

${ }^{425}$ Bryk, Lee, and Holland, 130.
} 
high schools offer tenure, only twenty-six percent of Catholic high schools do so, and that "Catholic high school principals enjoy considerable discretion in the hiring and firing of faculty." ${ }^{226}$ They claimed that this power and freedom was rarely abused, as a teacher's commitment to engage fully in a Catholic school community, and at relatively low wages, was "an asset to the school." 427 Even as late as the 1980s, Catholic school teachers were typically paid "a sum that few considered adequate," and Walch shared the view of William McCreedy of the National Opinion Research Center as originally reported in U.S. Catholic: teachers were "taking virtual vows of poverty when they signed their teaching contracts. ${ }^{, 428}$ As a result, teacher retention could be a problem, and career teachers were typically valued for the longevity of their service. ${ }^{429}$

Often the "approach to student conduct was much richer" in Catholic schools relative to public schools, as they went beyond the "maintenance of minimal social order." ${ }^{, 430}$ A vital lesson was that "You are a member of this community, and your behavior affects others," because "students' failure to give their best efforts belittled both the sacrifices of their parents in paying tuition and also the efforts of their teachers, who were working hard on their behalf., ${ }^{431}$ For students whose parents had to sacrifice much for them to attend a tuition-based Catholic school, "the ultimate educational outcome" was heavily reliant on the school community filling the gaps in the students' previous cultural experiences. ${ }^{432}$ The students "may feel somewhat uncertain about themselves and may not" become otherwise "well integrated into a school life that their more affluent

\footnotetext{
426 Ibid.

427 Ibid., 132.

${ }^{428}$ Walch, 236-237.

${ }^{429}$ Ibid., 236-237; Cathy Finch.

${ }^{430}$ Bryk, Lee, and Holland, 133.

431 Ibid., 134.

432 Ibid., 219.
} 
classmates seem to embrace readily." "433 However, "a simpler instructional program reduces administrative demands and provides more opportunities for social interaction. The constrained academic structure of Catholic high schools promoted greater commonality in student experiences" and "it also structures commonality in work conditions for teachers" by which everyone "in the school attends to the totality of students' experiences." ${ }^{434}$ In larger public schools, by contrast, teachers often identified with their curricular departments, and zones outside of one's academic wing were "public places" that were "someone else's responsibility." 435 W. F. Przygocki synthesized a series of studies and reported that Catholic school teachers tended to view their jobs as personal ministries and were more "committed and collegial than their counterparts in public schools." nurture and develop all of its members." $" 437$

Kay Hadjokas became one of the elders, herself. She remembered that when she was a girl her father would often invite to their house for the holidays a child living in the group home of St. Vincent's, and that she graduated from Aquin with a boy and a girl who had lived there. She believed in what her father taught her about service, and she recounted the times when, as a board member, she met with fellow board member, Tim Smith, in his dairy barn during his 5:30 a.m. bowl of cereal. ${ }^{438}$ Tim recounted Kay’s dedication to Aquin's survival, specifically his recollection of her making a rattling noise under the table one night during a particularly stressful board meeting. When he asked her what she was doing, the noise stopped, and she tossed into her mouth the Tums she'd

433 Ibid.

434 Ibid., 305.

435 Ibid., 305.

${ }^{436}$ Przygocki.

437 Ibid.

${ }^{438}$ Hadjokas. 
secured from the bottle, replying, "I can't take this!"439 Kay's passion and humor were evident as she recounted Aquin tales, concerns, and triumphs like they had transpired just last year. She was a high-energy leader whose aim had been to drive the tribe onward.

The 1985 Veritas was dedicated to Bill "Mr. P" Pospischil for his commitment to Aquin not only as a teacher, but also as a coach for football, wrestling, girls' basketball, and golf. ${ }^{440}$ Pospischil lamented recently that he had been told sometimes he was "too loyal," and "too emotional," but he said he does not know any other way to be. ${ }^{441}$ His eyes grew a bit watery, and he shook it off and admitted that he valued building relationships with the students and "striving to become better together" at sports and as people. Having "real respect" and the "genuine feeling of making a difference and being connected to people" is what drove him through long days, nights, and weekends at the school for over three and a half decades. ${ }^{442}$ He remembered feeling attached to a good number of the faculty when he was a student and he continued to feel grateful for the care and guidance he received when young. ${ }^{443}$ When thinking back on his work at Aquin, he said he loved how they worked to "find a way to fit in each kid." One case-in-point, the author recalled a close friend who was matched via prom draw with a young man who had struggled socially, and Pospischil simultaneously bolstered the young lady and helped to ensure the young man's dignity when he told the girl privately, "I am glad he drew your name, because I know you would treat him kindly."444 This comment was shared in confidentiality with the author in a private setting, which underscored the effect of "Mr. P's" approach in his message as one of trust, validation, and confidentiality. It

\footnotetext{
${ }^{439}$ Smith.

440 Veritas, 1985, 4.

${ }^{441}$ Pospischil.

${ }^{442}$ Pospischil; direct observations of the author.

443 Pospischil.

444 Ibid.
} 
was an effective, positive reinforcement of the behavior he hopefully anticipated of the teenager. He was Aquin's mindful shepherd.

Father Clarence Thennes, an elderly, kind, and gentle priest often said mass for the Aquin students, and he was much loved for his constant smile. ${ }^{445}$ The mastery of his candy-making hobby was highlighted in the dedication of the 1984 yearbook, and a sample of his sweets was one of several symbolic gifts carried to the altar for the 1984 Baccalaureate mass. ${ }^{446}$ Whether it was the grandfatherly tenderness of Father Thennes, the charisma of teacher and coach Mike Curry, the booming voice of Father Eric Barr, or the tireless labors and good humor of parent volunteer Mary Kneller, Aquin was never at a loss for memorable elders.

The older generation instilled frequently in the students not only the sense that Aquin was special, but that so, too, were the kids, themselves. Greeley and Rossi suggested that Catholic schools offered an environment of particularly strong emotional support and security. ${ }^{447}$ Cathy Finch said there was a strong feeling of heritage that "pulled the students and school community together in a sense of belonging and importance" and that this "outgrowth of family gave confidence" to the young people. ${ }^{448}$ While there was a time in the 1980s that Aquin offered rather lax discipline and less academic rigor than had been the norm, that brief time of students having two and three study halls a day was remedied. ${ }^{449}$ She insisted that Aquin students were "challenged morally" throughout their school days as well as in their evening extracurricular events

\footnotetext{
${ }^{445}$ Veritas, 1984, 3; observations of the author.

446 Ibid.

${ }^{447}$ Greeley and Rossi, 234.

${ }^{448}$ Cathy Finch.

449 Ibid.
} 
with their coaches, and so, they formulated earlier than many other teens a "sense of self."

The magic element that ultimately empowered this success of Catholic school systems was leverage. As detailed by Attorney Steven E. Glink, "private schools are not subject to any restrictions in terms of violations of the rights of students. Hence, while a public school may have to prove that its violations are for a higher purpose or stem from its in loco parentis responsibilities, a private school may set limits arbitrarily." ${ }^{450}$ The scholarship on Catholic schools seems to neglect this pivotal fact. While disciplinary infractions were reportedly minor and/or infrequent in the works cited and at Aquin per the multiple interviews, if one follows the logical trail of "what if" with regard to deviant behavior, private schools, including Aquin, had a clear advantage. The ultimate "what if" question arrived at a determination of expulsion, and schools such as AHS, have full leverage to banish someone. This threat of ultimate exile, while a distant one, is real enough to support the entire system of honor codes. With such codes easily created and enforced, the values and norms weave rather easily into effective lessons by way of legends from the elders and manifest, also, in experiential traditions. The intense, tribal culture, itself, then enters a mutually-reinforcing cycle of normative behavior within the clan, as banishment from this "home" would be nearly unthinkable. It was so unthinkable that most students did not contemplate such a thing, and they were unaware that their teachers and coaches were empowered, ultimately by this particular freedom and leverage.

\footnotetext{
${ }^{450}$ Steven E. Glink, "Protecting the rights of students, parents, and teachers," http://www.education rights.com/studentsrights.php (accessed May 18, 2014).
} 
In addition to serving the expectations of their community, students at Aquin benefitted from their dedication to many school programs. Cathy Finch believed the AHS students' intense involvement in so many activities also bolstered their sense of personal stamina. Students at Aquin felt secure to try new tasks, skills, and clubs, and as a result had a greater chance to learn more about who they were as people and to build a more solid foundation from which to head into the "adult world." Cathy's husband, Ed Finch, insisted that "the rigor level (of instruction) is less critical than development of the sense of self, sense of who you were and a better grip of what you wanted to do and how you fit in." ${ }^{451}$ Small schools, such as Aquin, needed students to participate in many activities, and so, instead of being forced to specialize, students were expected to take a chance at a lot of diverse programs. The author recalled that after a few of her friends from high school had visited her dorm for the weekend that a college mate reflected aloud, "People from Aquin know who they are." the habits of faith and the tenacity and grit of spending the high school years overbooked with commitments to a school community and that these influences gave Aquin students a metaphorical anchor. Ed Finch elaborated, "The most important aspect of education is a sense of real accomplishment - to have many opportunities to meet real challenges and to have that embedded in one's identity, to be able to say 'This is what I can do.",453

Catholic practices may have assimilated somewhat to the national culture, changed some of the ways in which Catholics worshipped, and emphasized social justice with an ecumenical spirit; yet, they maintained some of their unique practices and a commitment to community and the common good. So, the tension between the national

${ }^{451}$ Dr. Edward Finch.

452 Observation of author.

${ }^{453} \mathrm{Ibid}$. 
and the particular, that of progress and of tradition, and of power and of innocence were underlying threads of Aquin's creation of history and sense of home. Their collective memory served the purpose of resisting change while achieving respect in a contemporary setting. Ed Finch insisted that "Whatever Aquin does that's right, it's been doing for generations, and no one can come from the outside and change it without ruining it." 454 Their mantra, "We are Aquin" made clear that "Aquin" and "the people" were synonymous, and their chant defied outsiders to challenge them.

${ }^{454}$ Dr. Edward Finch. 


\section{CHAPTER VI}

\section{WHO DID “WE” BECOME, THE VIABILITY AND CHARACTER OF AQUIN IN THE TWENTY-FIRST CENTURY}

One July not too long before the turn of the twenty-first century, Garrison Keillor gave a "Fourth of July Speech" on his "Prairie Home Companion" show on National Public Radio in which he claimed that it is rather "American" to lean in and to tell one's own story, to want to be known. ${ }^{455}$ In that regard Aquin was rather American. Every interviewee contacted for this project readily agreed to participate, the conversations went on at great length, and follow-up email inquiries were answered immediately with lengthy, detailed accounts and extra stories. When responding to a quick, fact-checking inquiry, Tim Smith urged that You tube should be searched for the "My Girl" link to the spring 2014 prom draw event, now held in the gymnasium to accommodate parents, grandparents, and community members who spectate the annual ritual. ${ }^{456}$ His sense of local pride was obvious. Whether on the phone, typing through email, or talking inperson, every person interviewed from the Aquin community divulged their tales, memories, and assessments like open books, and administration willingly handed over school records. The people of Aquin leaned in confidently to tell their version of what

\footnotetext{
455 Garrison Keillor, "Prairie Home Companion," National Public Radio, date unknown.

${ }^{456}$ Smith; "prom draw 2014 . my girl," YouTube video, 4:39, posted by “Laura Diemer," March 20, 2014, https://www.youtube.com/watch?v=Xq8v_JZ_C_A. A second prom draw YouTube entitled "Sister Collins," found at https://www.youtube.com/watch?v=Zd8pTJY9Doo, is a display of self-deprecating humor about Catholic school. The "Mr. Deutsch" and "Mr. Koester" in the group are first cousins to each other, and are nephews of a classmate of the author.)
} 
their community had been.

Michael Kammen recognized that narratives from a singular place may vary, from those who "seek a highly positive image that can be legitimized by reference to a past that narrates a glorious or harmonious civic culture," and "candid dissenters on the other side who take perverse pride in telling 'it' like it really was." ${ }^{, 457}$ As the historian on this project, the author hoped to have been neither, but desired for readers to have found herein a careful weaving of memories from diverse persons not only contextualized from state-wide, national, and global perspectives and in relation to the existing historical scholarship on education and Catholicism in America, but also analyzed to "reveal" Kammen's “dynamic patterns” of American communities. ${ }^{458}$

It may have been difficult for the school's founding members to have imagined in their first meeting in August of 1923 that their new school with an initial tuition of $\$ 2.50$ per month and coal heating would, in a year 2014, have had an annual tuition of roughly $\$ 5,000$ and classes and offices operated with the use of computers, the internet, and email. ${ }^{459}$ The promotional mailing sent at the conclusion of the 2011-2012 school year evidenced the marrying of modern technology with tradition. ${ }^{460}$ The publication itself appeared on par with contemporary works regarding graphics and layout, Facebook logo, and the school's web address. Additionally, an entire page outlined the trial implementation of tablets in Aquin classrooms. They kept in careful balance the tension between progress and power on one hand and tradition and innocence on the other. The front cover boasted, "We warned them. These 18 seniors (from a class of 20 students)

\footnotetext{
${ }^{457}$ Kammen, 38.

458 Ibid, 688.

${ }^{459}$ By Laws, Freeport Catholic Community High School, and Aquin High School Treasurer's Report, Aquin papers; http://www.aquinschools.org; author's observations.

${ }^{460}$ Aquin Catholic Schools newsletter, 2011-2012, Aquin papers.
} 
made 'Beware of Dawgs' a common phrase among their competition. The local papers even said, 'all roads go through Aquin . ..",461 The motivation of this theme was undoubtedly the girls' basketball team who won the Class 1A state championship, and other sports successes were highlighted. This was clearly an era different than, and predicated upon, the passage of the 1972 education laws (including Title IX) two years after which Aquin added to its Girls' Athletic Assocation (GAA) the school's first interschool, competitive track and volleyball teams. ${ }^{462}$ The bottom margin of the cover chided, "And remember - these championships were won by a high school with 104 students. ${ }^{, 463}$ Aquin continued to claim itself the underdog.

On page three of the afore-mentioned newsletter, the recognition of a student for winning a national award concluded with "Some pretty 'big' competition - but as we all know - Aquin is the little school that can!",464 A similar reminder of Aquin's underdog identity was reinforced on the same page when they highlighted students for all-area theater awards - "Aquin is competing with the Freeport High School performers as well as their familiar rivals from the NUIC (conference). ${ }^{, 465}$ The next page explained a fundraising event benefitting an alum who was "undergoing treatments" for cancer, and it was said of her that "she has the fight of a Bulldog!" "466 To further underscore the value Aquin places on "innocence" and tradition, the newsletter listed in their "stats" section that " $80 \%$ of student body has attended Aquin since the $5^{\text {th }}$ grade, most of those since kindergarten," and that of the members of the state championship basketball team, "19 of

\footnotetext{
${ }^{461}$ Aquin Catholic Schools newsletter, 2011-2012, Aquin papers.

${ }^{462}$ U.S. Department of Education, National Center for Education Statistics, "Digest of Education Statistics," http://nces.ed.gov (accessed June 11, 2014); Veritas, 1974, 36, 51-52.

${ }^{463}$ Aquin Catholic Schools newsletter, 2011-2012, Aquin papers.

${ }^{464}$ Ibid.

${ }^{465}$ Ibid.

${ }^{466}$ Ibid.
} 
24 players" and "10 of 14 varsity players" "have been Aquin students since

kindergarten." ${ }^{\$ 467}$ Additionally, the total commitment required of members of the school community was emphasized where they listed that " 12 of 14 Varsity (basketball players) play Volleyball, 1 plays Golf." ${ }^{468}$

While tuition in the new millennium may have been cost-prohibitive for some families in the Freeport area, and thus, a potential problem regarding the church's mission of social justice and service, it did not necessarily result in the school becoming populated by a transfer of wealthy children from the public schools. The intimacy of the school and the importance of maintaining a sense of continuity in tradition reigned as priority for the Aquin people, and another brochure emphasized this with bold placement of these words on the cover: "Join the Aquin Family." ${ }^{469}$ Within this literature, Richard J. O'Farrell shared this about his mother, a 1928 graduate of Aquin: "Following the death of her mother," Mable E. (Zeien) O'Farrell “and her younger siblings were placed in the dedicated care of the nuns at St. Vincent's." next door to Aquin,"” and she recalled that "Bishop Muldoon visited Aquin whenever he could and called each student by name and commented on their parents' sacrifice sending them there. Then he referred to us, at St. Vincent's, as being HIS children and we felt 10 feet tall." Seventy-four years later, the 1996 North Central Accreditation (NCA) report on Aquin assessed that the 114 students "seem happy and exhibit a high degree of school spirit," and that the faculty were "extremely dedicated." 471 There was reportedly "good rapport between students, faculty, and administration" despite "high turnover in

\footnotetext{
${ }^{467}$ Aquin Catholic Schools newsletter, 2011-2012, Aquin papers.

${ }^{468}$ Ibid.

${ }^{469}$ Aquin brochure, Aquin papers. Per the font styles and graphics quality, it appears to have been from sometime at least as late as the mid-1990s.

${ }^{470}$ Ibid.

${ }^{471}$ NCA Report, 1996, Aquin papers.
} 
administration" with a new superintendent or principal every other year. ${ }^{472}$ Teacher turnover was also a concern. ${ }^{473}$ Despite the low pay and heavy workloads, those Catholic school teachers who remained appeared still committed to their mission of mentoring adolescents in a faith-based school community.

In 2014 Aquin alum and long-time teacher, Bill Pospischil, still loved connecting with students and families, but worried that there was "more distance," a loss of "relational elements" and "face-to-face" interaction. ${ }^{474}$ It seemed to him that societal norms became too focused on quantifiable results and appearances than on relationships. The technological advances were one example of the speed of change in an increasingly global culture, and Superintendent Kathy Runte suggested that modern communications technology could be a double-edged sword. ${ }^{475}$ Social media opened up institutions to public, viral criticism if and when members posted negative thoughts or feelings that previously would have been discussed more privately. ${ }^{476}$

Aquin entered the digital age, the painted grass track and substandard equipment were replaced at the high school level with baseball and softball teams, and the gravel parking lot blacktopped. ${ }^{477}$ However, the annual homecoming mass, class ring ceremony, and prom draw continued, and Aquin still dictated that "boys' hair" must be "above the collar and ear" and that students "may not have gum during mass." 478 The reintroduction of school uniforms harkened back to the 1970s and earlier, and alum Kay

\footnotetext{
472 Ibid.

473 Ibid.

${ }^{474}$ Pospischil.

${ }^{475}$ Runte.

476 lbid.

477 Author's observations.

${ }^{478}$ Smith; Author's observations; Aquin Catholic Junior Senior High School Liturgical Celebrations 20092010, and Aquin Catholic Junior Senior High School Student Handbook Summary 2009-2010, Aquin papers.
} 
Hadjokas responded to that news with delight, exclaiming that "you dress for what you're doing; it sets the tone," and she then added that uniforms also helped families "save money," as well as served as an "equalizer" for students of different social classes to feel more alike in their school day. ${ }^{479}$ Kammen often emphasized the American dilemma of "how to glorify progress without minimizing the past? How to celebrate tradition without neglecting the wonders of the present?" 480 As Aquin faced technological advancements in society and within their own walls and financial donations that upgraded facilities, they held tight to particular traditions and norms and reintroduced some from decades long ago.

The support of Aquin “elder” Bishop O’Neill was evident, still, in 1990 when he agreed to sit atop the roof of Aquin for a day if the school community reached their sales goal for raffle "passbooks." ${ }^{481}$ Even after his passing in 2013, many Aquin adults still spoke of him with immense fondness. However, despite a scholarship in his name and the St. Thomas parish hall named in his honor, it is the impression of Kathy Runte that to Aquin students of 2014, he had largely become a name of the past. Sometimes the narratives of the particular philanthropists or mentors were lost to time, and sometimes they remained tangible to the students because of personal connections maintained by the family members. Legends tend to live to the degree to which they serve the current needs of a community.

The Mary Ledwith story, while not necessarily known by all of the active students, remained rich to anyone who heard it, ironically, because she was not well known to Aquinites during her lifetime. It was discussed earlier that as a matter of

\footnotetext{
${ }^{479}$ Hadjokas.

${ }^{480}$ Kammen, 279.

${ }^{481}$ Minutes Freeport Catholic School Board December 20, 1990, Aquin papers.
} 
service, Aquin students in the 1980s assisted residents at St. Vincent's with getting to daily mass. One of these elderly persons was Ms. Ledwith, who greatly appreciated daily mass and the help she received in getting there. ${ }^{482}$ A woman without children, and, unbeknownst to Aquin folks, of private wealth, she left to Aquin upon her death in 2002 a gift of nearly two million dollars. The principle is held by the diocese in a foundation fund, and the interest provides financial help to Aquin in amounts ranging from roughly $\$ 75,000$ to $\$ 150,000$ annually. ${ }^{483}$ In addition to providing Aquin some economic security, Ledwith added to Aquin's oral tradition a parable on the merits of community service.

Through the 1990s and the first decade of the twenty-first century, Aquin educated a bit over $6.7 \%$ of students in the City of Freeport. By 1999-2000, that percentage had grown to 7.1, by 2004-2005 it grew further to 7.7\%, and by 2013-2014, Aquin served $8.2 \%$ of Freeport's kids. ${ }^{484}$ Nationally, in 1999-2000 4.8 percent of schoolage children were educated in Catholic schools, whereas, Aquin Catholic Schools (K-12) enrolled a significantly higher rate of students. ${ }^{485}$ The percentage increase was likely attributable to Freeport families fleeing what they perceived as an undesirable environment in the public schools. According to long-time Freeporter and coordinator for AVID in the public schools, George Buss reflected that there was a greater number of Freeport students in poverty by 2014 , and, as can be common for persons in poverty, many of them faced difficult family situations. ${ }^{486}$ A telling anecdote is that the rate of students at FHS receiving "free and reduced lunch" due to income status lept from 26\%

482 Cieslak.

483 Ibid; Runte.

${ }^{484}$ Freeport School District 145 annual District Staff Directories, FSD 145 papers; Valkema; Runte.

485 “Issues A-Z: Private Schooling," Editorial Projects in Education Research Center, Education Week. (August 4, 2004). http://www.edweek.org/ew/issues/private-schooling/ (accessed May 18, 2014); Runte. ${ }^{486}$ Buss. 
in the mid-1970s and 1980 s to a 2014 metric of $86 \%{ }^{487}$ He elaborated that while there may have been a greater number of students at FHS who displayed "a lack of traditional school manners," the schools were safe and there were "relatively few kids who acted up." ${ }^{488}$ Buss clarified that while he found the public school professionals to be doing a good job, there was, nonetheless, a perception by some people in town that there was less disciplinary control than there once had been. ${ }^{489}$ He advocated for the good work being done by FHS for a struggling population and expressed understanding for the change in town demographics.

Aquin's general environment of structure and expectations for respectful behavior seemed to have proven a great asset for some families in Freeport. Recall Buss' earlier commentary that while Aquin had previously (1970s) been viewed only as a religious school, by the 1990s it became, in Freeporters' minds, an academic alternative to the public system. ${ }^{490}$ Recall, also, that the Finches, with a combined fifty years of public school service, noted previously that Aquin families were predominantly middle class and desired a small school environment with high expectations. ${ }^{491}$ While the Finches occasionally encountered perceptions by their public school colleagues that Aquinites were elitist, they insisted that Aquin families were simply proud of what they could

\footnotetext{
487 Ibid. Recall that it was in the 1990s when large numbers of white-collar management professionals left Freeport's Honeywell company for Minneapolis, MN.

488 Ibid.

489 Ibid.

490 Ibid.

${ }^{491}$ Dr. Edward Finch; Cathy Finch. In addition to Edward's role as HS teacher and, later, as Director of the Stephenson County Historical Society, he served, also, as President for Freeport's Lincoln-Douglas Society and taught courses at Highland Community College in Freeport and Rock Valley College in Rockford. In addition to administrative roles at Freeport, Dakota, Winnebago, and Stockton high schools, Cathy was also on the Board of Directors for the Illinois High School Association (I.H.S.A.), and later served as Assistant Superintendent for the Stephenson County Regional Office of Education (R.O.E.).
} 
accomplish with so few resources, and they contended that Aquin welcomed everyone. ${ }^{492}$ Whereas a white flight seemed to have been absent within Freeport's history, there appeared later to have been a socioeconomic wandering, to a small degree, from FHS up the road to AHS as some families (at least partly middle class) transferred their students to the Catholic High School. ${ }^{493}$

Those increasing attendance percentages, however, were based on a decreasing total number of children in the town, and thus, actual enrollment numbers at Aquin could pose problematic for school programs. Relative to the peak in student numbers in 19691970, the City of Freeport had lost approximately 34 percent of its high school aged students by 2013-2014. ${ }^{494}$ Aquin alum and board member, and long-time Freeporter, Tim Smith, lamented that "Freeport's a hurting town." the related closing of local factories), the bypass that took travelers around, rather than through town, and rental properties comprising $38 \%$ of Freeport housing, the town was seeing a shift in demographics and a downward spiral of economic conditions. ${ }^{496}$ Smith and others felt a looming and real possibility of more serious decline, as Met Life was closing in Freeport, as well, and he estimated the payroll loss to the immediate area could “approach \$15 million."497 As he said, "that's staggering."

The story of Aquin High School may have unfolded differently than other case studies of American Catholic schools, but Freeport and all of its schools have been affected by global, national, and state trends. Historian Roger Biles characterized Illinois

\footnotetext{
492 Ibid.

${ }^{493}$ Enrollment data, Aquin papers; Rich Chang, telephone interview by author, May 17, 2014. Retired from Accenture Consulting, Chang moved his family from the Chicago suburbs to Freeport and, as an Aquin alum, parent, coach, and philanthropist, he has worked on strategic planning for the school. 494 Buss.

495 Smith.

${ }^{496}$ Smith.

497 Ibid.
} 
as "a continental crossroads that for centuries has welcomed waves of immigrants" and "has been no stranger in the past to broad cultural and social transformations." $" 498 \mathrm{He}$ projected that "an increasingly diverse population will place greater demands on a public education system already facing significant challenges and hamstrung by the lack of resources."499 Nine years later, in 2014, journalist Greg Hinz claimed that "Illinois is far and away in worse shape than any other state in the country."500 Regardless of one's political assessment, the state finances in Illinois were not in good shape. Furthermore, the greatest hope for improving "significantly" the fiscal outlook appeared to rely on the “courts (upholding) a pension overhaul passed by the Legislature," a solution that would impact public employees, including public school teachers, and bear the risk of indirect, adverse effects in education. ${ }^{501}$

Father David Beauvais specified that there were "fewer middle class families in the United States" today than in the past, and "Freeport is an exemplar of that." 502 Eric Zuesse of the Huffington Post reported in December of 2013 that of the "top 20 developed nations" in the world, "the U.S. has the most extreme wealth-concentration of them all." ${ }^{503}$ He reported the findings from the Credit Suisse Global Wealth Databook of 2013 that "in the U.S. $75.4 \%$ of all wealth is owned by the richest $10 \%$ of the people," and these numbers put the United States on par for wealth equality (or inequality) with

\footnotetext{
498 Biles, 306.

499 Ibid.

${ }^{500}$ Greg Hinze, "State in Deepest Financial Hole Ever," http://www.chicagobusiness.com/article/ 20140313/BLOGS02/140319866/state-in-deepest-financial-hole-ever (accessed June 15, 2014).

501 lbid.

502 Beauvais.

${ }^{503}$ Eric Zuesse, "United States is Now the Most Unequal of All Advanced Economies," Huffington Post (December 8, 2013). http://www.huffingtonpost.com/eric-zeusse/us-is-now-the-mostunequa_b_4408647.html (accessed June 16, 2014).
} 
Chile, India, Indonesia, and South Africa. ${ }^{504}$ With tight economic times for many families as well as continual news reports of an overall gloomy financial forecast, it may have been difficult for American families to afford, or to justify paying, the tuition and fees for private education. According to a 2004 article in Education Week, "on average, private school students come from families with higher incomes than those of public school families." Private High School Attendance," in which he claimed that "private school enrollment decisions are relatively insensitive to tuition and fees levels." ${ }^{\text {506 }}$ Yet, he also elaborated that "family income, tastes for private schooling, private school access, and public school quality are all important determinants of the private school attendance decision." ${ }^{, 507}$

Thus, while an increase in tuition and fees may not affect enrollment numbers appreciably in terms of national trends, one could speculate that a change in a family's income may affect their individual ability to afford tuition, let alone increasing tuition. At a school like Aquin, with only around one hundred students, a handful of families on the financial bubble could easily become a significant loss for already small school programs. Furthermore, in terms of the social justice mission of the Catholic Church, economic conditions could pose challenges to serving those of less financial means who desire a Catholic education.

The early days of Catholic education saw an emphasis on the preservation of the Catholic faith in a country often hostile to Roman Catholicism and its Papal hierarchy, on the assimilation of poor, immigrant Catholics into American culture, economic security

\footnotetext{
504 Ibid.

505 Education Week, "Private Schooling," Education Week, August 4, 2004 http://www.edweek.org/ew/issues/private-schooling/ (accessed May 18, 2014).

506 John. Z. Smith Jr., "The Determinants of Private High School Attendance," Vassar College Working Paper No. 35, Vassar College, Department of Economics: May 1996.

507 John Z. Smith, Jr.
} 
and social status, and on the comfort provided by ethnic Catholic communities. Later, integrated Catholic citizens of the post-war, Vatican II era emphasized social justice, spiritual development, and ecumenicalism as well as academic achievement while some also maintained their Catholic school communities. A 2006 Aquin Junior-Senior High School brochure, "The Little School that Can," emphasized "high academic standards" and behavioral expectations as well as made clear the continued focus on daily prayer, seasonal liturgical ceremonies and masses and hours of community service. ${ }^{508}$ In 2014 , the fiftieth anniversary of the Second Vatican Council, Aquin's internet home page opened with the headline "AQUIN: Cultivating the Spirit. Empowering the Mind," and the mission of Aquin Catholic Schools outlined "Who We Are." Here are a few examples:

We welcome new members to Aquin by reaching out to students, parents and teachers who have chosen to join us. We foster a commitment to service in our children as they design and implement numerous service projects in the community. We are parents who are willing to sacrifice to give our children an education in a faithfilled learning environment. We work to eradicate any signs of exclusion or isolation in our student body. We learn how to resist bullying, to learn from our mistakes, and to speak up against injustice. We acknowledge and treasure the value of the Aquin experience. ${ }^{509}$

Aquin students of 2014 were part of a new network, the Highland Community College Servant Leadership Program, in which they "collaborate with students from other schools" and of various faiths to plan and implement local awareness and fundraising events benefitting diverse needs in the town. ${ }^{510}$

As argued earlier, the leverage Catholic schools had for upholding their locallyderived honor codes empowered them to create and maintain more easily strict

\footnotetext{
${ }^{508}$ The Little School That Can brochure, Aquin Junior-Senior High School, 2006, Aquin papers.

509 http://www.aquinschools.org (accessed May 12, 2014).

${ }^{510}$ Runte.
} 
environments than could the public schools. However, what a school community created with this authority was significant. Bryk, Lee, and Holland pointed to the trend in Catholic schools as using their power to hold students accountable to high expectations, and they also made clear the preponderance of Catholic school teachers investing themselves in the well-being of their students. ${ }^{511}$ It stands to reason that such sacrifice was often reciprocated by students who felt a sense of personal accountability to these elders. This environment was a valuable asset to a community, as it provided for families a choice in education.

Mindy Borgmann, a fourth generation "Freeporter" who lived or worked in Freeport nearly all of her life, and whose children attended public schools, shared her shifting perceptions of Aquin. A 1982 graduate of nearby Dakota High School, Borgmann had been under the impression as a teen that Aquin was where people with money went to school. ${ }^{512}$ Over the years of social media connectivity and area-wide club sports, she, and many people in her family, had gotten to know Aquin folks and have come to realize that they are not, after all, elite nor elitist. ${ }^{513}$ In fact she knows a family without exceptional financial means who scrimped and saved to make it possible for their son to attend Aquin simply because he had struggled in his small, reputable public school and they believed Aquin might be his saving grace. ${ }^{514}$ According to Borgmann, the Aquin school community was working wonders for him. Her own daughters graduated from Dakota (public) High School, just ten miles northeast of Freeport, but her opinion of

\footnotetext{
511 Bryk, Lee, and Holland, 97, 99-100, 127-128, 133-134, and 305.

512 Mindy Borgmann, interview by author, June 3, 2014.

513 lbid.

514 Ibid.
} 
Aquin's role in the greater Freeport area changed positively since she had gotten to know more of the people from the Catholic school. ${ }^{515}$

It appeared that a Catholic school was the right fit for some students. Yet, conversation with several families in Freeport over decades of time revealed that some students left Aquin due to personal conflicts or school politics, and others simply because they sought more diverse instructional or extracurricular opportunities. For a few kids, it was a matter of a particular child having more of a "big school" personality, and a school as small as Aquin felt confining to him or to her. To explore the question of whether or not these issues translated to the national scene would be a relevant project, as the concept of "choice" inherently implies that any one type of school, such as a generally excellent, small, Catholic school, was not the right place for every student.

A school like Aquin, with its tight-knit tribal environment, rich in tradition and legends, and supported by personally-invested elders offered what Catholic scholar and philosopher Father Richard Rohr described as a "strong container" for the "first half of life" in which clear boundaries were drawn, norms and values taught, and a foundation was established for a person to learn who they were. ${ }^{516}$ This, too, held a challenge. While Father Rohr argued that a solid sense of self within his or her community's system of codes was critical if one was to be adequately prepared to move into the "second half of life," moving on to that next part was, indeed, the purpose of it all, and breaking from the tribe to grow in the ambiguity of the larger world was difficult. ${ }^{517}$ He taught the ideal life journey as one of "order," but followed by an adult period of "disorder," and

\footnotetext{
515 Ibid.

${ }^{516}$ Richard Rohr, Falling Upward: A Spirituality for the Two Halves of Life. (San Francisco: Jossey-Bass A Wiley Imprint, 2011).

${ }^{517}$ Ibid.
} 
hopefully, an eventual culmination in a "synthesis" that fueled an informed sense of the common good extending beyond one's own ego, family, and tribe. ${ }^{518}$ How might such a community manage successfully this necessary tension between providing roots and encouraging wings? Moreover, how might the school maintain its sense of history and tradition while embracing within its own walls yet another era of change?

Scholar Carol Ann MacGregor argued in 2014 that "Catholic education could be especially important as the Hispanic population continued to increase. Most Latinos were at least nominally Catholic, and research has documented that their children often fall short in learning outcomes." ${ }^{519}$ Historian John T. McGreevy claimed that the newest immigrants "reminded now affluent Euro-American Catholics of their own history, and provided an unusual opportunity for contact across class lines of class and ethnicity.",520 Freeport saw a growth in the Hispanic population from approximately 2-3\% of the public school student population in the 1990s to roughly 5-7\% between 2000 and 2014 as their families came to town for work in metal fabrication or manual, independent labor. ${ }^{521}$ Sister Joella Miller shared that she and Bishop O’Neill "hoped always that there could be money in the Aquin budget to take in children without financial means, that no one would be refused." ${ }^{522}$ In Parish School, Timothy Walch referred to the choice Catholic schools provided to students of poorer neighborhoods when he asserted that parochial schools

\footnotetext{
${ }^{518}$ Richard Rohr, "The First Half of Life," Email to Center for Action and Contemplation mailing list, March 2, 2014. (http://myemail.constantcontact.com/Richard-Rohr-s-Meditation-Scripture-as-Template-forDevelopment.html?soid=1103098668616\&aid=ZMGLlySGKOg.

${ }^{519}$ Carol Ann MacGregor, "Why the Decline of Catholic Schools Matters," Scholars Strategy Network, http://www.scholarsstrategynetwork.org/sites/default/files/ssn_key_findings_macgregor_on_the_declin e_of_Catholic_schools.pdf (accessed May 18, 2014).

${ }^{520}$ McGreevy, 262.

${ }^{521}$ Buss.

${ }^{522}$ Sister Joella Miller.
} 
"constitute one of the primary places where the Catholic Church can give Christian service. ${ }^{, 523}$

John B. Huber offered in his 2007 study of "The Accessibility of American Catholic Secondary Schools to The Various Socioeconomic Classes of Catholic Families," that "Catholic high school tuition has risen steadily at a rate consistently higher than both family income increases and the rate of inflation. ${ }^{, 524} \mathrm{He}$ argued that while "Sociologist Greeley" pointed out "that financial aid has increased significantly," the national "percentage of children from working class and middle class families in Catholic schools is declining." ${ }^{.525}$ All schools in his study "reported that they cannot fully meet the needs of those who apply for aid," even though "a majority of families earning less than $\$ 70,000$ a year reported receiving" some "financial aid," with "the average grant" awarded at "less than half the yearly tuition price." ${ }^{.526}$ Additionally, many parents were not aware of the "extent to which aid was available" and "had the perception" it "was available solely to those of very low incomes." ${ }^{, 527}$ Affordability continued to be a concern for leadership at Aquin, and they launched the "Guardian Angel" fund by which alums and other "friends of Aquin" could contribute to help finance scholarships for students in financial need. ${ }^{528}$ One might question if an increase in the number of low income students at a rural Catholic school, such as Aquin, would negatively affect its attractiveness to middle class families. The unique leverage of private schools to enforce their strict codes of conduct makes it plausible for Catholic schools to maintain a calm, studious environment whereas public schools have far less leverage for such honor codes.

\footnotetext{
${ }^{523}$ Walch, 84.

${ }^{524}$ Huber, 271-287.

525 Ibid.

526 Ibid.

527 Ibid.

${ }^{528}$ Runte.
} 
In private schools, there was a greater chance of incoming students adapting to the established norms and expectations of the school community.

Huber's study found that "strong academics, Catholic tradition and philosophy, Christian values, discipline, safe environment," and "their child's preference" were the most significant reasons families chose a Catholic school for their child's education. ${ }^{529}$ Walch's argument about high expectations held by Catholic schools fit nicely with Huber's findings. ${ }^{530}$ Walch highlighted that what was of particular importance in the Catholic school setting "was the environment" in which teachers "expected results from their students," and he quoted "one Catholic teacher, 'The important thing is to make children believe in themselves, and you can’t do it by coddling them." ${ }^{, 531}$ Bryk, Lee, and Holland described the Catholic schools' approach as "the formation of each student as a person-in-community," and they claimed this to be the "central educational aim of these schools." ${ }^{532}$ They added that "if they are to teach children how they should live in common, they must themselves be communities. The school must be a microcosm of the society - not as it is, but as it should be . . . socially, ethnically, and (even) religiously" diverse. ${ }^{533}$ They argued that the "cohering force" within the school communities is not predicated on "likemindedness," but on "the tradition of these schools." 534

Sixty years of post-war cultural change and having weathered the 1970s and 1980s decline in enrollment and a span of spotty fiscal management, Aquin found itself in a new era of post-industrial globalization for which a new strategic plan was necessary. Hadjokas thought aloud that, as time went on, it seemed that the monied folks did not

\footnotetext{
${ }^{529}$ Huber.

${ }^{530}$ Walch, 238.

531 Ibid.

${ }^{532}$ Bryk, Lee, and Holland, 289.

533 Ibid.

534 Ibid.
} 
"outnumber" those with less financial means, but that they may have possibly become "louder." ${ }^{, 35}$ She felt sure that any change that had transpired at Aquin was likely due to "a generational thing" by which people in 2014 had less time to volunteer at schools because it had become normative to have "two-income families." parents may have had "more money to give . . . or maybe not enough money, even.",537 The challenges Aquin faced in that new era were in some ways different, and complicated. Walch quoted former president of the Catholic University of America, William J. Byron, "We as a nation are now more than ever possessed by our possessions," and Walch added that "greed, promoted by popular culture, is on the rise, and sacrifice . . . is on the decline." ${ }^{, 538}$ Walch's research, however, also indicated another modern trend toward a "new American Catholic family" that "is often a single parent with one or two children" who "no longer have the time or energy to contribute to the operation and maintenance" of a school. ${ }^{539}$ One could readily attribute the declining numbers of students in the Aquin Catholic Schools to the national and state economies and a shift in local demographics. That such factors were having a significant impact on the school system necessitated more than ever regular and careful assessment to navigate purposefully the tension between internal traditions and faith-based outreach.

To make Catholic schooling affordable to Latino families who were represented disproportionately in poverty statistics, MacGregor suggested taking a close look at financial models like that of Cristo Rey in which students 'work one day a week for a

\footnotetext{
535 Hadjokas.

536 lbid.

537 Ibid.

${ }^{538}$ Walch, 242.

539 Ibid.
} 
business or non-profit organizations that, in turn, cover their tuition." ${ }^{540}$ Father Beauvais stated that his experience in the Rockford churches made clear to him that "Hispanics would love to send their kids to Catholic schools, but many can't afford it.." ${ }^{, 51}$ Huber suggested building endowment funds dedicated solely for financial aid to students in need, to "petition Catholics of higher incomes to sponsor the Catholic education of children" of lesser means, and create strong relationships with alumni who could "give back to the schools that in many ways formed them.. ${ }^{542}$ Beauvais also shared that some students in Rockford were able to attend Catholic school only because their grandparents helped pay their tuition, but for many students, this was not possible. ${ }^{543}$ Historian James M. O'Toole added, "these 'Catholics of color' will reconnect the church to its roots among the poor and the working class," but this came at a difficult time when Catholics were faced with "the emotional pull of personal ties to ancestral parishes" as they attempted to balance this with the "hard-headed realities of keeping the buildings open and in good repair." ${ }^{544}$

After lamenting the dark economic forecast ahead for the City of Freeport and Aquin Catholic Schools, Tim Smith said with resolve, "Aquin, it's like a Phoenix," which rises up new after death. ${ }^{54} \mathrm{He}$ continued on, sharing that "there's a lot of pride up there," and he provided a substantial anecdote of his perceived value of the school, "Father Bolger's Religion class is my grandson's favorite. He's a sophomore and talks about their spiritual discussions all the time." ${ }^{546}$ Smith further underscored why Aquin

\footnotetext{
${ }^{540}$ Runte.

${ }^{541}$ Beauvais.

${ }^{542}$ Huber.

${ }^{543}$ Beauvais.

${ }^{544}$ O'Toole, The Faithful, 267.

${ }^{545}$ Smith.

${ }^{546}$ Smith.
} 
should survive in sharing that each year, as he and his wife read the scholarship applications for the memorial they established in their son, Colby's, name, that they are moved to tears to read adolescents' writings about their personal hardships and family struggles through which Aquin provided a sense of security and support. ${ }^{547}$

Local control of the educational system and processes seemed pivotal to creating that sort of environment. Education scholars Wayne J. Urban and Jennings L. Wagoner, Jr., in their survey text of American education, have explicated the benefits and the disadvantages of decentralized education, or local control. ${ }^{548}$ The 1980 s school reform that shifted "regulatory power from the federal to the state level of government" failed to "lesson the flow of regulations," as state departments of education imposed plenty of "arbitrarily fixed mandates." 549 This continued into the 1990s, and "regulatory activity may well have (even) increased."550 That "our constitution makes education a function of the states, not of the federal government" made these issues political trigger points. ${ }^{551}$ Yet, state control and less interference from the federal government seemed not to have lessened the burden in America's classrooms. With the federal initiatives No Child Left Behind (NCLB, 2001) and Race to the Top (2009), there was a shift back toward centralized control.

To the other extreme, a reform movement for decentralization in the late 1980s emphasized decision-making on the most local level - by parents, teachers, and students. ${ }^{552}$ Success in environments with that degree of local control was predicated on

\footnotetext{
547 Ibid.

${ }^{548}$ Urban and Wagoner.

549 Ibid., 88, 328.

550 lbid., 328.

551 Ibid., 329.

552 Urban and Wagoner, 329.
} 
the effective leadership of "the local school administrator." 553 Thus, in one district, or in one school building, one might find excellent instruction and inclusive services provided for all the diverse students; yet, in another building, far less success might be found. Additionally, many parents found it difficult "to be available for wide-ranging consultations," and many teachers "resented time taken away from instruction and instructional planning" in order to collaborate on administrative matters. ${ }^{554}$ However, more local control, rather than less, according to Urban and Wagoner, was more likely to create "substantially meaningful changes," because, as they claimed, "federal accountability standards as well as state mandates" sometimes layered onto schools "actual restraints" that impaired teachers from "reacting to the particular needs and interests of their students." "A55 "A steady diet of standardized testing and judgment of the merit of public schools on the basis of those test scores" showed "little real promise to improve American education significantly.",556

The Common Core State Standards (CCSS) "represent the same subjects that have narrowed the curriculum through the testing mandates of NCLB and like-minded policies." 557 That the aim of the standards was to "try to continue the movement to improve the academic content taught in schools," however, they provided valuable goals for curriculum development. ${ }^{558}$ Urban and Wagoner concluded, "The stakes are too high intellectually in our time to allow schools to become either factories for manufacturing test results or play pens where children and youth fulfill their immediate needs as they

\footnotetext{
553 Ibid.

554 Ibid.

555 Ibid., 333.

556 lbid., 350.

557 Ibid., 357.

${ }^{558}$ Urban and Wagoner, 357.
} 
themselves define them." 559 Having external references, indicators, and networks could assist educators in gauging the relevancy and rigor of their instruction as much as context anchors an historian's particular narrative. Aquin maintained its "autonomy," while "adopting the principles of critical thinking, student engagement, and student accountability."560 Their implementation of CCSS was not beholden to state and national mandates, and so, they were free to finesse the details with reasonable autonomy. ${ }^{561}$ As offered previously, education scholar Neil McCluskey argued in 1968 for local (parental) control of their children's education while recognizing the necessary attunement to advances in academic methods in the public sector. ${ }^{562}$ In her role at the Stephenson County ROE, Cathy Finch, saw an increase in academic rigor at Aquin due, perhaps, to newer sets of standards. ${ }^{563}$ Balancing a connection to a centralized network with local autonomy, however, was key if administrators and teachers were to sidestep bureaucratic inefficiencies and generalized, ill-fitting policies and programs. It was critical to maintaining a healthy tension between state, national, and global norms and advancements on one hand and discernment of local needs on the other. Aquin had a principled, forward-looking mission as well as dedicated elders who made sure that no child was left behind -- even before it was vogue. A collaborative plan that would preserve and support such elders and the critical roles they played in positive, tandem with gifted, interested parents and alums could place Aquin in a proactive state of managing their school community and securing a future of serving the common good.

\footnotetext{
559 Ibid., 369.

560 lbid.

${ }^{561}$ Runte.

562 McCluskey, 25-26.

${ }^{563}$ Cathy Finch.
} 
Walch claimed that "foremost among the qualities of parish-based education is decentralization," because "parents have a greater involvement and effectiveness in the education process," and "parents, students, and faculty share a broad set of beliefs that give each school a moral purpose." $"$ W64 Walch went further to state that with "little prospect for public aid and only a modest prospect of outside funds, it is clear that the future of Catholic parochial education will be determined by the parents of the children who are educated in these schools. ${ }^{, 565}$ Their presence, participation, and the plans they created were what constituted "Aquin." Aquin and its challenges were metaphor for the contradictory and simultaneous stability and tumult of the Catholic Church at large. ${ }^{566}$

Providing an anchor, or perhaps a lighthouse, by which some Catholic Freeporters weathered the storm of post-war cultural and Catholic changes, Aquin was a case study that exemplified Kammen's claim that "men and women" looked "to the past for guidance and comfort because they felt ill at ease with the transitional character of their own time. Moving from an outworn past into an unknown future, they wished to believe that understanding the past would enable (or at least assist) them in locating, and perhaps even in preserving their proper place along the continuum of time. ${ }^{.567} \mathrm{He}$ underscored the "anxious mood of the 1950s" and the "wistful nostalgia" in the 1970s and 1980s, indicating that World War II "brought a pronounced sense of discontinuity between past and present" because of which "many Americans managed to create" for themselves "selective presentations of" the past. ${ }^{568}$ Then, as later, the folks at Aquin proclaimed, "We Are Aquin," as they insisted on forging an empowered, communal identity. Even to

\footnotetext{
${ }^{564}$ Walch, 244.

565 Ibid., 246.

${ }^{566}$ McGreevy, 293.

${ }^{567}$ Kammen, 282.

568 Ibid, 533-534.
} 
a greater degree than most private institutions, Aquin enjoyed autonomy in the running of its school, and Freeport was unencumbered by the race-related tensions that were typical of many American schools in the 1970s and 1980s. Yet, the history of this peculiar, rural Catholic school still followed many Catholic school trends emphasized in previous scholarship. It was also quintessentially American, by Kammen's definition, in that it worked to maintain a practical tension between conflicting values, most notably those of progress and tradition. ${ }^{569}$ This novel case study, therefore, offers clear, powerful support for the conclusions drawn previously by scholars.

In the spirit of post-Vatican II ecumenicalism and Aquin's claim to working class roots and tradition, we borrow this quote, as did Kammen, from the founder of Hasidic Judaism, Ba'al Shem Tov: "Forgetfulness leads to exile, while remembrance is the secret of redemption." ${ }^{, 570}$ Remembrance is about connecting our useful perceptions of the past and our individual needs in the present to those of our neighbors. As we weave our narratives, we create the very communities by which we define ourselves.

\footnotetext{
${ }^{569}$ Kammen.

570 Ibid., 704.
} 


\section{REFERENCES}

\section{ORAL HISTORY INTERVIEWS}

Beauvais, Father David, interview by author, Rockford, IL, February 19, 2014.

Borgmann, Mindy, telephone interview by author, June 3, 2014.

Buss, George, telephone interview by author, May 23, 2014.

Chang, Rich, telephone interview by author, May 17, 2014.

Cieslak, Michael, telephone interview by author, February 25, 2014.

Finch, Cathy, interview by author, Freeport, IL, February 18, 2014.

Finch, Dr. Edward, interview by author, Freeport, IL, January 31, 2013.

Hadjokas, Kay, interview by author, Freeport, IL, January 18, 2014.

Miller, Sister Joella, telephone interview by author, March 17, 2014.

Pospischil, Bill, interview by author, Freeport, IL, February 19, 2014.

Runte, Kathy, email interview by author, February 4, 2014.

Smith, Tim, interview by author, Freeport, IL, January 18, 2014.

\section{PRIMARY SOURCES}

Aquin Catholic Schools. http://www.aquinschools.org/history.cfm. (accessed March 18, 2014).

Aquin Central Catholic High School Papers. Private collection.

Aquin Central Catholic High School Papers. Office of the Diocese of Rockford, IL. 
Barry, Dan. "Boomers Hit New Self-Absorption Milestone: Age 65." The New York Times. http://www.nytimes.com/2011/01/01/us/01boomers.html?pagewanted=all \&_r=0, December 31, 2010. (accessed April 10, 2014).

Blum, Virgil C., S.J. Catholic Education: Survival or Demise? Chicago: Argus Communications, Co., 1969.

Carroll, Patricia. The History of St. Mary's Catholic Church, Freeport, Illinois: 150 Years of Faith 1846-1996. Freeport, IL: Freeport Wagner Printing Co, 1996.

Campbell, Rev. Robert, O.P. Spectrum of Catholic Attitudes. Milwaukee: The Bruce Publishing Company, 1969.

Census Quick Facts. http://quickfacts.census.gov/ (accessed March 17, 2014).

“Diocesan Standards.” Diocese of Rockford, 1990.

Easton, Laurine M., William F. Easton, and Msgr. David Kagan. The Diocese of Rockford 1908-2008. Strasbourg, France: Editions du Signe, 2007.

Education Week. "Issues A-Z: Private Schooling," Editorial Projects in Education Research Center, Education Week (August 4, 2004). http://www.edweek.org/ ew/issues/private-schooling/ (accessed May 18, 2014).

Eggers, Dave. What is the What: The Autobiography of Valentino Achak Deng, A Novel. San Francisco: McSweeney's, 2006.

Freeport School District. "Freeport High School." http://www.freeportschooldistrict.com/ domain/108. (accessed March 17, 2014).

Freeport Public Schools papers. Freeport Public Schools Unit Office.

Gillespie, Danielle. "Bid to Unionize Pits Job Security Against Mission of Catholic School.” CNS News (2008). http://cnsnews.com/news/article/bid-unionize-pitsjob-security-against- mission-catholic-school (accessed February 22, 2014).

Glink, Steven E. "Protecting the rights of students, parents, and teachers." http://www.educationsrights.com/studentsrights.php (accessed May 18, 2014).

Golden Jubilee Souvenir: The History of Catholicity in Stephenson County, IL. 1896.

Grimsson, President Olafur. "2013 Global Leadership Summit.” London Business School (May 23, 2013). http://lgls.london.edu. (accessed April 21, 2014).

Hinze, Greg. "State in Deepest Financial Hole Ever." ChicagoBusiness.com (March 13, 2014). http://www.chicagobusiness.com/article.20140313/BLOGS02/140319866/ state-in-deepest-financial-hole-ever. (accessed June 15, 2014). 
Honeywell Retiree Club of Arizona. "Honeywell History." http://www.hrcaz.org. (accessed April 8, 2014).

Ihrke, David K. and Carol S. Faber. "Geographical Mobility: 2005 to 2010.” U.S. Department of Commerce Economics and Statistics Administration of the U.S. Census Bureau http://www.census.gov/hhes./migration (accessed May 18, 2014).

Lethlean, Jane. “Aquin Prom Draw Steeped in Tradition.” Journal Standard. (March 30, 2012). http://www.journalstandard.com/x760609986/Aquin-Prom-Draw-Steepedin-tradition_(accessed March 30, 2014).

MacGregor, Carol Ann, "Why the Decline of Catholic Schools Matters," Scholars Strategy Network. http://www.scholarsstrategynetwork.org/sites/default/files/ssn_ key_findings_macgregor_on_the_decline_of_Catholic_schools.pdf (accessed $18,2014)$.

McCluskey, Neil G., S.J. Catholic Education Faces Its Future: The Background, Present Position, and Future Trends of Catholic Education. New York: Doubleday \& Company, Inc., 1969.

McDowell, Reverend John B. Catholic Schools, Public Education, and American Culture. Huntingdon, IN: Our Sunday Visitor Publishing Division, 2000.

Miller, Reverend Robert R. That All May Be One: A History of the Rockford Diocese. Rockford: The Diocese of Rockford, 1976.

Miller, Reverend Robert R. “The Most Reverend Arthur J. O'Neill,” Diocese of Rockford. http://www.rockforddiocese.org/Bishop-ONeill (accessed March 24, 2014).

National Catholic Education Association. "About Us.” National Catholic Education Association. http://ncea.org/about-us/catholic-education-information (accessed May 18, 2014).

National Catholic Education Association. "Data \& Information." National Catholic Education Association. http://www.ncea.org/data-information/catholic-schooldata (accessed June 12, 2014.)

"prom draw 2014 . my girl," YouTube video, 4:39, posted by "Laura Diemer," March 20, 2014, https://www.youtube.com/watch?v=Xq8v_JZ_C_A (accessed April 15, 2014).

Richter, Suzanne and Phil Rogers. "Bingo for Prom Dates." NBC6.com (July 12, 2009). http://www.nbcmiami.com/the-scene/archive/Aquin-Central-Catholic-HighSchool-Prom-Dates-Freeport-Illinois-Bingo-Dispenser-Stress.html. (accessed March 30, 2014). 
Rohr, Richard. Falling Upward: A Spirituality for the Two Halves of Life. San Francisco: Jossey-Bass A Wiley Imprint, 2011.

Rohr, Richard. "The First Half of Life." Email to Center for Action and Contemplation mailing list, March 2, 2014 http://myemail.constantcontact.com/Richard-Rohr-sMeditation-Scripture-as-Template-for-Development.html?soid=1103098668616\& aid=ZMGLJySGK0g

Shuster, George N. Catholic Education in a Changing World. Chicago: Holt, Rinehart and Winston, 1967.

Stephenson County Superintendent of Schools Annual Directories. 1965-1966 through 1982-1983.

U.S. Department of Education. National Center for Education Statistics. U.S. Department of Education. "Digest of Education Statistics." U.S. Department of Education http://nces.ed.gov. 1999. (accessed March 26, 2014).

Veritas, Aquin High School yearbooks.

Zeusse, Eric. "United States is Now the Most Unequal of All Advanced Economies." Huffington Post (December 8, 2013). http://www.huffingtonpost.com/ericzeusse/us-is-now-the-most-unequa_b_4408647.html (accessed June 16, 2014).

\section{SECONDARY SOURCES}

Appleby, R. Scott and Kathleen Sprows Cummings. Catholics in the American Century: Recasting Narratives of U.S. History. Ithaca: Cornell University Press, 2012.

Bailey, Beth. Sex in the Heartland. Cambridge, Massachusetts: Harvard University Press, 1999.

Biles, Roger. Illinois: A History of the Land and Its People. DeKalb: Northern Illinois University Press, 2005.

Bryk, Anthony S., Valerie E. Lee, and Peter B. Holland. Catholic Schools and the Common Good. Cambridge: Harvard University Press, 1993.

Buetow, Father Harold A., JD, Ph.D. A History of United States Catholic Schooling. NCEA Keynotes Series no. 2 Washington, DC: National Catholic Educational Association, 1985.

Formisano, Ronald P. Boston Against Busing: Race, Class, and Ethnicity in the 1960s and 1970s. Chapel Hill: The University of North Carolina Press, 1991. 
Greeley, Andrew M. and Peter H. Rossi. The Education of Catholic Americans. New York: Anchor Books, Doubleday \& Company, Inc., 1968.

Hartman, Andrew. Education and the Cold War: The Battle for the American School. New York: Palgrave MacMillan, 2008.

Heinlein, Lisa Melman and Marybeth Shinn. "School Mobility and Student Achievement in an Urban Setting." Psychology in the Schools, 37, no.4 (2000).

Huber, John B. "The Accessibility of American Catholic Secondary Schools to the Various Socioeconomic Classes of Catholic Families," Catholic Education: A Journal of Inquiry and Practice 10, no. 3 (2007): 271-287.

Hunt, Thomas C. and Timothy Walch. Urban Catholic Education: Tales of Twelve American Cities. Notre Dame, Indiana: Alliance for Catholic Education Press, 2010.

Kammen, Michael. Mystic Chords of Memory: the Transformation of Tradition in American Culture. (New York: Vintage Books a Division of Random House, Inc., 1991).

Kennedy, David M., Thomas A. Bailey, and Mel Piehl. The Brief American Pageant. Lexington, Massachusetts: D.C. Heath and Company, 1996.

Kruse, Kevin M. White Flight: Atlanta and the Making of Modern Conservatism. Princeton: Princeton University Press, 2005.

McDannell, Colleen. The Spirit of Vatican II: A History of Catholic Reform in America. New York: Basic Books, 2011.

McGreevy, John T. Catholicism and American Freedom: A History. New York: W.W. Norton \& Company, 2003.

McGreevy, John T. Parish Boundaries: The Catholic Encounter with Race in the Twentieth-Century Urban North. Chicago: University of Chicago Press, 1996.

Noraian, Monica Cousins. Women's Rights, Racial Segregation and Education from 1850-1920: the Case of Sarah Raymond, the First Female Superintendent. New York: Palgrave MacMillan, 2009.

O’Toole, James M. From Generation to Generation. Boston: Daughters of Saint Paul, 1983.

O'Toole, James M. The Faithful: A History of Catholics in America. Cambridge: The Belknap Press of Harvard University Press, 2008. 
Pemberton, William E. Exit with Honor: The Life and Presidency of Ronald Reagan. Armonk, New York: M.E. Sharpe, 1998.

Przygocki, W.F. "Teacher Retention in Catholic Schools," Catholic Education: A Journal of Inquiry and Practice 7, no. 4 (2004): 523-547.

Schulman, Bruce J. The Seventies: The Great Shift in American Culture, Society, and Politics. Cambridge: Da Capo Press, 2001.

Smith, John Z. Jr. "The Determinants of Private High School Attendance.” Vassar College Working Paper No. 35. Vassar College Department of Economics, 1996.

Stravinskas, Rev. Peter M.J. Constitutional Rights and Religious Prejudice: Catholic Education as the Battleground. Pine Beach, New Jersey: Newman House Press, 2009.

Stavrianos, L.S. Lifelines from Our Past: A New World History. New York: Pantheon Books, 1989.

Sullivan, Robert E. and James M. O'Toole. Catholic Boston: Studies in Religion and Community 1870-1970. Boston: Roman Catholic Archbishop of Boston, 1985.

Urban, Wayne J. and Jennings L. Wagoner, Jr. American Education: A History. New York: Routledge, 2014.

Walch, Timothy. Parish School: American Catholic Parochial Education from Colonial Times to the Present. New York: The Crossroad Publishing Company, 1996. 